In cooperation with the City of Houston

\title{
Groundwater Quality of the Gulf Coast Aquifer System, Houston, Texas, 2010
}

Data Series 598 



\section{Groundwater Quality of the Gulf Coast Aquifer System, Houston, Texas, 2010}

By Jeannette H. Oden, Dexter W. Brown, and Timothy D. Oden

In cooperation with the City of Houston

Data Series 598

U.S. Department of the Interior

U.S. Geological Survey 


\title{
U.S. Department of the Interior \\ KEN SALAZAR, Secretary \\ U.S. Geological Survey \\ Marcia K. McNutt, Director
}

\section{U.S. Geological Survey, Reston, Virginia: 2011}

\author{
This and other USGS information products are available at http://store.usgs.gov/ \\ U.S. Geological Survey \\ Box 25286, Denver Federal Center \\ Denver, CO 80225 \\ To learn about the USGS and its information products visit http://www.usgs.gov/ \\ 1-888-ASK-USGS
}

\begin{abstract}
Any use of trade, product, or firm names is for descriptive purposes only and does not imply endorsement by the U.S. Government.

Although this report is in the public domain, permission must be secured from the individual copyright owners to reproduce any copyrighted materials contained within this report.
\end{abstract}

Suggested citation:

Oden, J.H., Brown, D.W., and Oden, T.D., 2011, Groundwater quality of the Gulf Coast aquifer system, Houston, Texas, 2010: U.S. Geological Survey Data Series 598, 64 p. 


\section{Contents}

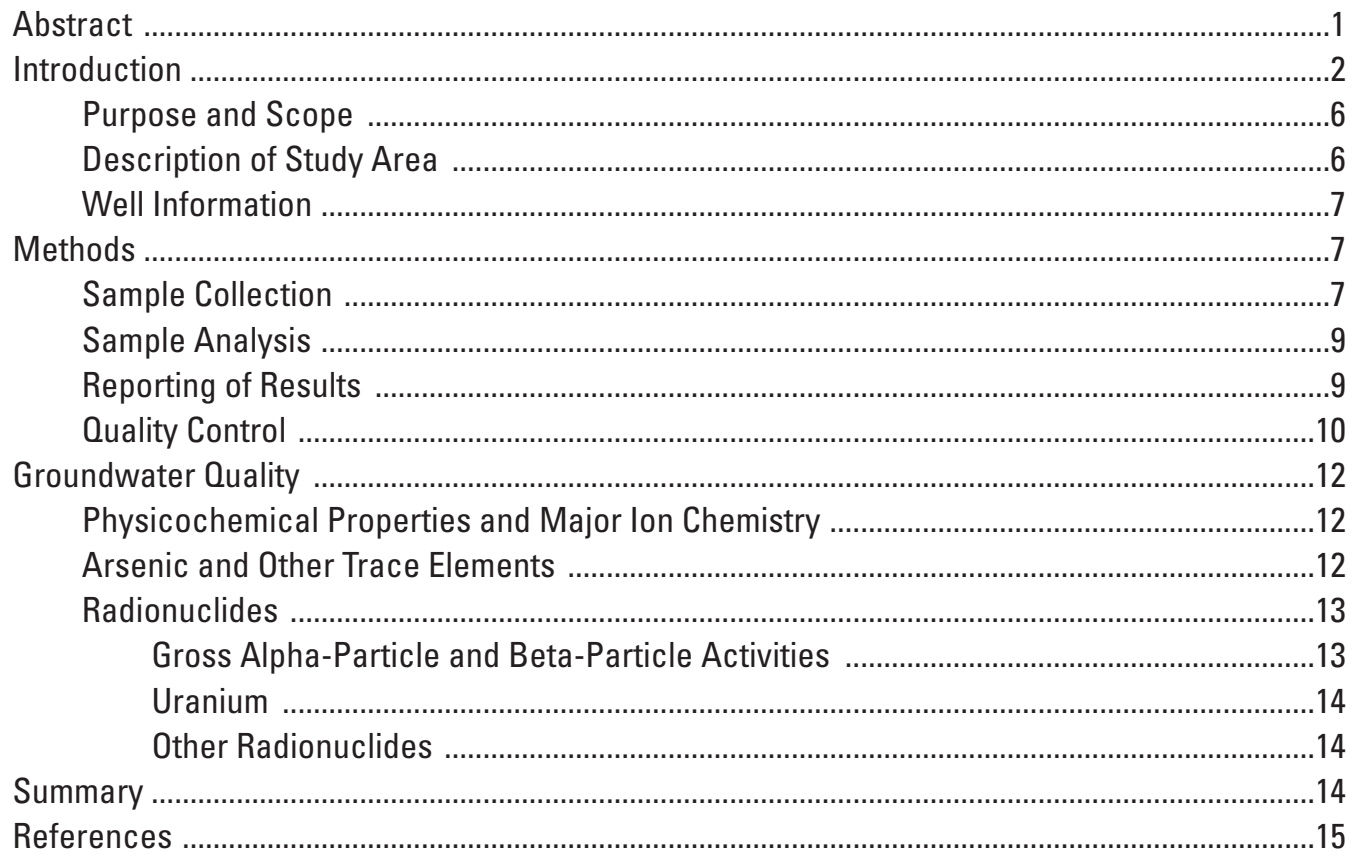

\section{Figures}

1. Location of 47 municipal supply wells in the Houston, Texas, area sampled during 2010

2. Diagram showing uranium-238 and thorium-232 radioactive decay series .....................4

3. Hydrogeologic section of the Gulf Coast aquifer system in Harris County and adjacent counties, Texas

\section{Tables}

1. U.S. Environmental Protection Agency maximum contaminant levels for arsenic and radionuclides in finished drinking water, February 2011 ........................................5

2. Well information for municipal supply wells sampled in the Houston, Texas, area, 2010

3. Results of major ion, trace element, and radionuclide analyses from qualitycontrol samples, equipment blanks, and field blanks collected in association with municipal supply wells sampled in the Houston, Texas, area, 2010 .

4. Physicochemical properties and results of major ions analyses in water samples collected from municipal supply wells in the Houston, Texas, area, 2010 .

5. Results of trace elements analyses of water samples collected from municipal supply wells in the Houston, Texas, area, 2010

6. Results of radionuclide analyses of water samples collected from municipal supply wells in the Houston, Texas, area, 2010

7. Relative percent differences (RPD) between sequential replicate and environmental samples analyzed for major ions, trace elements, and radionuclides and collected in association with municipal supply wells sampled in the Houston, Texas, area, 2010 


\section{Conversion Factors, and Datums}

\section{Inch/Pound to SI}

\begin{tabular}{lcl}
\hline \multicolumn{1}{c}{ Multiply } & By & \multicolumn{1}{c}{ To obtain } \\
\hline & Length & \\
\hline foot $(\mathrm{ft})$ & 0.3048 & meter $(\mathrm{m})$ \\
mile $(\mathrm{mi})$ & 1.609 & kilometer $(\mathrm{km})$ \\
\hline & Radioactivity & \\
\hline picocurie per liter $(\mathrm{pCi} / \mathrm{L})$ & 0.037 & becquerel per liter $(\mathrm{Bq} / \mathrm{L})$ \\
\hline
\end{tabular}

\section{SI to Inch/Pound}

\begin{tabular}{lcl}
\hline \multicolumn{1}{c}{ Multiply } & By & \multicolumn{1}{c}{ To obtain } \\
\hline nanometer $(\mathrm{nm})$ & Length & inch (in.) \\
micrometer $(\mu \mathrm{m})$ & $3.937 \times 10^{-8}$ & inch (in.) \\
millimeter $(\mathrm{mm})$ & $3.937 \times 10^{-5}$ & inch (in.) \\
kilometer $(\mathrm{km})$ & 0.03937 & mile (mi) \\
\hline & 0.6214 & \\
\hline microliter $(\mu \mathrm{L})$ & Volume & ounce, fluid (fl. oz) \\
milliliter $(\mathrm{mL})$ & $3.382 \times 10^{-5}$ & ounce, fluid (fl. oz) \\
liter $(\mathrm{L})$ & 0.03382 & ounce, fluid (fl. oz) \\
\hline & 33.82 & ounce, avoirdupois $(\mathrm{oz})$ \\
\hline gram $(\mathrm{g})$ & Mass & \\
\hline
\end{tabular}

Temperature in degrees Celsius $\left({ }^{\circ} \mathrm{C}\right)$ may be converted to degrees Fahrenheit $\left({ }^{\circ} \mathrm{F}\right)$ as follows:

$$
{ }^{\circ} \mathrm{F}=\left(1.8 \mathrm{x}^{\circ} \mathrm{C}\right)+32
$$

\section{Datums}

Vertical coordinate information is referenced to the National Geodetic Vertical Datum of 1929 (NGVD 29).

Horizontal coordinate information is referenced to the North American Datum of 1983 (NAD 83).

Specific conductance is given in microsiemens per centimeter at 25 degrees Celsius $(\mu \mathrm{S} / \mathrm{cm})$. Concentrations of chemical constituents in water are given in either milligrams per liter ( $\mathrm{mg} / \mathrm{L}$ ) or micrograms per liter ( $\mu \mathrm{g} / \mathrm{L})$ 


\title{
Groundwater Quality of the Gulf Coast Aquifer System, Houston, Texas, 2010
}

\author{
By Jeannette H. Oden, Dexter W. Brown, and Timothy D. Oden
}

\section{Abstract}

During March-December 2010, the U.S. Geological Survey, in cooperation with the city of Houston, collected source-water samples from 60 municipal supply wells in the Houston area. These data were collected as part of an ongoing study to determine concentrations, spatial extent, and associated geochemical conditions that might be conducive for mobility and transport of selected naturally occurring contaminants (selected trace elements and radionuclides) in the Gulf Coast aquifer system in the Houston area. In the summers of 2007 and 2008, a reconnaissance-level survey of these constituents in untreated water from 28 municipal supply wells was completed in the Houston area. Included in this report are the complete analytical results for 47 of the 60 samples collected in 2010 - those results which were received from the laboratories and reviewed by the authors as of December 31, 2010. All of the wells sampled were screened in the Gulf Coast aquifer system; 22 were screened entirely in the Evangeline aquifer, and the remaining 25 wells contained screened intervals that intersected both Evangeline and Chicot aquifers. The data documented in this report were collected as part of an ongoing study to characterize source-water-quality conditions in untreated groundwater prior to drinking-water treatment. An evaluation of contaminant occurrence in source water provides background information regarding the presence of a contaminant in the environment. Because source-water samples were collected prior to any treatment or blending that potentially could alter contaminant concentrations, the waterquality results documented by this report represent the quality of the source water, not the quality of finished drinking water provided to the public.

Samples were analyzed for major ions (calcium, magnesium, potassium, sodium, bromide, chloride, fluoride, silica, and sulfate), residue on evaporation (dissolved solids), trace elements (arsenic, barium, boron, chromium, iron, lithium, manganese, molybdenum, selenium, strontium, and vanadium), and selected radionuclides (gross alpha- and beta-particle activity [at 72 hours and 30 days], carbon-14, radium-226, radon-222, and uranium). Field measurements were made of selected physicochemical (relating to both physical and chemical) properties (oxidation-reduction potential, turbidity, dissolved-oxygen concentration, $\mathrm{pH}$, specific conductance, water temperature, and alkalinity) and unfiltered sulfides.

Similar to the results from the reconnaissance survey, physicochemical properties, major ions, and trace elements varied considerably. The ranges of selected physicochemical properties were as follows: oxidation-reduction potential ranged from -173 to 466 millivolts, dissolved oxygen ranged from less than 0.1 to 4.4 milligrams per liter, $\mathrm{pH}$ ranged from 7.2 to 7.8 , specific conductance ranged from 439 to 724 microsiemens per centimeter at 25 degrees Celsius, and alkalinity ranged from 159 to 276 milligrams per liter as calcium carbonate. The largest ranges in concentration for filtered major ion constituents were obtained for cations sodium and calcium and for anions chloride and sulfate. Arsenic concentrations measured in samples from the 47 wells ranged from 1.6 to 23.5 micrograms per liter. The maximum concentration of arsenic (23.5 micrograms per liter) was measured in the source-water sample from well LJ-65-12-328.

Quantifiable concentrations of barium, boron, lithium, molybdenum, and strontium were measured in all 47 filtered, source-water samples. Quantifiable concentrations of manganese were measured in 46 source-water samples, and an estimated concentration of manganese was measured in 1 sample. Chromium, iron, selenium, and vanadium were detected in 24 or more of the 47 source-water samples.

Gross alpha-particle activities and beta-particle activities for all 47 samples were analyzed at 72 hours after sample collection and again at 30 days after sample collection, allowing for the measurement of the activity of short-lived isotopes. Gross alpha-particle activities reported in this report were not adjusted for activity contributions by radon or uranium and, therefore, are conservatively high estimates if compared to the U.S. Environmental Protection Agency National Primary Drinking Water Regulation for adjusted gross alpha-particle activity. The gross alpha-particle activities at 30 days in the samples ranged from R0.60 to 25.5 picocuries per liter and at 72 hours ranged from 2.58 to 39.7 picocuries per liter, and the " $R$ " preceding the value of 0.60 picocuries per liter refers to a nondetected result less than the sample-specific critical level. Gross beta-particle activities measured at 30 days ranged from 1.17 to 14.4 picocuries per liter and at 72 hours ranged from 1.97 to 4.4 picocuries per liter. Filtered uranium was detected 
in quantifiable amounts in all of the 47 wells sampled. The uranium concentrations ranged from 0.03 to 42.7 micrograms per liter. One sample was analyzed for carbon-14, and the amount of modern atmospheric carbon was reported as 0.2 percent. Six source-water samples collected from municipal supply wells were analyzed for radium-226, and all of the concentrations were considered detectable concentrations (greater than their associated sample-specific critical level). Three source-water samples collected were analyzed for radon-222, and all of the concentrations were substantially greater than the associated sample-specific critical level.

\section{Introduction}

Groundwater is used as the source water (the raw, ambient water collected at a supply well prior to water treatment) for much of the municipal water supply needs of the Houston, Tex., area, and the primary sources of groundwater for the Houston area are the Evangeline and Chicot aquifers of the Gulf Coast aquifer system (fig. 1). During March-December 2010, the U.S. Geological Survey (USGS), in cooperation with the city of Houston, collected water-quality data from wells completed in the Gulf Coast aquifer system in the Houston area. These data were collected as part of an ongoing study to determine concentrations, spatial extent, and associated geochemical conditions that might be conducive for mobility and transport of selected naturally occurring contaminants (selected trace elements and radionuclides) in the Gulf Coast aquifer system in the Houston area. In the summers of 2007 and 2008, a reconnaissance-level survey of most of the same constituents measured in 2010 was completed; the samples collected during 2007-08 were untreated water from 28 municipal supply wells in the Houston area. The results from this initial survey and the methods by which the source-water samples were collected and analyzed for each constituent or constituent group were summarized in Oden and others (2010). For the second phase of the study, source-water samples were collected from 60 municipal supply wells in the Houston area between March-December of 2010. Included in this report are the complete analytical results for 47 of the 60 samples (fig. 1) collected in 2010-those results which were received from the laboratories and reviewed by the authors as of December 31, 2010. Selected physicochemical (relating to both physical and chemical) properties and unfiltered sulfides were measured in the field at the time each sample was collected. Source-water samples were analyzed for major ions, selected chemically related properties, trace elements, and radionuclides. The purpose of this ongoing study is to characterize source-water-quality conditions in untreated groundwater prior to drinking-water treatment. An evaluation of contaminant occurrence in source water provides background information regarding the presence of a contaminant in the environment. Because source-water samples were collected prior to any treatment or blending that potentially could alter contaminant concentrations, the sampled groundwater represents the quality of the source water, not the quality of finished drinking water (water that has passed through all the treatment processes and is ready to be delivered to consumers through a community water system (a public water system with 15 or more connections and serving 25 or more year-round residents and thus subject to U.S. Environmental Agency (USEPA) and State regulations enforcing the Safe Drinking Water Act)) (Hopple and others, 2009; U.S. Environmental Protection Agency, 2004).

Many contaminants in groundwater are naturally occurring in aquifers. In a national survey of more than 6,000 domestic wells used for drinking-water supply, naturally occurring contaminants were many times more prevalent in concentrations of concern than were synthetic organic compounds released to the environment by human activity and considered to pose health risks upon ingestion (DeSimone, 2009). The local geology and geochemistry of an aquifer control the occurrence and distribution of naturally occurring contaminants in groundwater, such as arsenic, other trace elements, and radionuclides (Hem, 1992; Welch and others, 2000; Zapecza and Szabo, 1988). During 1993-2007, the USGS sampled untreated source water from 932 public-supply wells as part of multiple groundwater assessments conducted across the United States and found that naturally occurring contaminants (trace elements and radionuclides) might be present in groundwater at concentrations of potential humanhealth concern even in undeveloped areas or confined aquifers where contamination usually is not expected (Toccalino and others, 2010). Toccalino and others (2010) also found that trace elements and radionuclides were detected at concentrations greater than benchmarks in samples from confined and unconfined aquifers, which is consistent with the fact that these contaminants originate primarily from aquifer materials.

Because radionuclides are naturally occurring trace elements found in rocks, soils, and waters, varying degrees of exposure to naturally occurring radioactivity occurs universally. Most naturally occurring radionuclides are formed through the decay of uranium-238 and thorium-232 (fig. 2). Uranium and thorium decay produces other radioactive, daughter elements, which in turn undergo still further radioactive decay. These radioactive, daughter elements exhibit different chemical properties, have shorter half-lives, and emit various types of radiation at different rates and energies than the parent isotope. However, the parent isotope may govern the occurrence and distribution of the daughter isotopes (Zapecza and Szabo, 1988). Radioactive decay is the emission of particles and energy from the nucleus of an atom (a radionuclide) with an unstable configuration within the nucleus. The emitted particles are alpha particles (a nucleus of a helium-4 atom) or beta particles (an electron). Energy also is emitted in the form of gamma rays. The half-life of a radionuclide is defined as the time required for one-half of the original amount of the radionuclide to decay (Zapecza and Szabo, 1988). The half-lives may range from long (years) to short (seconds, hours, or a few days) intervals. For example, radium-226 is a derivative of 


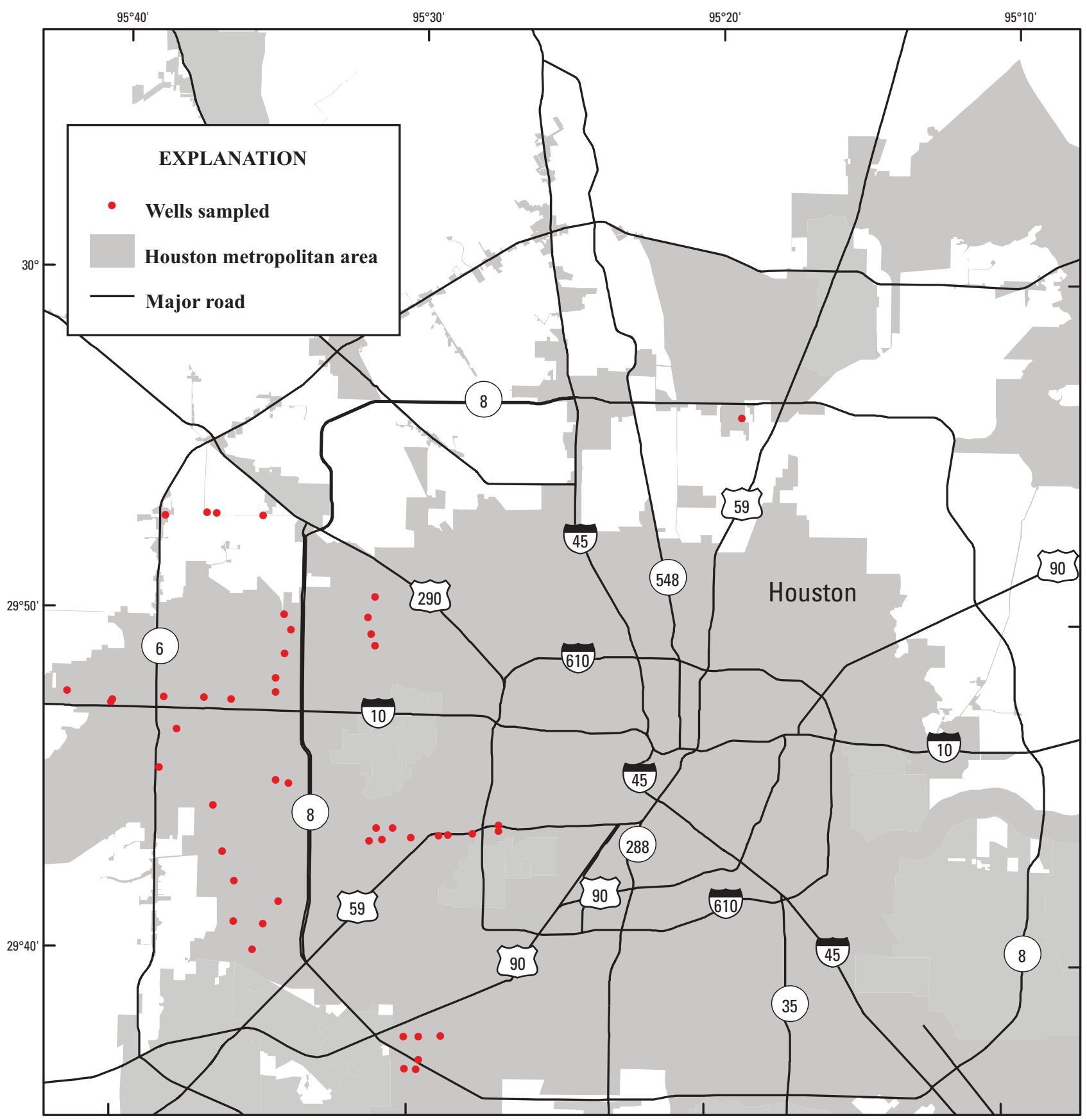

Base from National Atlas of the United States, Digital data, 1:2,000,000 Universal Transverse Mercator projection, Zone 15

North American Datum of 1983
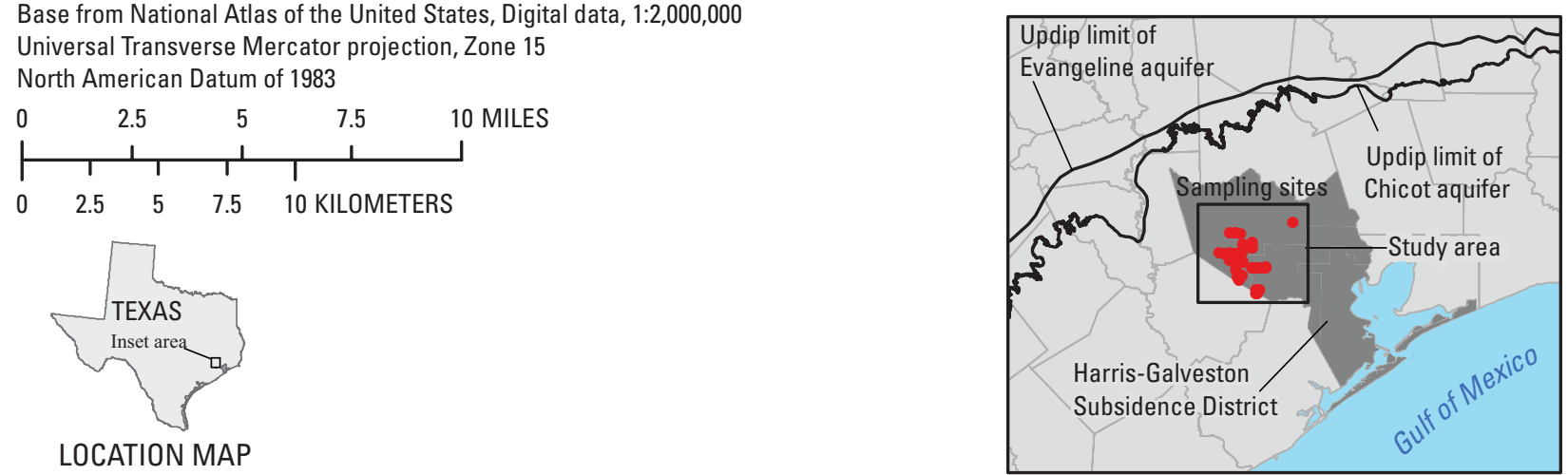

Figure 1. Location of 47 municipal supply wells in the Houston, Texas, area sampled during 2010. 
Uranium-238

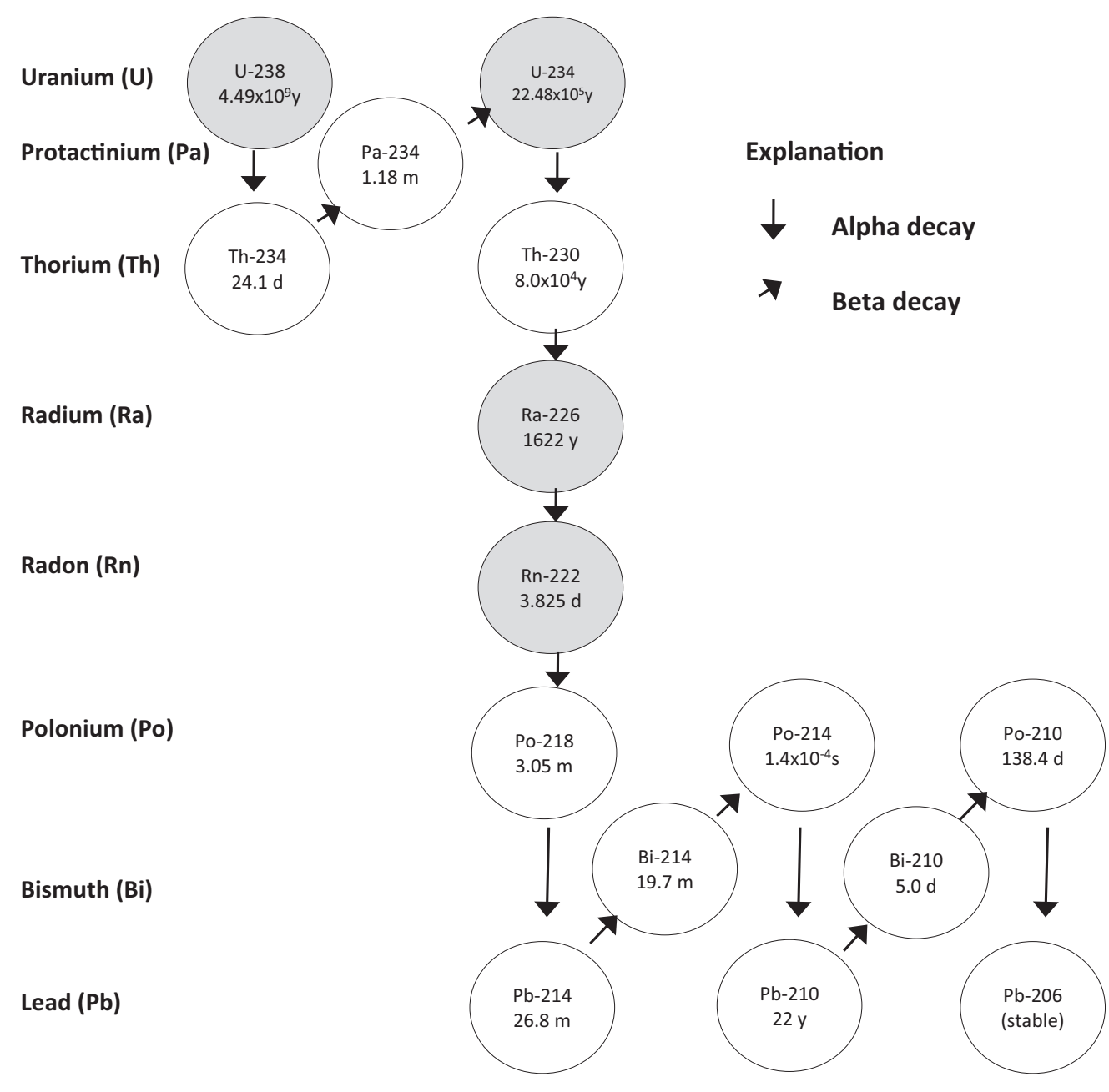

Thorium-232

Thorium (Th)

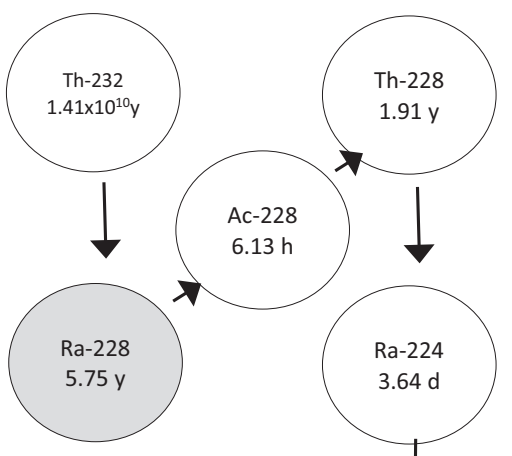

Radon (Rn)

Polonium (Po)

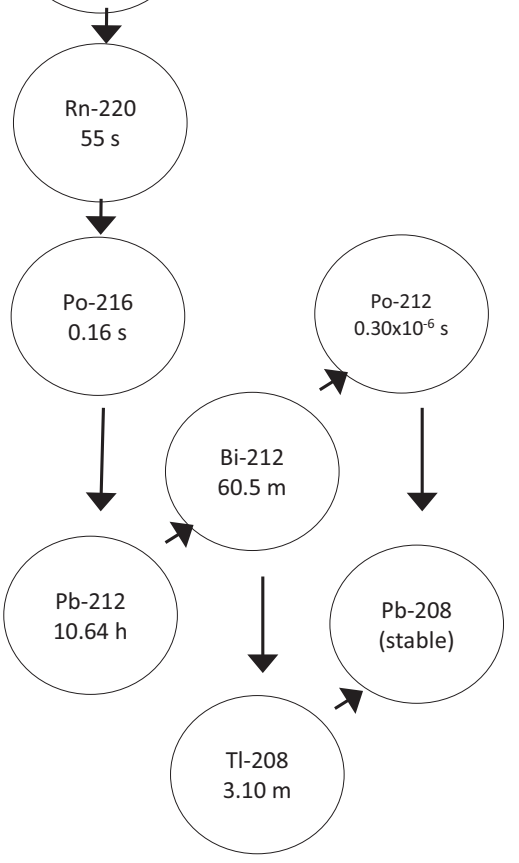

Figure 2. Diagram showing uranium-238 and thorium-232 radioactive decay series. Shading indicates those radionuclides mentioned in report. (Modified from Hall and others, 1985.) [Times shown are half-lives: $y$, years; d, days; h, hours; $m$, minutes; $s$, seconds] 
the uranium-238 decay chain and decays by emitting an alpha particle, whereas radium-228 is derived from thorium-232 and emits a beta particle. Radium-228 has a half life of 5.75 years, and the half life of radium-226 is 1,622 years. Radium-226 decays to radon-222, which has a half-life of 3.8 days (fig. 2). The most common radionuclides in groundwater are radium-226, radium-228, radon-222, uranium-238, and uranium-234 (Zapecza and Szabo, 1988). When a gross activity measurement is made, it represents the overall alpha-particle and beta-particle activity of all the radionuclides present in the sample in the given period of time associated with the measurement (U.S. Environmental Protection Agency, 1997). Gross alpha-particle activities and beta-particle activities for this study were analyzed at 72 hours after sample collection and again at 30 days after sample collection, allowing for the measurement of the activity of short-lived isotopes. Szabo and others (1998) found that gross alpha-particle activity measurements differed when gross activities were measured within 72 hours compared to when analyzed with no adherence to strict holding times, and these differences may be attributed to differing concentrations of long-lived and short-lived isotopes present in the water samples measured.

Proposed and implemented changes to drinking-water regulations have increased the number of community water systems that will need to be monitored and receive mitigation for certain naturally occurring contaminants, arsenic and radionuclides (U.S. Environmental Protection Agency, 2000, 2001). The quality of finished drinking water (after treatment and before distribution) from the Nation's public water systems is regulated by the USEPA under the Safe Drinking Water Act (SDWA) (U.S. Environmental Protection Agency, 2004). Water managers' knowledge about the occurrence and distribution of arsenic and radionuclides in source water has become essential for treatment purposes. For example, recent changes to the USEPA public drinking-water regulations for arsenic and a selected number of natural radionuclides have highlighted the necessity for municipal watersupply managers to be concerned about the occurrence and distribution of these constituents in their respective drinkingwater resources, primarily pertaining to groundwater. The National Research Council (1999) recommended that the USEPA lower the maximum contaminant level (MCL) for arsenic because of ongoing health research that associated the occurrence of arsenic in water to the increased risk of skin and internal cancers in humans. In 2002, the USEPA lowered the MCL for arsenic in finished drinking water from 50 to 10 micrograms per liter $(\mu \mathrm{g} / \mathrm{L})$ and required municipal supply systems to comply with the new standard by January 23, 2006 (U.S. Environmental Protection Agency, 2001) (table 1).

In December 2000, the USEPA updated the regulations pertaining to radionuclides (except radon-222) in finished drinking water (U.S. Environmental Protection Agency, 2000). The revised radionuclide MCLs are listed in table 1 . The new monitoring requirements for the radionuclide contaminants defined in 2000 were phased in between December 2003 and December 31, 2007, the date for all water systems to complete
Table 1. U.S. Environmental Protection Agency maximum contaminant levels for arsenic and radionuclides in finished drinking water, February 2011.

[ $\mu \mathrm{g} / \mathrm{L}$, micrograms per liter; $\mathrm{pCi} / \mathrm{L}$, picocuries per liter; mrem/yr, millirems per year]

\begin{tabular}{ll}
\hline \multicolumn{1}{c}{ Constituent } & Maximum contaminant level ${ }^{1}$ \\
\hline Arsenic & $10 \mu \mathrm{g} / \mathrm{L}$ \\
Gross alpha-particle activity & $15 \mathrm{pCi} / \mathrm{L}^{2}$ \\
Beta/photon emitters & $4 \mathrm{mrem} / \mathrm{yr}(50 \mathrm{pCi} / \mathrm{L} \text { screen })^{3}$ \\
$\begin{array}{l}\text { Radium-226 plus radium-228 } \\
\quad \text { combined radium) }\end{array}$ & $5 \mathrm{pCi} / \mathrm{L}$ \\
Uranium & $30 \mu \mathrm{g} / \mathrm{L}$ \\
Radon-222 (proposed) & $300 \mathrm{or} 4,000 \mathrm{pCi} / \mathrm{L}$ \\
\hline
\end{tabular}

${ }^{1}$ Drinking Water Contaminants, National Primary Drinking Water Regulations (U.S. Environmental Protection Agency, 2011).

${ }^{2}$ Excluding uranium and radon.

${ }^{3}$ Dose (millirems per year) determined on basis of individual isotope analyses.

initial monitoring (U.S. Environmental Protection Agency, 2000). The USEPA MCL for adjusted gross alpha-particle activity is 15 picocuries per liter ( $\mathrm{pCi} / \mathrm{L}$ ) minus activity caused by uranium and radon, if applicable (U.S. Environmental Protection Agency, 2000). The regulation defines the maximum holding time as 6 months for samples that are analyzed for gross alpha-particle activity, with annual compositing of samples (combining samples collected from the same sampling point from different quarters) allowed. Compositing of samples is done in the laboratory at the time of analysis (U.S. Environmental Protection Agency, 2000). For betaparticle activity, the USEPA states that the water systems must increase monitoring frequency if the gross beta-particle activity minus the naturally occurring potassium-40 activity is equal to or greater than $50 \mathrm{pCi} / \mathrm{L}$, and individual isotopes may be targeted for analysis (U.S. Environmental Protection Agency, 2000). The radium MCL is defined as $5 \mathrm{pCi} / \mathrm{L}$ for the sum of the radium isotopes, radium-226 and radium-228 (the sum of which is referred to as combined $\mathrm{Ra}$ ). The revised monitoring requirements included monitoring for radium-228 as well as radium-226, and required water-system managers to monitor for these radioactive constituents at each entry point into a distribution system. Also, the sampling frequency requirements for radionuclides were changed to be more consistent with those required for other National Primary Drinking Water Regulations. This "radioactivity rule" also established a new MCL of $30 \mu \mathrm{g} / \mathrm{L}$ for uranium, which previously had been unregulated (U.S. Environmental Protection Agency, 2000).

USEPA proposed separate regulation for radon-222 in finished drinking water in 1999, with an MCL of $300 \mathrm{pCi} / \mathrm{L}$ 
and an alternative MCL (AMCL) of 4,000 pCi/L (U.S. Environmental Protection Agency, 1999) that has yet (2011) to be adopted (table 1). Whether the MCL or AMCL applies to a community water system depends on whether or not the State in which it resides or the community water system itself develops a multimedia mitigation program (MMM) to address health risks from radon in indoor air. The lower proposed MCL for radon would apply to those that do not develop MMM programs; conversely, the proposed AMCL would only apply to those that do (U.S. Environmental Protection Agency, 1999).

Elevated concentrations of arsenic and natural radionuclides in drinking-water sources from groundwater have been documented in several regions of the United States (Focazio and others, 2000; Welch and others, 2000; Focazio and others, 2001; Ryker, 2003; DeSimone, 2009). Targeted reconnaissance sampling by Focazio and others (2001) showed that Texas is one of more than a dozen States with relatively large concentrations of radium in raw-water (untreated) samples from municipal water supplies obtained from aquifers. Chowdhury and others (2006) analyzed the radionuclide data available in the Texas Water Development Board groundwater database for the Gulf Coast aquifer system, which were primarily gross alpha- and beta-particle activity results, with a few radium-226 and radon-222 analyses. The highest gross alpha-particle activities ( 61 to $210 \mathrm{pCi} / \mathrm{L}$ ) were measured from wells screened in the Evangeline aquifer, part of the Gulf Coast aquifer system, in Harris County, Tex., and other counties south of Bee County, Tex. (Chowdhury and others, 2006; figs. 5-24). Chowdhury and others (2006) also summarized the arsenic data collected from wells screened in the Gulf Coast aquifer system in Texas and reported that arsenic concentrations ranged from 2 to $569 \mu \mathrm{g} / \mathrm{L}$ for samples obtained from the three aquifers (Chicot, Evangeline, and Jasper) that compose the Gulf Coast aquifer system.

\section{Purpose and Scope}

This report presents the results for physicochemical (relating to physical and chemical) properties and waterquality constituents (major ions, selected trace elements, and selected radionuclides) measured in water-quality samples from 47 of the 60 municipal supply wells sampled in the Houston area in between March and December 2010. The ranges of concentrations for the water-quality constituents are described, and the results for arsenic and radionuclides are compared to MCLs defined in the National Primary Drinking Water Regulations established by the USEPA as a reference to provide an initial perspective on the potential significance of contaminants detected in the source water. The methods by which the samples were collected and analyzed are described for each constituent or constituent group, and quality-control results also are summarized. This report documents sourcewater quality prior to drinking-water treatment, which might differ from the quality of finished drinking water distributed through community water systems. In this study of untreated source waters, contaminant concentrations that are greater than MCLs do not represent MCL violations because MCLs apply to finished drinking water, and all samples were collected from source waters. None of the source-water samples were collected for regulatory compliance purposes; further, compliance with most MCLs is based on running annual average concentrations determined from the results of multiple samples at each entry point to the distribution system (U.S. Environmental Protection Agency, 2000; U.S. Environmental Protection Agency, 2001), not on concentrations detected in single samples as collected in this study.

\section{Description of Study Area}

Houston, Tex., is the fourth largest city in the United States and growing rapidly; the population for the Houston metropolitan area as of January 1, 2010, was about 5.9 million, a 25.5 percent increase since the 2000 census (Texas State Data Center, 2010). Historically, the water supply for the city of Houston has been groundwater, and the groundwater withdrawals have increased over time, primarily for municipal use. Steadily increasing groundwater withdrawals in most parts of the greater Houston area for much of the city's history resulted in declining groundwater levels, which in turn has caused land subsidence (Ryder and Ardis, 2002; Kasmarek and others, 2010). The Texas Legislature created the HarrisGalveston Subsidence District in 1975 to regulate groundwater withdrawal in the Houston area because land subsidence was increasing the risk of flooding and fault activity; an increased use of surface water to prevent future subsidence also was mandated (Ryder and Ardis, 2002). Under the 1999 regulatory plan issued by the Harris-Galveston Subsidence District, a goal was established for the northern and western parts of Harris County to reduce groundwater usage 30 percent by 2010; the goal by 2030 is for groundwater to account for less than 20 percent of total water usage in Harris and Galveston Counties (Michel, 2006). Even though the plan is to reduce the amount of groundwater used in the Houston area, the population of the area is expected to continue to grow rapidly. Maintaining the drinking-water quantity and quality of the municipal water supply is a priority for the water-resource managers in the area regardless of the source.

The greater Houston area overlies and obtains groundwater from the Gulf Coast aquifer system. The Gulf Coast aquifer system consists mostly of unconsolidated sediments of Miocene age and younger that lie above and coastward of the Paleocene Catahoula Sandstone. The Gulf Coast aquifer system reflects three depositional environments: continental (alluvial plain), transitional (delta, lagoon, and beach), and marine (continental shelf). Coarser grained nonmarine deposits updip and grade laterally into finer grained material that was deposited in marine environments (Ryder, 1996). The system consists of a fluvial-deltaic wedge of discontinuous beds of sand, silt, and clay sediments deposited in bands that parallel the Gulf of Mexico and range in age from Miocene to Holocene. This wedge of unconsolidated to poorly 
consolidated sediments increases in thickness and depth toward the Gulf of Mexico (Ryder, 1996). Aquifers typically consist of interbedded sand and clay rather than the massive, areally extensive sand beds or sheet sands common in places such as the Atlantic Coastal Plain aquifers and aquifer systems, which were deposited as beach sands or shallow-shelf sandbars in cyclic progressive/regressive sequences (Hansen, 1971; Sugarman and Miller, 1997). Lenticular sand and clay beds of the aquifer system have lateral and vertical boundaries that are gradational, poorly constrained, and difficult to trace more than a few miles (Renken, 1998). The Chicot aquifer, Evangeline aquifer, Burkeville confining unit, and Jasper aquifer comprise the Gulf Coast aquifer system (fig. 3). The Chicot and underlying Evangeline aquifers are hydraulically connected and not separated by a distinct confining unit; the aquifers are identified on the basis of a gradational decrease in grain size with depth. The Chicot and Evangeline aquifers are the primary sources of groundwater used for drinking water for the City of Houston.

\section{Well Information}

The USGS collected source-water samples from 47 municipal supply wells during 2010 (table 2, at end of report). Of these 47 wells, 22 were screened entirely in the Evangeline aquifer. The remaining 25 wells contained screened intervals that intersected both Evangeline and Chicot aquifers. The depths of the 47 wells ranged from 734 to 1,965 feet below land surface (ft bls). The depth to the top of the first screen interval for each well ranged from 372 to 1,146 ft bls, and the depth to the bottom of the last screen interval ranged from 710 to $1,946 \mathrm{ft}$ bls (table 2). When available, the lithologic code summarizes the sand and clay composition of the aquifer material for the total depth of the well as reported in associated drillers' logs. A lithologic code of CLSD describes aquifer material with a greater percentage of clay than sand as compared to a code of SDCL or SNCL, which describes aquifer material with a greater percentage of sand than clay.

\section{Methods}

\section{Sample Collection}

Samples were collected and processed in accordance with protocols established by the USGS "National Field Manual for the Collection of Water-Quality Data" (U.S. Geological Survey, variously dated). These sampling protocols ensure that a representative sample of groundwater is collected at each site, and samples are collected and processed in a way that minimizes sample contamination. Groundwater samples were collected as near to the wellhead as possible, prior to treatment. Prior to sampling, each well had been pumping for a minimum of 30 minutes. Field measurements of selected physicochemical properties (oxidation reduction potential, turbidity, dissolved-oxygen concentration, $\mathrm{pH}$, specific conductance, and water temperature) were made; each physicochemical property was monitored for stabilization prior to sampling to ensure that the water sampled from the well was representative of water from the aquifer (U.S. Geological Survey, variously dated). Water samples were collected using Teflon tubing, C-Flex tubing, and stainless steel fittings attached to a spigot close to the wellhead and prior to any treatment. Tubing from the spigot was extended into a mobile water-quality laboratory used for sample collection and processing. The tubing inside the mobile laboratory was connected to a Teflon manifold to split water to the sample-collection chamber and to the multiparameter instrument used for measuring field parameters. Water pumped from the well was passed through the manifold and through a flow-through chamber that contained a water-quality monitor, a YSI 600XL multiprobe waterquality sonde. The multiprobe sonde simultaneously measures oxidation-reduction potential, dissolved-oxygen concentration, $\mathrm{pH}$, specific conductance, and water temperature; measurements were recorded every 5 minutes.

Turbidity was measured separately in grab samples collected every 5 minutes using a Hach 2100P benchtop turbidimeter. All sensors on the multiparameter instrument and turbidimeter were calibrated daily. Field measurements were recorded at 5-minute intervals until five sequential readings of field measurements were within the stabilization criteria (Wilde, 2008). In cases where the dissolved-oxygen concentration was less than 2.0 milligrams per liter $(\mathrm{mg} / \mathrm{L})$, the final dissolved-oxygen concentration was determined by a spectrophotometric method using the Rhodazine-D colorimetric method to minimize atmospheric interaction with the water sample (Lewis, 2006). When the dissolved oxygen was measured as less than $1.0 \mathrm{mg} / \mathrm{L}$ or the oxidation-reduction potential was less than 200 millivolts $(\mathrm{mV})$, unfiltered sulfides also were measured in the field by following the Methylene Blue Method (American Public Health Association, American Water Works Association, and Water Pollution Control Federation, 2005, Section 4500; CHEMetrics, 2008). A V-2000 photometer with CHEMetrics field supplies and method was used to measure unfiltered sulfides (CHEMetrics, 2008). Lastly, alkalinity was determined by the incremental titration method (Rounds, 2006).

All water-quality samples, with the exception of those analyzed for radon-222, were collected and processed inside a field-portable collection chamber inside the dedicated mobile water-quality laboratory. A chamber consists of a frame and a new plastic-bag covering used at each site and discarded after one-time use (U.S. Geological Survey, variously dated). All samples, except those for radon analyses, were filtered during collection. Filtered samples were processed using a 0.45-micrometer polysulfone ether capsule filter. The capsule filter was preconditioned the day of use with 1 liter of American Society for Testing and Materials (ASTM) standard Type I deionized water (ASTM International, 2006a) and stored chilled at 4 degrees Celsius $\left({ }^{\circ} \mathrm{C}\right)$ until use. Polyethylene 
A NORTHWEST

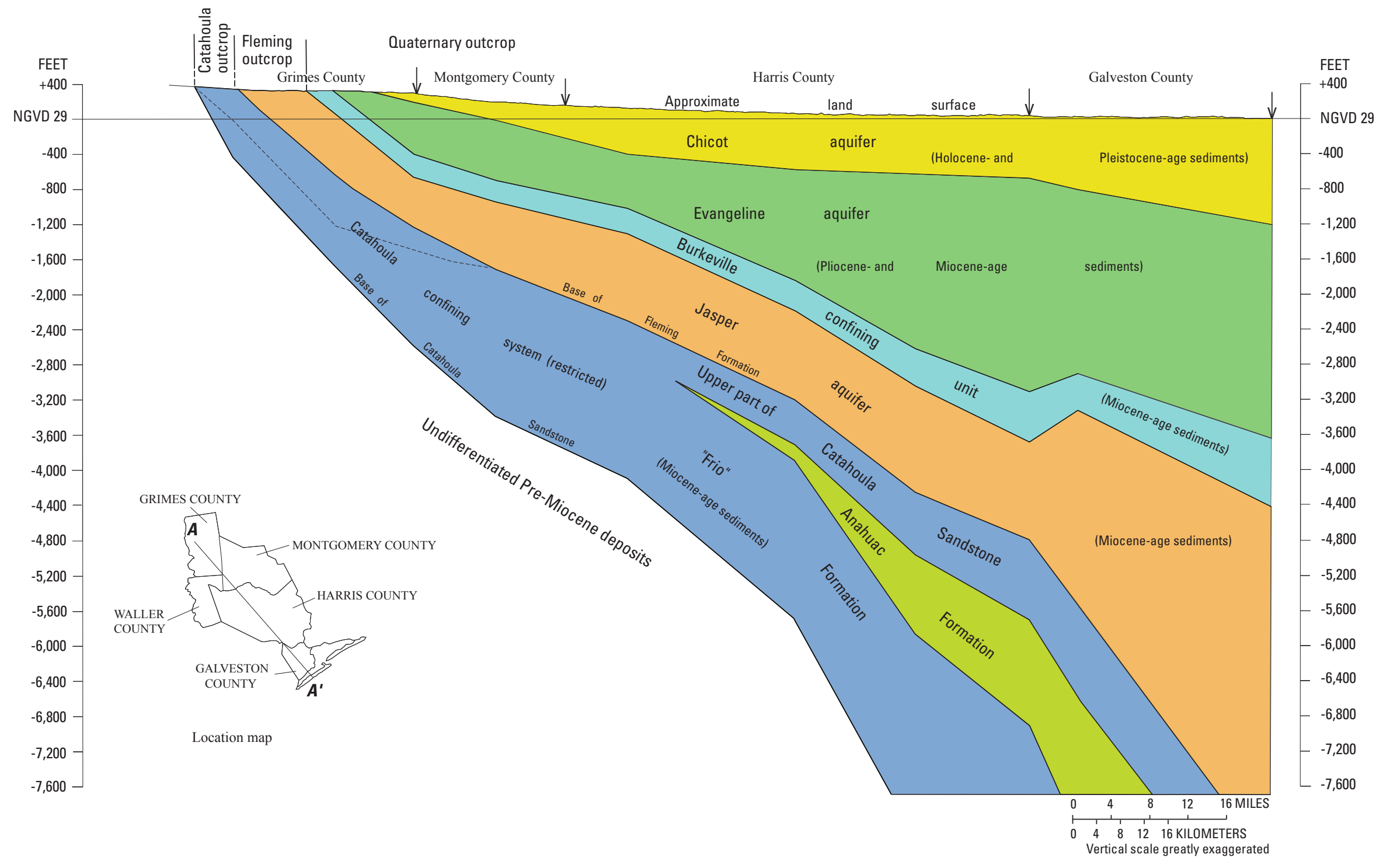

Figure 3. Hydrogeologic section of the Gulf Coast aquifer system in Harris County and adjacent counties, Texas (modified from Baker, 1979, fig. 4). 
bottles were preconditioned; each bottle was rinsed three times and transported to the field approximately one-half full of Type I deionized water. Upon attaching the capsule filter to the sample collection line, the air was worked out of the filter, and 100 milliliters $(\mathrm{mL})$ of native water were passed through the filter before collection. The preconditioned polyethylene bottles were emptied and given a one-time $25-\mathrm{mL}$ filtered native water rinse, then filled to the shoulder of the bottle. All samples were preserved after collection, except those for major anions and carbon-14 analyses. When used, preservatives such as nitric acid were added to the samples in a preservation chamber. Ultrapure nitric acid was added to each bottle for cation or trace- element analysis, lowering the $\mathrm{pH}$ to 2 or less. All samples were shipped overnight to the analyzing laboratory. Most samples were stored at ambient temperatures until analyzed; those for temperature-sensitive constituents that could change as a result of biological activity were maintained at $4{ }^{\circ} \mathrm{C}$ until they were analyzed (U.S. Geological Survey, variously dated).

Radon-222 samples were collected outside the chamber using a brass sampling valve with a Teflon septum. The 10-mL sample was collected using a rinsed, glass syringe with a stainless steel needle. The needle was inserted through the septum, and the valve partially closed to fill the syringe under pressure. The 10-mL sample then was injected into a USGSprepared borosilicate glass scintillation vial prefilled with 10-mL scintillation oil. The vial was sealed with a polycone cap and shaken for 30 seconds to extract the radon into the oil, then placed in a protective cardboard tube, and shipped to the USGS National Water Quality Laboratory (NWQL) in Denver, Colo.

\section{Sample Analysis}

Three laboratories analyzed samples for this study. The USGS NWQL in Denver, Colo., was the primary laboratory; two other laboratories were contracted by the NWQL for certain analyses. The NWQL maintains National Environmental Laboratory Accreditation Conference (NELAC) and other certifications (U.S. Geological Survey, 2010a). Samples were analyzed at the NWQL for major ions (calcium, magnesium, potassium, sodium, bromide, chloride, fluoride, silica, and sulfate), residue on evaporation (dissolved solids), trace elements (arsenic, barium, boron, chromium, iron, lithium, manganese, molybdenum, selenium, strontium, and vanadium), radon-222, and uranium. Gross alpha- and beta-particle activities (at 72 hours and 30 days) and radium-226 were analyzed by Eberline Services in Richmond, Calif. One carbon isotope sample was collected and sent to the National Ocean Sciences Accelerator Mass Spectrometry (NOSAMS) Facility in Woods Hole,

Mass., for the carbon-13 to carbon-12 isotopic ratio and carbon-14 analysis. Anion concentrations were measured by ionexchange chromatography, and major cation concentrations (along with iron concentrations) were measured by inductively coupled plasma-atomic emission spectrometry (ICP-AES) as described by Fishman (1993). Concentrations of filtered arsenic, chromium, selenium, and vanadium were measured using collision-reaction cell inductively coupled plasma-mass spectrometry (cICP-MS) as described by Garbarino and others (2006). The remaining six trace elements (filtered barium, boron, lithium, manganese, molybdenum, and strontium) were measured using inductively coupled plasma-mass spectrometry (ICP-MS) (Faires, 1993; Garbarino, 1999).

Gross alpha- and beta-particle activities were measured by a gas flow proportional planchet counting the residue on evaporation by using USEPA Method 900.0 (U.S. Environmental Protection Agency, 2008). Gross alpha- and beta-particle activities were measured at 72 hours after collection and again 30 days after collection, allowing the activity of short-lived isotopes to be measured (Parsa, 1998; Szabo and others, 2005). Gross alpha- and beta- particle activities are referred to as filtered, alpha or beta radioactivity, 72-hour or 30-day count, in the tables in this report. Isotopic ratio of carbon-13 to carbon-12 was determined by mass spectroscopy, and accelerator mass spectroscopy was used to determine the amount of carbon-14. Radium-226 concentration was measured by radon de-emanation by using USEPA Method 903.1 (U.S. Environmental Protection Agency, 2008). Radon-222 concentration was measured by liquid-scintillation counting (ASTM International, 2006b). Filtered, natural uranium was measured by ICP-MS (Faires, 1993; Garbarino, 1999).

\section{Reporting of Results}

The analytical quantification procedure used by the NWQL for reporting results is based on the long-term method detection level (LT-MDL) and laboratory reporting level (LRL). The LT-MDL concentrations are defined as a censoring limit for most analytical methods at the NWQL, and its purpose is to limit the false positive rate to less than or equal to 1 percent. An LT-MDL is a modification of the USEPA 40 Code of Federal Regulations Part 136 definition of the method detection limit (MDL). The LRL is defined as twice the LT-MDL and is established to limit the occurrence of false negative detections to less than or equal to 1 percent (Childress and others, 1999). A constituent concentration is considered estimated by the laboratory when results are greater than the LT-MDL and less than the LRL; that is, a detection is considered likely, but quantification is considered questionable. The remark code of " $E$ " (estimated) is assigned by the laboratory for these results. The presence of a constituent in the sample that can be verified, but the concentration is not enough to be quantified, is reported as a remark code of "M." Similarly, nonzero concentration values that round to zero are converted to a null value on output and reported by using a remark code of "M" (U.S. Geological Survey, 2009). Beginning in October 2010, the NWQL changed the reporting convention for all inorganic analytes that use the LRL convention. For these constituents, the reporting level was set at the LT-MDL concentration. Concentrations that are less than the LT-MDL are reported as "less than" the LT-MDL concentration (<LT-MDL) and a remark code of "E" (estimated) would 
no longer be assigned to results greater than the LT-MDL and less than the LRL (U.S. Geological Survey, 2010b). For this report, inorganic analyses are reported using this new convention for samples collected after October 1, 2010.

Radionuclide results are reported in picocuries per liter, which equals 2.22 radioactive disintegrations per minute per liter of water. As defined in Focazio and others (2001, p. v), picocuries per liter is a unit expressing the concentration (activity) of radionuclides in solution as particles emitted per unit volume (liter) of water. By definition, 1 gram of radium has 1 curie of activity. A picocurie is a millionth of a millionth of a curie. The measured activity of any single isotope is considered a concentration because a mass is linked directly to activity by the radioactive decay equation and half life.

The gross activity measurements are considered activities and not concentrations because there is no identifiable half life or isotope mass associated with the measurement. The laboratory reports the unrounded values for all the radionuclide concentrations along with a 1-sigma combined standard uncertainty (CSU) and a sample-specific critical level $\left(\mathrm{ssL}_{\mathrm{C}}\right)$ for each result. Some of the raw (unrounded) radionuclide results are reported as negative values, indicating the radiation count of the sample over the fixed interval of time when the measurement made was less than the long-term average background radiation reported routinely by the instrument (Troyer and others, 1991). The 1-sigma CSU is a calculated measure of uncertainty of the laboratory analysis; specifically, the sum of the laboratory and counting uncertainty. By definition, the true radionuclide concentration plus or minus the 1-sigma CSU has a 68-percent probability (based on one standard deviation of the radioactivity count) that it is within range of the reported measured value (McCurdy and others, 2008). For each radionuclide analyzed, the laboratory computes a critical level $\left(\mathrm{L}_{\mathrm{C}}\right)$, which is the minimum quantity of a radionuclide detectable by the counting instrument that is statistically different from the instrument background or analytical blank. It is calculated from typical analytical parameter values. The $\mathrm{ssL}_{\mathrm{C}}$ is sample specific because it is calculated for each measurement of a radionuclide constituent using the same analytical parameter values that were used during the analysis of the sample. If the measured concentration is greater than the $\mathrm{ssL}_{\mathrm{C}}$, it is considered a detected value. If the result is less than its associated $\mathrm{ssL}_{\mathrm{C}}$, a remark code of " $\mathrm{R}$ " is assigned to indicate that it is a nondetection (McCurdy and others, 2008). The $\mathrm{ssL}_{\mathrm{C}}$ is like the LT-MDL for nonradioactive constituents except that the $\mathrm{ssL}_{\mathrm{C}}$ calculations use a 5-percent error rate for false detection compared to a 1-percent error rate for false detections used for LT-MDL calculations.

For each radionuclide measurement, the laboratory calculates a sample-specific minimum detectable concentration (ssMDC), which is a performance measure for the laboratory that is approximately twice the $\mathrm{L}_{\mathrm{C}}$ (Currie, 1968). The ssMDC is computed individually for each radionuclide sample on the basis of the instrument operating conditions at the time of the measurement and variations in background radioactivity over time (Focazio and others, 2001). In cases where the result is less than its associated ssMDC, the result is considered poorly quantified. Unlike the $\mathrm{ssL}_{\mathrm{C}}$, which addresses the false detection type errors associated with the measurement, the ssMDC addresses false nondetection type errors and is computed by the laboratory after the measurement and the $\mathrm{ssL}_{\mathrm{C}}$ criterion are calculated. The ssMDC is used by the laboratory to verify that the a priori minimum detectable concentration (MDC) was achieved during analysis; the a priori MDC is the method detection concentration calculated before the measurement is made, and is defined as the lowest concentration resulting in a 95-percent confidence level (probability) that the measured value is greater than the $\mathrm{L}_{\mathrm{C}}$ (McCurdy and others, 2008).

\section{Quality Control}

Quality-control data were collected to assess the precision and accuracy of sample-collection procedures and laboratory analyses (U.S. Geological Survey, variously dated). Quality-control samples consisted of two equipment blank samples with accompanying topical quality-control samples, two field blank samples, and four sequential replicate samples. Topical quality-control samples address specific qualitycontrol needs (U.S. Geological Survey, variously dated). The topical quality-control samples collected for this study were designed to identify equipment contributing to low-level contamination to the equipment blank results. Each set of topical samples represented a specific component of the sampling system; for example, extension tubing blank before manifold and sample tubing plus manifold blank.

On an annual basis before the beginning of each field sampling effort, equipment blanks were collected in a controlled laboratory environment to help verify that none of the sampling equipment used to pump and filter the groundwater samples was contributing appreciable amounts of the constituents of concern measured in the environmental samples. Field blank samples also were collected in conjunction with environmental samples to ensure equipment cleaning done in the field between sites was adequate, and that the collection, processing, or transporting procedures in the field did not contaminate the samples. Results for the equipment and field blank samples are listed in table 3 (at end of report).

Sequential replicate samples are collected to measure the variation in results originating from sampling and analytical methods. Sequential replicate sample results are included in tables 4, 5, and 6 (at end of report) with the environmental sample results for alkalinity, major ions, trace elements, and radionuclides. Inorganic constituent replicates were collected with a new, preconditioned capsule filter. Capsule filters were replaced prior to collecting the sequential replicate in case of filter loading, which might reduce the effective pore size of the filter (Horowitz and others, 1996).

The equipment blank results indicate the sampling equipment did not introduce appreciable amounts of the constituents of interest to the samples; with a few exceptions, most of the equipment blank results were less than the applicable LRLs. Low level concentrations of calcium and barium were detected 
in some of the equipment blank samples (table 3). Calcium was detected in the equipment blank collected on March 15, 2010, at a concentration of $0.06 \mathrm{mg} / \mathrm{L}$, with a LRL of 0.04 $\mathrm{mg} / \mathrm{L}$. The equipment blank sample collected on August 5, 2010, had an estimated calcium concentration of $0.03 \mathrm{mg} / \mathrm{L}$. The concentrations of calcium measured in the environmental samples ranged from 14.4 to $69.7 \mathrm{mg} / \mathrm{L}$ (table 4 ). On the basis of a detected amount of calcium of $0.06 \mathrm{mg} / \mathrm{L}$ in an equipment blank, calcium concentrations in environmental samples, at most, might change by less than 1 percent as a result of calcium introduced from the sampling equipment. The barium result for the equipment-blank sample collected on March 15,2010 , was reported as "M," indicating that the constituent was detected but not quantifiable (equal to or greater than the LRL). In the sample collected on August 5, 2010, the concentration for barium was reported as less than the LRL.

The field blank results indicate the sample collection and handling procedures did not introduce appreciable contamination of the constituents of interest to the environmental samples, with a few exceptions, and provided another indication that representative samples were collected from the aquifer. The field blank results included a few estimated results for calcium, potassium, barium, and strontium (table 3). An estimated calcium concentration of 0.02 and $0.03 \mathrm{mg} / \mathrm{L}$ were reported in March and April 2010 (LRL 0.04 mg/L), respectively. The potassium result for the field blank collected on March 29, 2010, was E0.06 mg/L, with a LRL of 0.06 $\mathrm{mg} / \mathrm{L}$ (table 3 ). Because the concentrations measured in the field blanks were low, the results were not of concern, particularly for calcium and potassium. The calcium and potassium concentrations in the field blanks were much less than the minimum concentrations measured in the environmental samples of 14.4 and $1.53 \mathrm{mg} / \mathrm{L}$, respectively (table 4). The barium results for the field blank samples collected on March 29 and April 8, 2010, were reported as "M," indicating that the constituent was detected but not quantifiable (table 3 ). The barium LRL was $0.14 \mu \mathrm{g} / \mathrm{L}$. The strontium result for the field blank sample collected on April 8, 2010 was E0.20 $\mu \mathrm{g} / \mathrm{L}$, with a LRL of $0.40 \mu \mathrm{g} / \mathrm{L}$. The strontium estimated concentration in the field blank was much less than the minimum concentration measured in the environmental samples of $316 \mu \mathrm{g} / \mathrm{L}$ (table 5).

The blank results collected during 2010 did show some low-level, manganese contamination in the environmental sample concentrations. In all of the equipment and field blanks, there were detectable concentrations of manganese measured (table 3). The concentration of manganese in the equipment blank collected on March 15, 2010, was $2.4 \mu \mathrm{g} / \mathrm{L}$, which was more than the concentration of manganese measured in 9 of the 40 environmental samples collected between March and May 2010. The concentration of manganese in the equipment blank collected in August 5, 2010, was $1.3 \mu \mathrm{g} / \mathrm{L}$, which was greater than or equal to two of the seven samples collected between October and November 2010 and included in this report. The concentrations of manganese measured in the 47 environmental samples included in this report ranged from an estimated concentration of 0.2 to $56.3 \mu \mathrm{g} / \mathrm{L}$ (table 5).
Not included in this report are the results for the field blank collected in November 2010, or the results for the topical quality-control samples that were collected during the processing of the equipment blank collected on August 25,2010 . The results for these additional samples were not received in time to be included in this report. Currently (March 2011), the cause of the low-level contamination of manganese in the equipment and field blank data available as of December 31,2010 , is unknown. It is also unknown if the contamination occurred in the blank sample collected in November 2010 for which the data were not received in time to be included in this report. It is unlikely the blank water used to prepare the blank samples was the source of contamination; the certificates of analysis for the certified inorganic blank water and the filters used to process these blank samples did not report detectable amounts of manganese. During the first phase of this project in 2007-08, the manganese concentrations measured in the equipment and field blanks ranged from an estimated concentration of $0.2 \mu \mathrm{g} / \mathrm{L}$ to less than the LRL of $0.2 \mu \mathrm{g} / \mathrm{L}$ (Oden and others, 2010). Also, the instrument blank results at the NWQL for this analysis measured between March 2 and December 30, 2010 , ranged from -0.22 to $3.22 \mu \mathrm{g} / \mathrm{L}$, with a median of 0.01 $\mu \mathrm{g} / \mathrm{L}$, and higher concentrations in blanks appeared to have occurred more frequently between May and October 2010 (Doug Stevenson, U.S. Geological Survey, written commun., 2011). Because the detectable concentrations of manganese occur in the equipment and field blanks, the contamination is likely not introduced during the field processing of samples.

Replicate samples were compared with associated environmental samples to assess the variability of the measured concentrations by computing the relative percent difference (RPD) for each constituent with the following equation:

$$
\mathrm{RPD}=\left|\mathrm{C}_{1}-\mathrm{C}_{2}\right| /\left(\left(\mathrm{C}_{1}+\mathrm{C}_{2}\right) / 2\right) \times 100
$$

where

$\mathrm{C}_{1}$ is constituent concentration, in milligrams per liter, from the environmental sample; and

$\mathrm{C}_{2}$ is constituent concentration, in milligrams per liter, from the replicate sample.

Relative percent differences of 10 percent or less indicate good agreement between the paired results for major ion or trace element analyses if the concentrations are sufficiently large compared to their associated LRL. RPDs for replicates with small concentrations are often large; differences between small concentrations result in large RPDs. In table 7 (at end of report), the minimum, average, and maximum RPDs are listed for selected constituents. An RPD was not computed for a replicated constituent if the paired results were censored as estimated or less than their associated LRL. A replicated constituent was included in table 7 if an RPD could be calculated for two or more pairs of replicate results out of the four sequential replicate samples collected during 2010. Some replicated constituents (unfiltered sulfide, filtered chromium and vanadium) had only one pair of replicated results where a 
detected amount was reported for each member of the pair; the RPDs for these replicate pairs ranged from 0.8 to 46 percent, and these RPD results were not included in the table of minimum, average, and maximum RPDs (table 7). The RPD of 46 percent was for a chromium replicate where the concentrations were not much larger than the LRL. The RPD for unfiltered sulfide was 29 percent, and both concentrations were not much larger than the LRL of $0.20 \mathrm{mg} / \mathrm{L}$. The minimum, average, and maximum RPDs for the remaining constituents are listed in table 7. The RPD for the major ion and trace element constituents ranged from 0 to 17 percent; manganese and selenium, with an RPD of 17 and 15 percent respectively, were the only constituents with an RPD greater than 10 percent. In these instances, the manganese and selenium concentrations were not much larger than their LRLs (table 5).

Each radionuclide concentration or activity is reported as an unrounded value along with its 1-sigma combined standard uncertainty (CSU). The acceptable RPD for radionuclide results was not set to a value but instead determined as acceptable if the unrounded, paired results were within 1 standard deviation (as represented by the 1-sigma CSU for each radionuclide). The RPDs for the radionuclide results ranged from 0 to 32 percent. The concentrations and activities in all but four of the radionuclide result pairs were within 1 standard deviation, indicating the results were within the uncertainty of the analysis. The four replicate pairs that were not within 1-sigma CSU were the gross alpha-particle activity (30-day count) collected on March 23, 2010, the gross alpha-particle activity (72-hour count) collected on March 17, 2010, and the gross beta-particle activity (30-day count) collected on March 17 and April 5, 2010 (table 7).

\section{Groundwater Quality}

Results of the physicochemical properties and major ions are presented in table 4, arsenic and other selected trace elements in table 5, and radionuclides in table 6. Carbon-14, radium-226, and radon-222 were measured in a select number of wells and included in table 6. These data are listed by U.S. Geological Survey site number and State well number and in chronological order by the date and time of sampling. One well, LJ-65-12-328, was sampled twice-first on March 17, 2010, and again on May 6, 2010. The additional environmental sample collected on May 6, 2010, was to confirm results of the first environmental sample. So that each well is represented by one set of results, the additional May 2010 results for well LJ-65-12-328 are included in tables 4-6 but are not included in the description of ranges of concentrations for the constituents.

\section{Physicochemical Properties and Major Ion Chemistry}

Similar to the results from the reconnaissance survey (Oden and others, 2010), physicochemical properties (oxidation-reduction potential, turbidity, dissolved-oxygen concentration, $\mathrm{pH}$, specific conductance, temperature [air, water], alkalinity, and residue on evaporation [dissolved solids]) and major ions (calcium, magnesium, potassium, sodium, bromide, chloride, fluoride, silica, sulfate, and sulfide) varied more for some groundwater samples than for others (table 4). For the environmental samples from the 47 wells sampled during the study, the ranges of selected physicochemical properties were as follows: oxidation-reduction potential ranged from -173 to $466 \mathrm{mV}$, dissolved oxygen ranged from less than 0.1 to $4.4 \mathrm{mg} / \mathrm{L}$, $\mathrm{pH}$ ranged from 7.2 to 7.8 , specific conductance ranged from 439 to 724 microsiemens per centimeter at $25^{\circ} \mathrm{C}$ $(\mu \mathrm{S} / \mathrm{cm})$, and alkalinity ranged from 159 to $276 \mathrm{mg} / \mathrm{L}$ as calcium carbonate $\left(\mathrm{CaCO}_{3}\right)$. After review, the oxidation-reduction potential results measured in the samples collected between October 28 and November 9, 2010, were omitted from the report because it was determined that the probe was malfunctioning. The minimum value of $-173 \mathrm{mV}$ for oxidationreduction potential was measured in the source-water sample collected from well LJ-65-20-126 in March 2010; such a relatively small oxidation-reduction potential indicates an environment favorable for the reduction of chemical species (Pankow, 1991). In contrast, the maximum positive value of $466 \mathrm{mV}$, measured in a source-water sample from well LJ-65-12-817 in March 2010, indicates a geochemical environment with a relatively large oxidizing tendency. In source-water samples with dissolved-oxygen concentrations less than the MRL of $0.1 \mathrm{mg} / \mathrm{L}$, oxidation-reduction potential measurements were all in the negative range.

The dissolved-solids concentrations (filtered residue on evaporation in milligrams per liter, dried at $180{ }^{\circ} \mathrm{C}$ ) ranged from 225 to $406 \mathrm{mg} / \mathrm{L}$ in the groundwater samples. Of the 47 sampled wells, the maximum dissolved-solids concentration was measured in a source-water sample collected from well JY-65-29-107, which also had the maximum specific conductance measurement of $724 \mu \mathrm{S} / \mathrm{cm}$, maximum chloride concentration of $80.8 \mathrm{mg} / \mathrm{L}$ and maximum sulfate concentration of 17.1 milligrams per liter (table 4). The minimum dissolved-solids concentration was measured in a source-water sample collected from well LJ-65-06-528, which also had the minimum specific conductance measurement of $439 \mu \mathrm{S} / \mathrm{cm}$ (table 4).

Similar to the results from the reconnaissance survey (Oden and others, 2010), the largest ranges in concentration for filtered major ion constituents were obtained for the cations sodium and calcium and for the anions chloride and sulfate. The ranges for these constituents are as follows: 30.5 to $110 \mathrm{mg} / \mathrm{L}$ for sodium, 14.4 to $69.7 \mathrm{mg} / \mathrm{L}$ for calcium, 29.0 to $80.8 \mathrm{mg} / \mathrm{L}$ for chloride, and 4.93 to $17.1 \mathrm{mg} / \mathrm{L}$ for sulfate (table 4).

\section{Arsenic and Other Trace Elements}

Arsenic concentrations measured in source-water samples from the 47 wells ranged from 1.6 to $23.5 \mu \mathrm{g} / \mathrm{L}$ (table 5). The maximum concentration of arsenic $(23.5 \mu \mathrm{g} / \mathrm{L})$ was measured 
in the source-water sample from well LJ-65-12-328 on March 17,2010 , which was the only source-water sample from a well with a measured concentration greater than $10 \mu \mathrm{g} / \mathrm{L}$.

To further characterize the water chemistry, the sourcewater samples collected from the 47 municipal supply wells that are documented in this report also were analyzed for other selected trace elements (barium, boron, chromium, iron, lithium, manganese, molybdenum, selenium, strontium, and vanadium) (table 5). The number of trace elements selected for analysis was reduced from 22 during the 2007-08 reconnaissance survey (Oden and others, 2010) to 11 in 2010. Based on the results from the reconnaissance survey, constituents that were not detected in many source-water samples were excluded from analysis in 2010. Quantifiable concentrations of barium, boron, lithium, molybdenum, and strontium were measured in all 47 filtered, source-water samples in 2010 (table 5). Quantifiable concentrations of manganese were measured in 46 source-water samples, and an estimated concentration of manganese was measured in 1 sample. Chromium, iron, selenium, and vanadium were detected in 24 or more of the 47 source-water samples (table 5). The ranges in concentration for those constituents detected in all 47 source-water samples are as follows: barium ranged from 150 to $411 \mu \mathrm{g} / \mathrm{L}$, boron ranged from 38 to $190 \mu \mathrm{g} / \mathrm{L}$, lithium ranged from 10.1 to $24 \mu \mathrm{g} / \mathrm{L}$, molybdenum ranged from 0.3 to $13.2 \mu \mathrm{g} / \mathrm{L}$, and strontium ranged from 316 to $738 \mu \mathrm{g} / \mathrm{L}$ (table 5). Manganese ranged from an estimated concentration of 0.2 to $56.3 \mu \mathrm{g} / \mathrm{L}$ (table 5).

\section{Radionuclides}

\section{Gross Alpha-Particle and Beta-Particle Activities}

Gross alpha-particle activities and beta-particle activities for all 47 source-water samples were analyzed 72 hours after sample collection and again 30 days after sample collection, allowing for the measurement of the activity of short-lived isotopes. These gross activity measurements represent the overall alpha-particle and beta-particle activity of all the radionuclides present in the sample in the given period of time associated with the measurement (U.S. Environmental Protection Agency, 1997). Gross alpha-particle activities reported for source-water samples were not adjusted (reduced) for activity contributions by radon or uranium and, therefore, are conservatively high estimates - an additional factor to keep in mind if the source-water results are compared to the USEPA National Primary Drinking Water Regulation for adjusted gross alpha-particle activity (U.S. Environmental Protection Agency, 2000) (table 1).

The gross alpha-particle activities measured at 30 days were greater than their associated $\mathrm{ssL}_{\mathrm{C}}$ for 46 of the 47 sourcewater samples collected. The gross alpha-particle activities measured at 30 days in the samples ranged from $\mathrm{R} 0.60$ to 25.5 $\mathrm{pCi} / \mathrm{L}$ (the " $\mathrm{R}$ " preceding the value of $0.60 \mathrm{pCi} / \mathrm{L}$ refers to a nondetected result less than the $\mathrm{ssL}_{\mathrm{C}}$ ) (table 6). The maximum gross alpha-particle activity at 30 days was measured in the source-water sample obtained from well LJ-65-04-723. The gross alpha-particle activities measured in all of the 47 sourcewater samples at 72 hours after sample collection were greater than their associated $\mathrm{ssL}_{\mathrm{C}}$. The gross alpha-particle activities at 72 hours ranged from 2.58 to $39.7 \mathrm{pCi} / \mathrm{L}$ (table 6). The maximum gross alpha-particle activity was measured at 72 hours in the source-water sample obtained from well LJ-6504-729. The laboratory assigned remark codes to several of the gross alpha-particle activity results to provide additional quality-control information for the interpretation of the results (table 6). Two of the gross alpha-particle activities measured at 30 days and one result measured at 72 hours had a remark code of " $b$ " to indicate that the associated ssMDC for these measurements was greater than the contractual a priori MDC, which is established by NWQL as a data quality objective for each radiological constituent as part of the performance work statement with the contract laboratory (table 6). Six of the gross alpha-particle activities measured at 30 days and 11 results measured at 72 hours had a remark code of "e" to indicate that the associated laboratory blank was greater than the $\mathrm{ssL}_{\mathrm{C}}$ and, therefore, a detectable concentration.

All of the 47 source-water samples collected had a gross beta-particle activity at 30 days greater than the associated $\mathrm{ssL}_{\mathrm{C}}$. Gross beta-particle activities at 30 days ranged from 1.17 to $14.4 \mathrm{pCi} / \mathrm{L}$ (table 6 ). The maximum gross-beta activity counted at 30 days of $14.4 \mathrm{pCi} / \mathrm{L}$ was measured in the sourcewater sample from well LJ-65-04-729. Gross beta-particle activities measured at 72 hours also were consistently greater than the associated $\mathrm{ssL}_{\mathrm{C}}$. Gross beta-particle activities at 72 hours ranged from 1.97 to $4.4 \mathrm{pCi} / \mathrm{L}$ (table 6 ). The maximum gross beta-particle activity at 72 hours of $4.4 \mathrm{pCi} / \mathrm{L}$ was measured in the source-water sample from well LJ-65-12-633. In addition to the beta-emitting isotopes in the uranium-238 and thorium-232 decay series, a substantial part of the gross betaparticle activity measurements in these source-water samples could be attributed to beta emissions from potassium-40, a weak beta emitter that occurs naturally (Hem, 1992). The potassium concentrations measured in source-water samples from the 47 wells ranged from 1.53 to $2.76 \mathrm{mg} / \mathrm{L}$ (table 4).

Twenty-six of the 47 sampled wells had similar grossalpha particle activities measured at the different time intervals, within plus or minus $5 \mathrm{pCi} / \mathrm{L}$ (table 6 ). Six of these 26 wells were within the uncertainty ranges defined by the associated 1-sigma CSU and, thus, the counts could not be differentiated within the associated analytical error. Although the gross alpha-particle measurements of radioactivity resulted in similar activity values in more than one-half of the samples, 35 of the 47 sampled wells had activity measurements (at 72 hours and 30 days) greater than the $\mathrm{ssL}_{\mathrm{C}}$, and the activity measured at 72 hours was greater than (outside their uncertainty ranges defined by their 1-sigma CSU) the activity measured at 30 days; and conversely, 5 of the 47 sampled wells had activity measurements (at 72 hours and 30 days) greater than the $\mathrm{ssL}_{\mathrm{C}}$ and the activity measured at 30 days was greater than (outside their 1-sigma CSU) the activity measured at 72 hours. For 
the gross alpha-particle activities measured at 30 days after sample collection, six source-water samples had an unadjusted gross alpha-particle activity greater than $15 \mathrm{pCi} / \mathrm{L}$. At 72 hours, 10 source-water samples had unadjusted gross alphaparticle activities equal to or greater than $14.8 \mathrm{pCi} / \mathrm{L}$ (table 6). Three of the wells sampled had unadjusted gross alpha-particle activities (at 72 hour and 30 days) greater than $15 \mathrm{pCi} / \mathrm{L}$. For the six source-water samples with a gross alpha-particle activity (at 30 days) greater than $15 \mathrm{pCi} / \mathrm{L}$, the uranium concentrations ranged from 0.12 to $42.7 \mu \mathrm{g} / \mathrm{L}$ (table 6 ). To convert a uranium concentration in micrograms per liter to an approximate radioactivity concentration in picocuries per liter, a conversion factor of $0.68 \mathrm{pCi} / \mathrm{L}$ is used, which is based on the assumption that the uranium-234 and uranium-238 are present in equal activities. This calculation is recognized as a conservative approximation of the uranium radioactivity because the activity ratio varies in groundwater from region to region (U.S. Environmental Protection Agency, 2000).

As with the reconnaissance survey in 2007-08 (Oden and others, 2010), the differences for the gross beta-particle activities measured at different time intervals in 2010 were not as pronounced as the differences for the gross alpha-particle activities measurements at 72 hours and 30 days. Twenty-nine of the 47 wells sampled had similar gross beta-particle activity measurements (at 72 hour and 30 days) within the uncertainty ranges defined by the associated 1-sigma CSU and, thus, the counts could not be differentiated within the associated analytical error (table 6).

\section{Uranium}

Filtered uranium was detected in amounts that could be quantified in all of the 47 wells sampled. The uranium concentrations ranged from 0.03 to $42.7 \mu \mathrm{g} / \mathrm{L}$ (table 6). The maximum concentration of $42.7 \mu \mathrm{g} / \mathrm{L}$ was measured in the source-water sample from LJ-65-04-729, which was the only source-water sample collected greater than $30 \mu \mathrm{g} / \mathrm{L}$.

\section{Other Radionuclides}

The source-water sample collected from one well (LJ65-12-328) was analyzed for carbon-14 (table 6). The amount of modern atmospheric carbon was reported as 0.2 percent. Modern is defined as 95 percent of the radiocarbon activity in 1950 , as defined by the standards used during analysis. The "radiocarbon" age is calibrated to this material of known age to correct for variations in the amount of carbon-14 produced in the atmosphere; these variations mostly result from the varying intensity of cosmic rays striking the upper atmosphere and fluctuations in the amount of carbon dioxide in the atmosphere (University of Arizona, 2010). Carbon-14 can be used as a tracer to determine the relative age of recharge of groundwater; because the half life of carbon-14 is 5,730 years, carbon-14 is useful for determining the age of groundwater that was recharged between about 1,000 and 30,000 years ago (Coplen, 1993; Hinkle, 2010).
Six source-water samples collected from municipal supply wells were analyzed for radium-226, and all of the concentrations were greater than their associated $\mathrm{ssL}_{\mathrm{C}}$. The radium-226 concentrations measured in the source-water samples ranged from 0.732 to $2.59 \mathrm{pCi} / \mathrm{L}$ (table 6). Three source-water samples were analyzed for radon-222, and all of the concentrations were substantially greater than the associated $\mathrm{ssL}_{\mathrm{C}}$. The radon-222 concentrations for the samples ranged from 1,620 to 2,380 pCi/L (table 6). Concentrations of radon-222 measured in source-water samples from all three wells were greater than $300 \mathrm{pCi} / \mathrm{L}$, and none of the concentrations measured in the samples exceeded 4,000 pCi/L.

\section{Summary}

During March-December 2010, the U.S. Geological Survey (USGS), in cooperation with the city of Houston, collected water-quality data from wells completed in the Gulf Coast aquifer system in the Houston area to characterize source-water-quality conditions in untreated groundwater prior to drinking-water treatment. These data were collected as part of an ongoing study to determine concentrations, spatial extent, and associated geochemical conditions that might be conducive for mobility and transport of selected naturally occurring contaminants (selected trace elements and radionuclides) in the Gulf Coast aquifer system in the Houston area. In the summers of 2007 and 2008, a reconnaissance-level survey of most of the same constituents measured in 2010 was completed by the USGS in cooperation with the city of Houston; the samples collected during 2007-08 were untreated water from 28 municipal supply wells in the Houston area. For the second phase of the study, source-water samples were collected from 60 municipal supply wells in the Houston area between March and December of 2010. Included in this report are the complete analytical results for 47 of the 60 samples collected in 2010 - those results which were received from the laboratories and reviewed by the authors as of December 31, 2010. Selected physicochemical (relating to both physical and chemical) properties and unfiltered sulfides were measured in the field at the time each sample was collected. Source-water samples were analyzed for major ions, selected chemically related properties, trace elements, and radionuclides. An evaluation of naturally-occurring contaminant occurrence in source water provides background information regarding the presence of a contaminant in the environment. Because source-water samples were collected prior to any treatment or blending that potentially could alter contaminant concentrations, the sampled groundwater represents the quality of the source water, not the quality of finished drinking water (water that has passed through all the treatment processes and is ready to be delivered to consumers through a community water system).

Of the 47 wells for which water-quality results are documented in this report, 22 were screened entirely in the Evangeline aquifer. The remaining 25 wells contained screened intervals that intersected the Evangeline and Chicot 
aquifers. Samples were collected and processed in accordance with protocols established by the USGS "National Field Manual for the Collection of Water-Quality Data." Prior to sample collection, each well was pumped continuously for at least 30 minutes to ensure that source-water sampled from the well was representative of water from the aquifer. Groundwater samples were collected as near to the wellhead as possible prior to treatment. The source-water samples were analyzed for a variety of physicochemical properties and constituents to characterize the water chemistry of the Gulf Coast aquifer system. Field measurements were made of selected physicochemical properties (oxidation-reduction potential, turbidity, dissolved-oxygen concentration, $\mathrm{pH}$, specific conductance, water temperature, and alkalinity) and unfiltered sulfides. Source-water samples also were analyzed for major ions (calcium, magnesium, potassium, sodium, bromide, chloride, fluoride, silica, and sulfate), residue on evaporation (dissolved solids), other selected trace elements (arsenic, barium, boron, chromium, iron, lithium, manganese, molybdenum, selenium, strontium, and vanadium), and selected radionuclides (gross alpha- and beta-particle activity [at 30 days and 72 hours], carbon-14, radium-226, radon-222, and uranium).

The physicochemical properties, major ion chemistry and trace element chemistry of the groundwater sampled in 2010, varied widely between the wells; results from the 47 wells sampled in 2010 documented in this report are similar to the results from the reconnaissance survey during 2007-08. The range of selected physicochemical properties for the 47 wells sampled in 2010 were as follows: oxidation-reduction potential ranged from -173 to 466 millivolts $(\mathrm{mV})$, dissolved oxygen ranged from less than 0.1 to 4.4 milligrams per liter (mg/L), $\mathrm{pH}$ ranged from 7.2 to 7.8 , specific conductance ranged from 439 to 724 microsiemens per centimeter at 25 ${ }^{\circ} \mathrm{C}(\mu \mathrm{S} / \mathrm{cm})$, and alkalinity ranged from 159 to $276 \mathrm{mg} / \mathrm{L}$ as calcium carbonate $\left(\mathrm{CaCO}_{3}\right)$. The largest ranges in concentration for filtered major ion constituents were obtained for cations sodium and calcium and for anions chloride and sulfate. Arsenic concentrations measured in source-water samples from the 47 wells ranged from 1.6 to 23.5 micrograms per liter $(\mu \mathrm{g} / \mathrm{L})$. The maximum concentration of arsenic $(23.5 \mu \mathrm{g} / \mathrm{L})$ was measured in the source-water sample from well LJ-65-12-328, which was the only source-water sample from a well with a measured concentration greater than 10 $\mu \mathrm{g} / \mathrm{L}$. Quantifiable concentrations of barium, boron, lithium, molybdenum, and strontium were measured in all 47 filtered samples. Quantifiable concentrations of manganese were measured in 46 source-water samples, and an estimated concentration of manganese was measured in 1 sample. Chromium, iron, selenium, and vanadium were detected in 24 or more of the 47 source-water samples. The ranges in concentration for those constituents detected in all 47 source-water samples are as follows: barium ranged from 150 to $411 \mu \mathrm{g} / \mathrm{L}$, boron ranged from 38 to $190 \mu \mathrm{g} / \mathrm{L}$, lithium ranged from 10.1 to $24 \mu \mathrm{g} / \mathrm{L}$, molybdenum ranged from 0.3 to $13.2 \mu \mathrm{g} / \mathrm{L}$, and strontium ranged from 316 to $738 \mu \mathrm{g} / \mathrm{L}$.
Manganese ranged from an estimated concentration of 0.2 to $56.3 \mu \mathrm{g} / \mathrm{L}$.

Gross alpha-particle activities and beta-particle activities for all 47 source-water samples were analyzed at 72 hours after sample collection and again at 30 days after sample collection, allowing for the measurement of the activity of short-lived isotopes. Gross alpha-particle activities reported in this study were not adjusted (reduced) for activity contributions by radon or uranium and, therefore, are conservatively high estimates if compared to the U.S. Environmental Protection Agency (USEPA) National Primary Drinking Water Regulation for adjusted gross alphaparticle activity. The unadjusted gross alpha-particle activities measured at 30 days in the source-water samples ranged from $\mathrm{R} 0.60$ to 25.5 picocuries per liter ( $\mathrm{pCi} / \mathrm{L}$ ) and at 72 hours ranged from 2.58 to $39.7 \mathrm{pCi} / \mathrm{L}$ (the " $\mathrm{R}$ " preceding the value of $0.60 \mathrm{pCi} / \mathrm{L}$ refers to a nondetected result less than the sample-specific critical level $\left.\left[\mathrm{ssL}_{\mathrm{C}}\right]\right)$. Gross beta-particle activities measured at 30 days ranged from 1.17 to $14.4 \mathrm{pCi} / \mathrm{L}$ and at 72 hours ranged from 1.97 to $4.4 \mathrm{pCi} / \mathrm{L}$. Twenty-six of the 47 sampled wells had similar gross-alpha particle activities measured at the different time intervals, within plus or minus $5 \mathrm{pCi} / \mathrm{L}$. Six of these 26 wells were within the uncertainty ranges defined by the associated 1-sigma standard uncertainty (CSU) and, thus, the counts could not be differentiated within the associated analytical error. For the unadjusted gross alphaparticle activities measured at 30 days after sample collection, six source-water samples had an unadjusted gross alpha-particle activity greater than $15 \mathrm{pCi} / \mathrm{L}$. At 72 hours, 10 source-water samples had unadjusted gross alpha-particle activities equal to or greater than $14.8 \mathrm{pCi} / \mathrm{L}$. Filtered uranium was detected in amounts that could be quantified in all of the 47 wells sampled. The uranium concentrations ranged from 0.03 to $42.7 \mu \mathrm{g} / \mathrm{L}$. The maximum concentration of $42.7 \mu \mathrm{g} / \mathrm{L}$ was measured in the source water sample from LJ-65-04-729, which was the only source-water sample collected greater than $30 \mu \mathrm{g} / \mathrm{L}$. The source-water sample collected from one well (LJ-65-12-328) was analyzed for carbon-14. The amount of modern atmospheric carbon was reported as 0.2 percent. Six source-water samples collected from municipal supply wells were analyzed for radium-226, and all of the concentrations were greater than their associated $\mathrm{ssL}_{\mathrm{C}}$. Three sourcewater samples collected were analyzed for radon-222, and all of the concentrations were substantially greater than their associated $\mathrm{ssL}_{\mathrm{C}}$. Concentrations of radon-222 measured in source-water samples from all three wells were greater than $300 \mathrm{pCi} / \mathrm{L}$, and none of the concentrations measured in the samples exceeded 4,000 $\mathrm{pCi} / \mathrm{L}$.

\section{References}

American Public Health Association, American Water Works Association, and Water Pollution Control Federation, 2005, Standard methods for the examination of water and 
wastewater (21st ed.): Washington, D.C., American Public Health Association, [variously paged].

ASTM International, 2006a, D1193-06, Standard specification for reagent water: ASTM International, accessed November 17, 2009, at http://www.astm.org/Standards/D1193.htm.

ASTM International, 2006b, D5072-98, Standard test method for radon in drinking water: ASTM International, accessed August 20, 2008, at http://www.astm.org.

Baker, E.T., Jr., 1979, Stratigraphic and hydrogeologic framework of part of the Coastal Plain of Texas: Texas Department of Water Resources Report 236, 43 p.

CHEMetrics, 2008, Operator's manual V-2000 photometer (Rev. 7): CHEMetrics Inc., 21 p.

Childress, C.J.O., Foreman, W.T., Connor, B.F., and Maloney, T.J., 1999, New reporting procedures based on long-term method detection levels and some considerations for interpretations of water-quality data provided by the U.S. Geological Survey National Water Quality Laboratory: U.S. Geological Survey Open-File Report 99-193, 19 p.

Chowdhury, A.H., Boghici, Radu, and Hopkins, Janie, 2006, Hydrochemistry, salinity distribution, and trace constituents-Implications for salinity sources, geochemical evolution, and flow systems characterization, Gulf Coast aquifer, Texas, in Mace, R.E., Davidson, S.C., Angle, E.S., and Mullican, W.F., eds., Aquifers of the Gulf Coast of Texas: Texas Water Development Board Report 365, p. 81-128.

Coplen, T.B., 1993, Uses of environmental isotopes, in Alley, W.M., ed., Regional ground-water quality: New York, Van Nostrand Reinhold, p. 227-254.

Currie, L.A., 1968, Limits for qualitative detection and quantitative determination-Application to radiochemistry: Analytical Chemistry, v. 20, p. 586-593.

DeSimone, L.A., 2009, Quality of water from domestic wells in principal aquifers of the United States, 1991-2004: U.S. Geological Survey Scientific Investigations Report 20085227, 139 p., accessed September 25, 2010, at http://pubs. usgs.gov/sir/2008/5227.

Faires, L.M., 1993, Methods of analysis by the U.S. Geological Survey National Water Quality LaboratoryDetermination of metals in water by inductively coupled plasma-mass spectrometry: U.S. Geological Survey OpenFile Report 92-634, 28 p.

Fishman, M.J., ed., 1993, Methods of analysis by the U.S. Geological Survey National Water Quality LaboratoryDetermination of inorganic and organic constituents in water and fluvial sediments: U.S. Geological Survey OpenFile Report 93-125, 217 p.

Focazio, M.J., Welch, A.H., Watkins, S.A., Helsel, D.R., and Horn, M.A., 2000, A retrospective analysis on the occurrence of arsenic in ground-water resources of the United
States and limitations in drinking-water-supply characterizations: U.S. Geological Survey Water-Resources Investigations Report 99-4279, 21 p.

Focazio, M.J., Szabo, Zoltan, Kraemer, T.F., Mullin, A.H., Barringer, T.H., and dePaul, V.T., 2001, Occurrence of selected radionuclides in ground water used for drinking water in the United States-A reconnaissance survey, 1998: U.S. Geological Survey Water-Resources Investigations Report 00-4273, 39 p.

Garbarino, J.R., 1999, Methods of analysis by the U.S. Geological Survey National Water Quality LaboratoryDetermination of dissolved arsenic, boron, lithium, selenium, strontium, thallium, and vanadium using inductively coupled plasma-mass spectrometry: U.S. Geological Survey Open-File Report 99-093, 31 p.

Garbarino, J.R., Kanagy, L.K., and Cree, M.E., 2006, Determination of elements in natural-water, biota, sediment and soil samples using collision/reaction cell inductively coupled plasma-mass spectrometry: U.S. Geological Survey Techniques and Methods, book 5, sec. B, chap. 1, 88 p.

Hall, F.R., Donahue, P.M., and Eldridge, A.L., 1985, Radon gas in ground water in New Hampshire: National Water Well Association Proceedings of the Second Annual Eastern Regional Ground Water Conference, Worthington, Ohio, p.86-100.

Hansen, H.J., 1971, Transmissivity tracts in the Coastal Plain aquifers of Maryland: Southeastern Geology, v. 13, p. 127-149.

Hem, H.D., 1992, Study and interpretation of the chemical characteristics of natural water: U.S. Geological Survey Water-Supply Paper 2254, 264 p.

Hinkle, S.R., 2010, Age of groundwater: Water Encyclopedia, accessed August 9, 2010, at http://www.waterencyclopedia. com/Ge-Hy/Groundwater-Age-of.html.

Hopple, J.A., Delzer, G.C., and Kingsbury, J.A., 2009, Anthropogenic organic compounds in source water of selected community water systems that use groundwater, 2002-05: U.S. Geological Survey Scientific Investigations Report 2009-5200, 74 p.

Horowitz, A.J., Lum, K.R., Garbarino, J.R., Hall, G.E.M., LeMieux, C., and Demas, C.R., 1996, Problems associated with using filtration to define dissolved trace element concentrations in natural water samples: Environmental Science Technology, v. 30, no. 3, p. 954-963.

Kasmarek, M.C., Johnson, M.R., and Ramage, J. R., 2010, Water-level altitudes 2010 and water-level changes in the Chicot, Evangeline, and Jasper aquifers and compaction 1973-2009 in the Chicot and Evangeline Aquifers, Houston-Galveston region, Texas: U.S. Geological Survey Scientific Investigations Map 3138, 17 p., 16 sheets, 1 appendix. 
Lewis, M.E., June 2006, Dissolved oxygen (version 2.1): U.S. Geological Survey Techniques of Water-Resources Investigations, book 9, chap. A6, sec. 6.2, accessed August 20, 2008, at http://pubs.water.usgs.gov/twri9A6/.

McCurdy, D.E., Garbarino, J.R., and Mullin, A.H., 2008, Interpreting and reporting radiological water-quality data: U.S. Geological Survey Techniques and Methods, book 5, chap. B6, 33 p.

Michel, T.A., 2006, 100 years of groundwater use and subsidence in the upper Texas Gulf Coast, in Mace, R.E., Davidson, S.C., Angle, E.S., and Mullican, W.F., eds., Aquifers of the Gulf Coast of Texas: Texas Water Development Board Report 365, chap. 7, p. 139-148.

National Research Council, 1999, Arsenic in drinking water: Washington, D.C., National Academy Press, 273 p.

Oden, J.H., Oden, T.O., and Szabo, Zoltan, 2010, Groundwater quality of the Gulf Coast aquifer system, Houston, Texas, 2007-08: U.S. Geological Survey Data Series 548, 65 p.

Pankow, J.F., 1991, Aquatic chemistry concepts: Chelsea, Mich., Lewis Publishers, 683 p.

Parsa, Bahman, 1998, Contribution of short-lived radionuclides to alpha-particle radioactivity in drinking water and their impact on the Safe Drinking Water Act Regulations: Radioactivity and Radiochemistry, v. 9, no. 4, p. 41-50.

Renken, R.A., 1998, Ground water atlas of the United States-Segment 5, Arkansas, Louisiana, and Mississippi: U.S. Geological Survey Hydrologic Atlas 730-F, accessed August 20, 2008, at http://capp.water.usgs.gov/gwa/ch_f/ F-text3.html.

Rounds, S.A., 2006, Alkalinity and acid neutralizing capacity (version 3.0): U.S. Geological Survey Techniques of Water Resources Investigations, book 9, chap. A6., section 6.6, accessed February 11, 2011, at http://pubs.water.usgs.gov/ twri9A6/.

Ryder, P.D., 1996, Ground water atlas of the United States: Segment 4, Oklahoma, Texas: U.S. Geological Survey Hydrologic Atlas 730-E, accessed August 20, 2008, at http://capp.water.usgs.gov/gwa/ch_e/E-text6.html.

Ryder, P.D., and Ardis, A.F., 2002, Hydrology of the Texas Gulf Coast aquifer systems: U.S. Geological Survey Professional Paper 1416-E, 77 p.

Ryker, S.J., 2003, Arsenic in ground water used for drinking water in the United States, in Welch, A.H., and Stollenwerk, K.G., eds., Arsenic in ground water geochemistry and occurrence: Amsterdam, Kluwer Academic Publishers, p. $165-178$.

Sugarman, P.J., and Miller, K.G., 1997, Correlation of Miocene sequences and hydrogeologic units, New Jersey Coastal Plain: Sedimentary Geology, v. 108, p. 3-18.
Szabo, Zoltan, and dePaul, V.T., 1998, Radium-226 and radium-228 in shallow ground water, southern New Jersey: U.S. Geological Survey Fact Sheet FS-062-98, 6 p.

Szabo, Zoltan, dePaul, V.T., and Parsa, Bahman, 1998, Decrease in gross alpha-particle activity in water samples with time after collection from the Kirkwood-Cohansy aquifer system in southern New Jersey: Implications for drinking water regulations: 63rd annual meeting, American Water Works Association, New Jersey section, Atlantic City, N.J., March 26-27, 1998 [abs.].

Szabo, Zoltan, dePaul, V.T., Kraemer, T.F., and Parsa, Bahman, 2005, Occurrence of radium-224, radium-226, and radium-228 in water of the unconfined Kirkwood-Cohansey aquifer system, southern New Jersey: U.S. Geological Survey Scientific Investigations Report 2004-5224, 84 p. (Also available at http://pubs.usgs.gov/sir/2004/5224.)

Texas State Data Center, 2010, Estimates of the total population of counties and places in Texas for July 1, 2009 and January 1, 2010: Texas Population Estimates and Projections Program, accessed February 11, 2011, at http://txsdc.utsa.edu/tpepp/2009_txpopest_msa.php.

Toccalino, P.L., Norman, J.E., and Hitt, K.J., 2010, Quality of source water from public-supply wells in the United States, 1993-2007: U.S. Geological Survey Scientific Investigations Report 2010-5024, 209 p.

Troyer, G.L., Jones, R.A., and Jensen, Louis, 1991, The utility of reporting negative counting values: Radioactivity and Radiochemistry, v. 2, no. 1, p. 48-56.

University of Arizona, 2010, Accelerator mass spectrometry laboratory, basic principles of radiocarbon dating: accessed September 15, 2010, at http://www.physics.arizona.edu/ ams/education/theory.htm.

U.S. Environmental Protection Agency, 1997, National primary drinking water regulations-Analytical methods for radionuclides: Federal Register, v. 62, no. 43, p. $10,168-10,175$.

U.S. Environmental Protection Agency, 1999, National primary drinking water regulations-Radon-222; Proposed Rule 40 CFR Parts 141 and 142: Washington D.C., Federal Register, v. 64, no. 211, p. 59,245-59,294.

U.S. Environmental Protection Agency, 2000, National primary drinking water regulations-Radionuclides; Final Rule 40 CFR Parts 9, 141, and 142: Washington, D.C., Federal Register, v. 65, no. 236, p. 76,708-76,753.

U.S. Environmental Protection Agency, 2001, National primary drinking water regulations-Arsenic and clarification to compliance and new source contaminants monitoring; Final Rule 40 CFR Parts 141 and 142: Washington, D.C., Federal Register, v. 66, no. 14, p. 6,975-7,066.

U.S. Environmental Protection Agency, 2004, Understanding the safe drinking water act: U.S. Environmental Protection 
Agency, Office of Water EPA 816-F-04-030, June 2004, 4 p. Available at http://water.epa.gov/lawsregs/guidance/ sdwa/upload/2009_08_28_sdwa_fs_30ann_sdwa_web.pdf.

U.S. Environmental Protection Agency, 2008, Analytical methods approved for drinking water compliance monitoring of radionuclides: accessed August 20, 2008, at http://www.epa.gov/safewater/methods/pdfs/methods/ methods_radionuclides.pdf.

U.S. Environmental Protection Agency, 2011, Drinking Water Contaminants, National Primary Drinking Water Regulations: accessed February, 2011, at http://waterepa. gov/drink/contaminants/index.cfm.

U.S. Geological Survey, 2009, User's manual for the National Water Information System of the U.S. Geological SurveyWater-quality system (version 4.9): accessed November 18, 2009, at http://nwis.usgs.gov/nwisdocs4_9/qw/QW.user. book.html.

U.S. Geological Survey, 2010a, National Water Quality Laboratory-Quality: accessed August 25, 2010, at http://nwql.usgs.gov/Public/quality.shtml.

U.S. Geological Survey, 2010b, Office of Water Quality Technical Memorandum 2010.07: accessed January 26,
2011, at http://water.usgs.gov/admin/memo/QW/qw10.07. html.

U.S. Geological Survey, variously dated, National field manual for the collection of water-quality data: U.S. Geological Survey Techniques of Water-Resources Investigations, book 9, chaps. A1-A9, accessed September 27, 2010, at http://pubs.water.usgs.gov/twri9A.

Welch, A.H., Westjohn, D.B., Helsel, D.R., and Wanty, R.B., 2000, Arsenic in ground water of the United StatesOccurrence and geochemistry: Ground Water, v. 38, no. 4, p. 589-604

Wilde, F.D., 2008, General information and guidelines (version 2.0): U.S. Geological Survey Techniques of Water Resources Investigations, book 9, chap. A6., section 6.0, accessed February 11, 2011, at http://pubs.water.usgs.gov/ twri9A6/.

Zapecza, O.S., and Szabo, Zoltan, 1988, Natural radioactivity in ground water-A review, in National Water Summary 1986-Ground water quality: Hydrologic conditions and events: U.S. Geological Survey Water-Supply Paper 2325, p. 50-57. 
Table 2. Well information for municipal supply wells sampled in the Houston, Texas, area, 2010.

[ft bls, feet below land surface; 112CEVG, Chicot and Evangeline aquifers; --, no data available; 121EVGL, Evangeline aquifer; SNCL; sand with some clay; SDCL, sand clay; CLSD, clay sand]

\begin{tabular}{|c|c|c|c|c|c|c|c|c|}
\hline $\begin{array}{l}\text { U.S. Geological } \\
\text { Survey site number }\end{array}$ & $\begin{array}{l}\text { State well } \\
\text { number }\end{array}$ & County & $\begin{array}{l}\text { Well depth } \\
\text { (ft bls) }\end{array}$ & $\begin{array}{c}\text { Depth to } \\
\text { top of open } \\
\text { interval } \\
\text { (ft bls) }\end{array}$ & $\begin{array}{c}\text { Depth to } \\
\text { bottom of } \\
\text { open interval } \\
\text { (ft bls) }\end{array}$ & $\begin{array}{c}\text { Date of } \\
\text { construction }\end{array}$ & $\begin{array}{l}\text { Aquifer } \\
\text { code }\end{array}$ & $\begin{array}{l}\text { Lithology } \\
\text { code }\end{array}$ \\
\hline & & & & 448 & 496 & & & \\
\hline & & & & 524 & 554 & & & \\
\hline & & & & 650 & 660 & & & \\
\hline & & & & 680 & 710 & & & \\
\hline \multirow[t]{8}{*}{294900095312101} & LJ-65-12-619 & Harris & 1,451 & 630 & 640 & $1 / 1 / 1964^{1}$ & $112 \mathrm{CEVG}$ & -- \\
\hline & & & & 935 & 1,000 & & & \\
\hline & & & & 1,040 & 1,055 & & & \\
\hline & & & & 1,075 & 1,090 & & & \\
\hline & & & & 1,165 & 1,200 & & & \\
\hline & & & & 1,240 & 1,270 & & & \\
\hline & & & & 1,315 & 1,335 & & & \\
\hline & & & & 1,365 & 1,440 & & & \\
\hline \multirow[t]{3}{*}{295027095312301} & LJ-65-12-328 & Harris & 1,475 & 1,062 & 1,090 & 10/27/1996 & 121EVGL & -- \\
\hline & & & & 1,388 & 1,404 & & & \\
\hline & & & & 1,426 & 1,450 & & & \\
\hline \multirow[t]{11}{*}{294950095313701} & LJ-65-12-622 & Harris & 1,485 & 610 & 680 & $1 / 1 / 1968^{1}$ & $112 \mathrm{CEVG}$ & -- \\
\hline & & & & 724 & 744 & & & \\
\hline & & & & 767 & 797 & & & \\
\hline & & & & 838 & 888 & & & \\
\hline & & & & 945 & 978 & & & \\
\hline & & & & 1,010 & 1,020 & & & \\
\hline & & & & 1,130 & 1,175 & & & \\
\hline & & & & 1,188 & 1,245 & & & \\
\hline & & & & 1,278 & 1,298 & & & \\
\hline & & & & 1,330 & 1,375 & & & \\
\hline & & & & 1,440 & 1,470 & & & \\
\hline
\end{tabular}


Table 2. Well information for municipal supply wells sampled in the Houston, Texas, area, 2010_Continued.

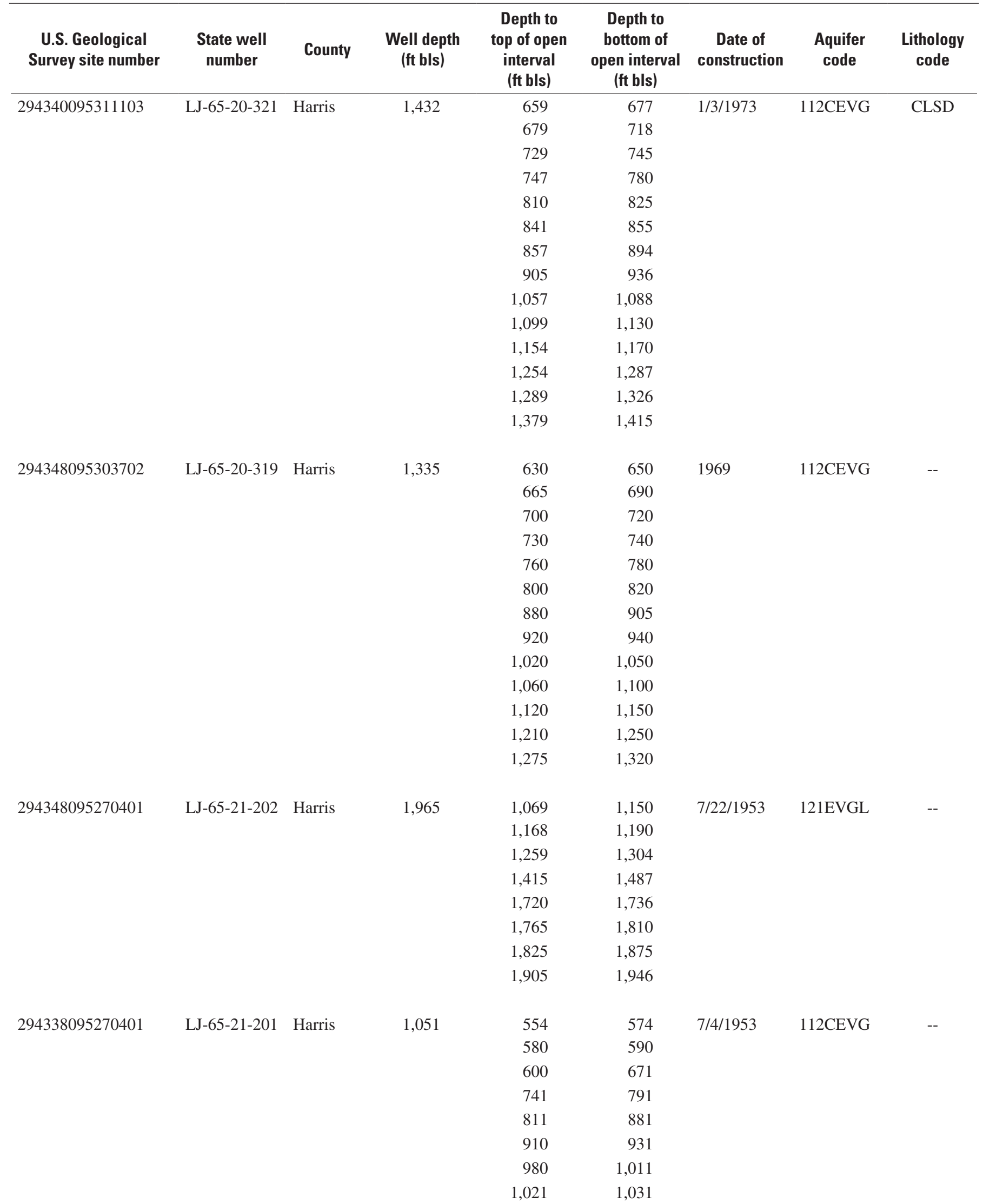


Table 2. Well information for municipal supply wells sampled in the Houston, Texas, area, 2010-Continued.

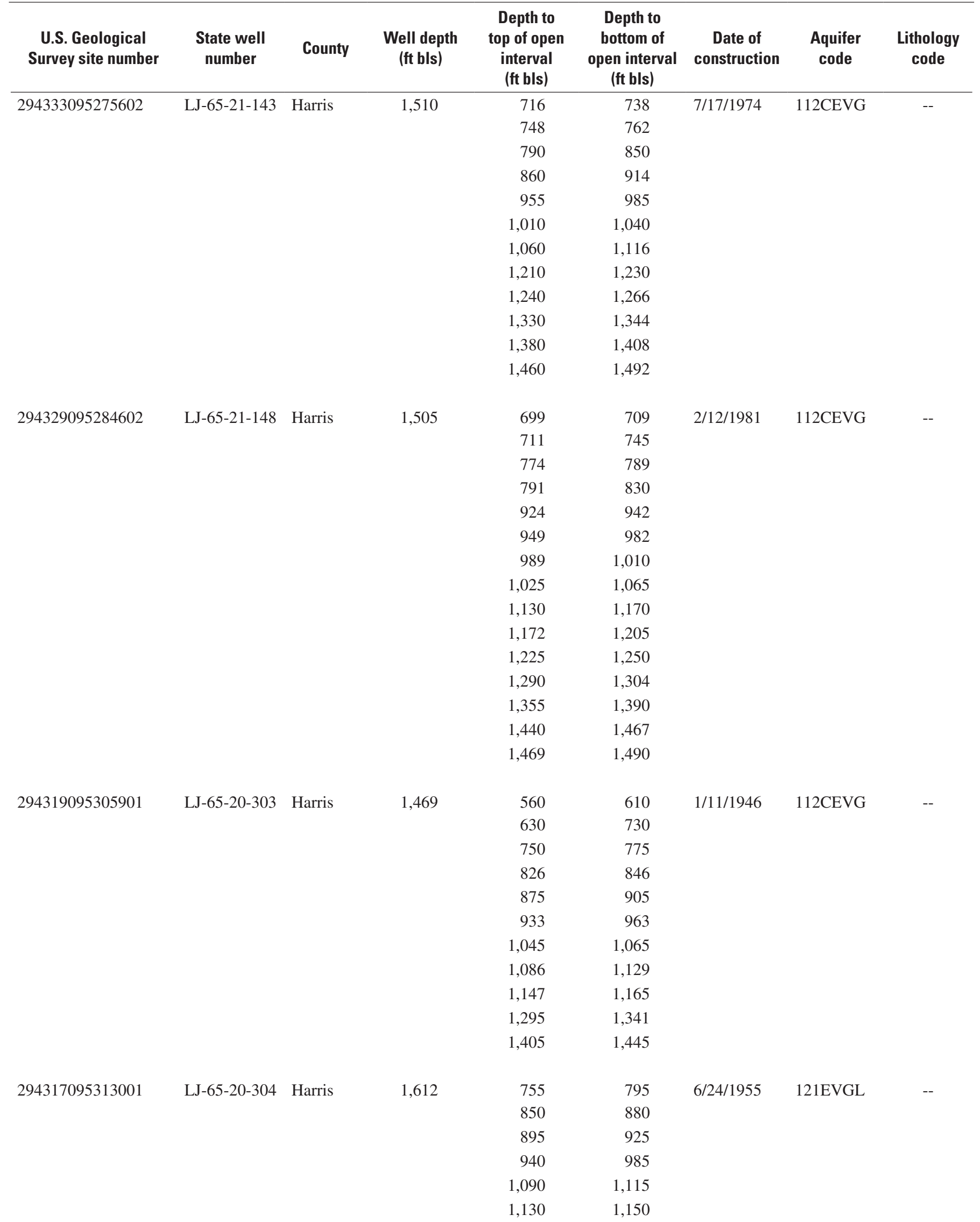


22 Groundwater Quality of the Gulf Coast Aquifer System, Houston, Texas, 2010

Table 2. Well information for municipal supply wells sampled in the Houston, Texas, area, 2010-Continued.

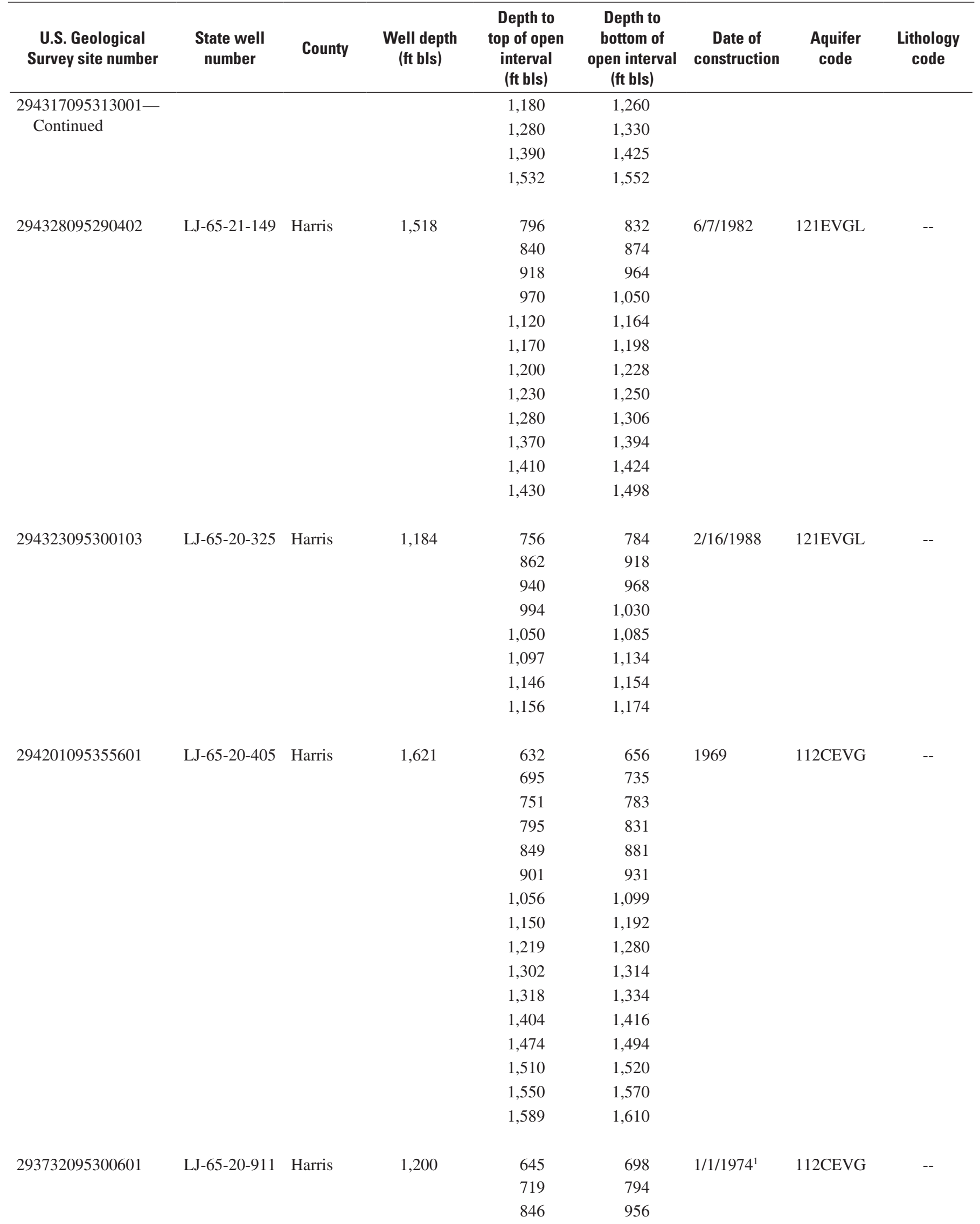


Table 2. Well information for municipal supply wells sampled in the Houston, Texas, area, 2010—Continued.

\begin{tabular}{|c|c|c|c|c|c|c|c|c|}
\hline $\begin{array}{l}\text { U.S. Geological } \\
\text { Survey site number }\end{array}$ & $\begin{array}{l}\text { State well } \\
\text { number }\end{array}$ & County & $\begin{array}{l}\text { Well depth } \\
\text { (ft bls) }\end{array}$ & $\begin{array}{c}\text { Depth to } \\
\text { top of open } \\
\text { interval } \\
\text { (ft bls) }\end{array}$ & $\begin{array}{c}\text { Depth to } \\
\text { bottom of } \\
\text { open interval } \\
\text { (ft bls) }\end{array}$ & $\begin{array}{c}\text { Date of } \\
\text { construction }\end{array}$ & $\begin{array}{l}\text { Aquifer } \\
\text { code }\end{array}$ & $\begin{array}{l}\text { Lithology } \\
\text { code }\end{array}$ \\
\hline \multirow{2}{*}{$\begin{array}{l}293732095300601- \\
\text { Continued }\end{array}$} & & & & 1,012 & 1,072 & & & \\
\hline & & & & 1,082 & 1,188 & & & \\
\hline \multirow{11}{*}{293734095293701} & & & & 653 & 688 & & & \\
\hline & & & & 698 & 733 & & & \\
\hline & & & & 735 & 767 & & & \\
\hline & & & & 770 & 803 & & & \\
\hline & & & & 828 & 868 & & & \\
\hline & & & & 1,010 & 1,039 & & & \\
\hline & & & & 1,042 & 1,080 & & & \\
\hline & & & & 1,082 & 1,096 & & & \\
\hline & & & & 1,106 & 1,118 & & & \\
\hline & & & & 1,120 & 1,158 & & & \\
\hline & & & & 1,160 & 1,182 & & & \\
\hline \multirow[t]{9}{*}{293736095285301} & LJ-65-21-709 & Harris & 1,190 & 644 & 679 & $9 / 1 / 1972^{1}$ & $112 \mathrm{CEVG}$ & -- \\
\hline & & & & 681 & 698 & & & \\
\hline & & & & 708 & 718 & & & \\
\hline & & & & 918 & 956 & & & \\
\hline & & & & 1,016 & 1,032 & & & \\
\hline & & & & 1,034 & 1,070 & & & \\
\hline & & & & 1,073 & 1,109 & & & \\
\hline & & & & 1,111 & 1,148 & & & \\
\hline & & & & 1,151 & 1,169 & & & \\
\hline \multirow[t]{8}{*}{294002095351001} & LJ-65-20-414 & Harris & 1,038 & 709 & 739 & $12 / 1 / 1978^{1}$ & $112 \mathrm{CEVG}$ & -- \\
\hline & & & & 748 & 760 & & & \\
\hline & & & & 774 & 799 & & & \\
\hline & & & & 810 & 844 & & & \\
\hline & & & & 850 & 880 & & & \\
\hline & & & & 899 & 969 & & & \\
\hline & & & & 984 & 994 & & & \\
\hline & & & & 1,008 & 1,028 & & & \\
\hline \multirow[t]{3}{*}{294414095364202} & LJ-65-20-126 & Harris & 1,322 & 970 & 1,025 & $8 / 20 / 1983$ & 121EVGL & -- \\
\hline & & & & 1,060 & 1,125 & & & \\
\hline & & & & 1,130 & 1,203 & & & \\
\hline
\end{tabular}


24 Groundwater Quality of the Gulf Coast Aquifer System, Houston, Texas, 2010

Table 2. Well information for municipal supply wells sampled in the Houston, Texas, area, 2010_Continued.

\begin{tabular}{|c|c|c|c|c|c|c|c|c|}
\hline $\begin{array}{l}\text { U.S. Geological } \\
\text { Survey site number }\end{array}$ & $\begin{array}{l}\text { State well } \\
\text { number }\end{array}$ & County & $\begin{array}{l}\text { Well depth } \\
\text { (ft bls) }\end{array}$ & $\begin{array}{l}\text { Depth to } \\
\text { top of open } \\
\text { interval } \\
\text { (ft bls) }\end{array}$ & $\begin{array}{c}\text { Depth to } \\
\text { bottom of } \\
\text { open interval } \\
\text { (ft bls) }\end{array}$ & $\begin{array}{c}\text { Date of } \\
\text { construction }\end{array}$ & $\begin{array}{l}\text { Aquifer } \\
\text { code }\end{array}$ & $\begin{array}{l}\text { Lithology } \\
\text { code }\end{array}$ \\
\hline \multirow[t]{2}{*}{ Continued } & & & & 1,260 & 1,280 & & & \\
\hline & & & & 1,300 & 1,322 & & & \\
\hline 294456095341101 & & & & 752 & 1,345 & & & \\
\hline \multirow[t]{3}{*}{294501095343601} & LJ-65-12-817 & Harris & 967 & 597 & 637 & $4 / 1 / 1979^{1}$ & $112 \mathrm{CEVG}$ & -- \\
\hline & & & & 654 & 732 & & & \\
\hline & & & & 748 & 772 & & & \\
\hline \multirow[t]{7}{*}{294519095383201} & LJ-65-11-918 & Harris & 1,316 & 550 & 690 & $7 / 20 / 1983$ & $112 \mathrm{CEVG}$ & -- \\
\hline & & & & 752 & 788 & & & \\
\hline & & & & 810 & 860 & & & \\
\hline & & & & 890 & 920 & & & \\
\hline & & & & 940 & 1,054 & & & \\
\hline & & & & 1,070 & 1,100 & & & \\
\hline & & & & 1,130 & 1,152 & & & \\
\hline \multirow[t]{12}{*}{295246095351301} & LJ-65-04-723 & Harris & 1,509 & 599 & 613 & $6 / 5 / 1982$ & $112 \mathrm{CEVG}$ & -- \\
\hline & & & & 861 & 873 & & & \\
\hline & & & & 903 & 915 & & & \\
\hline & & & & 951 & 995 & & & \\
\hline & & & & 1,013 & 1,041 & & & \\
\hline & & & & 1,079 & 1,127 & & & \\
\hline & & & & 1,135 & 1,158 & & & \\
\hline & & & & 1,192 & 1,225 & & & \\
\hline & & & & 1,261 & 1,272 & & & \\
\hline & & & & 1,355 & 1,367 & & & \\
\hline & & & & 1,401 & 1,413 & & & \\
\hline & & & & 1,431 & 1,489 & & & \\
\hline \multirow[t]{6}{*}{295249095364701} & LJ-65-04-728 & Harris & 1,438 & 825 & 858 & $7 / 11 / 1985$ & 121EVGL & SNCL \\
\hline & & & & 950 & 974 & & & \\
\hline & & & & 982 & 998 & & & \\
\hline & & & & 1,012 & 1,062 & & & \\
\hline & & & & 1,121 & 1,132 & & & \\
\hline & & & & 1,174 & 1,188 & & & \\
\hline
\end{tabular}


Table 2. Well information for municipal supply wells sampled in the Houston, Texas, area, 2010—Continued.

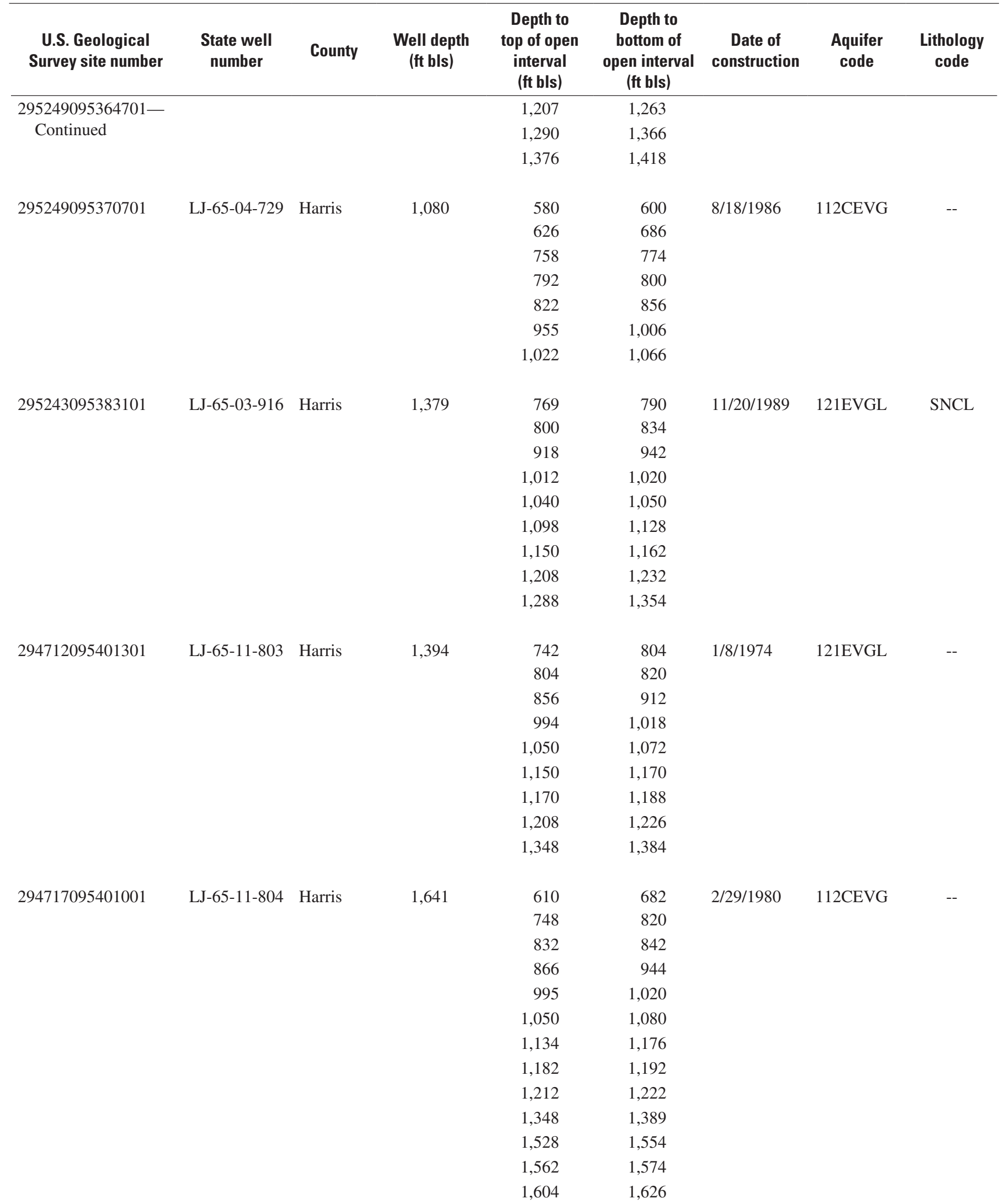


Table 2. Well information for municipal supply wells sampled in the Houston, Texas, area, 2010_Continued.

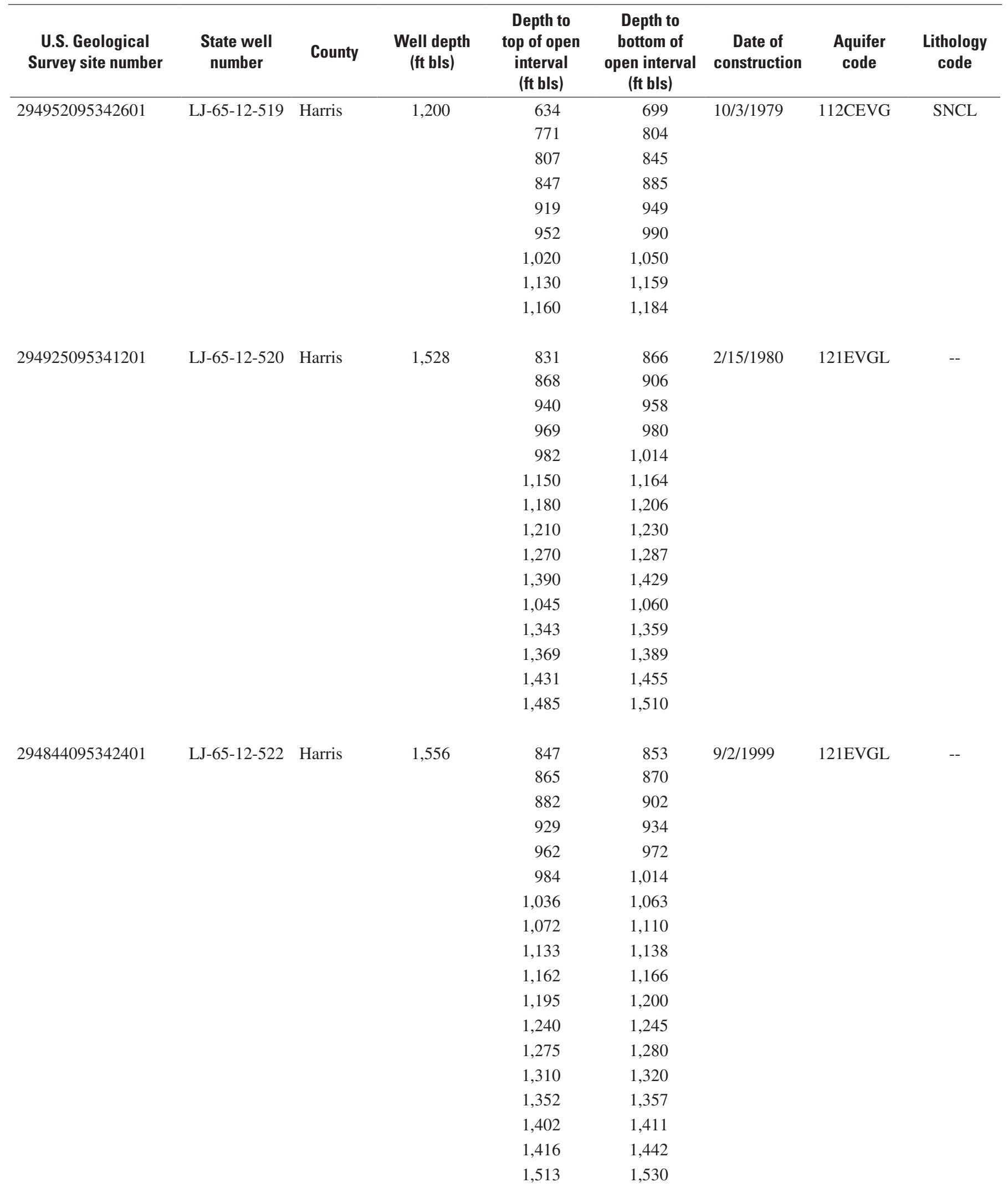


Table 2. Well information for municipal supply wells sampled in the Houston, Texas, area, 2010-Continued.

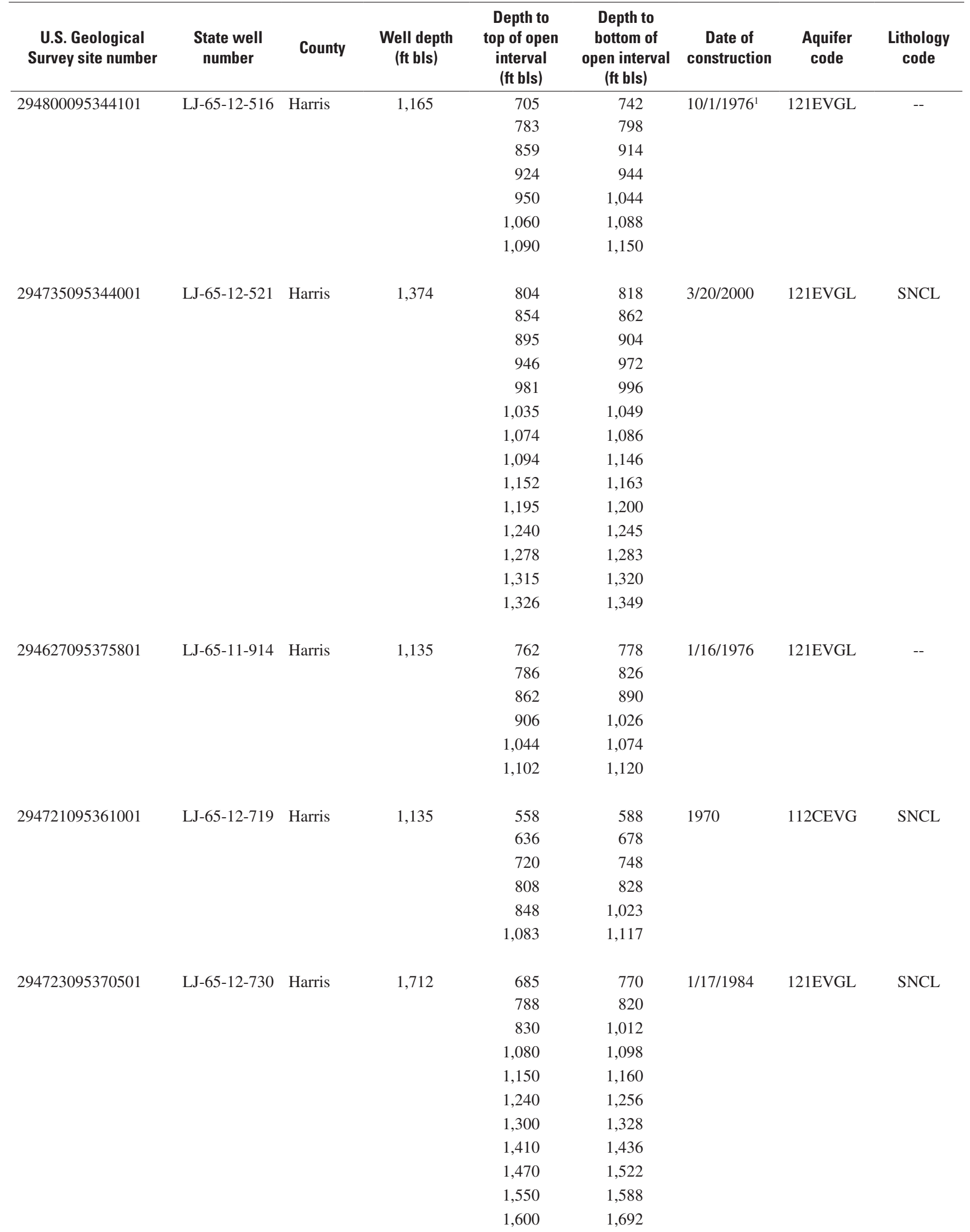


28 Groundwater Quality of the Gulf Coast Aquifer System, Houston, Texas, 2010

Table 2. Well information for municipal supply wells sampled in the Houston, Texas, area, 2010_Continued.

\begin{tabular}{|c|c|c|c|c|c|c|c|c|}
\hline $\begin{array}{l}\text { U.S. Geological } \\
\text { Survey site number }\end{array}$ & $\begin{array}{l}\text { State well } \\
\text { number }\end{array}$ & County & $\begin{array}{l}\text { Well depth } \\
\text { (ft bls) }\end{array}$ & $\begin{array}{l}\text { Depth to } \\
\text { top of open } \\
\text { interval } \\
\text { (ft bls) }\end{array}$ & $\begin{array}{c}\text { Depth to } \\
\text { bottom of } \\
\text { open interval } \\
\text { (ft bls) }\end{array}$ & $\begin{array}{c}\text { Date of } \\
\text { construction }\end{array}$ & $\begin{array}{l}\text { Aquifer } \\
\text { code }\end{array}$ & $\begin{array}{l}\text { Lithology } \\
\text { code }\end{array}$ \\
\hline 294731095414201 & LJ-65-11-514 & Harris & 1,336 & $\begin{array}{r}796 \\
902 \\
954 \\
996 \\
1,018 \\
1,066 \\
1,096 \\
1,140 \\
1,174 \\
1,214 \\
1,250 \\
1,276\end{array}$ & $\begin{array}{r}846 \\
920 \\
962 \\
1,006 \\
1,058 \\
1,088 \\
1,126 \\
1,148 \\
1,182 \\
1,244 \\
1,256 \\
1,316\end{array}$ & 2/10/1992 & 121EVGL & -- \\
\hline 295553095191201 & LJ-65-06-528 & Harris & 1,680 & 800 & 1,680 & $10 / 1 / 1982$ & 121EVGL & -- \\
\hline 293636095300401 & JY-65-28-309 & Fort Bend & 1,032 & $\begin{array}{l}770 \\
820 \\
930\end{array}$ & $\begin{array}{r}800 \\
840 \\
1,020\end{array}$ & $5 / 31 / 1969$ & 121EVGL & -- \\
\hline 293635095294101 & JY-65-29-107 & Fort Bend & 1,220 & $\begin{array}{r}750 \\
860 \\
950 \\
985 \\
1,025 \\
1,120 \\
1,150 \\
1,180\end{array}$ & $\begin{array}{r}790 \\
890 \\
965 \\
1,005 \\
1,105 \\
1,140 \\
1,170 \\
1,205\end{array}$ & $11 / 1 / 1979^{1}$ & 121EVGL & -- \\
\hline 293652095293601 & LJ-65-29-108 & Harris & 1,190 & $\begin{array}{r}750 \\
780 \\
850 \\
892 \\
940 \\
965 \\
1,024 \\
1,089 \\
1,129\end{array}$ & $\begin{array}{r}765 \\
820 \\
890 \\
930 \\
964 \\
1,000 \\
1,069 \\
1,109 \\
1,170\end{array}$ & $10 / 4 / 1982$ & 121EVGL & -- \\
\hline 294252095362101 & LJ-65-20-125 & Harris & 1,610 & $\begin{array}{l}704 \\
760 \\
790 \\
826 \\
854 \\
880 \\
958\end{array}$ & $\begin{array}{l}752 \\
784 \\
820 \\
842 \\
874 \\
902 \\
986\end{array}$ & $1 / 11 / 1983$ & $112 \mathrm{CEVG}$ & -- \\
\hline
\end{tabular}


Table 2. Well information for municipal supply wells sampled in the Houston, Texas, area, 2010—Continued.

\begin{tabular}{|c|c|c|c|c|c|c|c|c|}
\hline $\begin{array}{l}\text { U.S. Geological } \\
\text { Survey site number }\end{array}$ & $\begin{array}{l}\text { State well } \\
\text { number }\end{array}$ & County & $\begin{array}{l}\text { Well depth } \\
\text { (ft bls) }\end{array}$ & $\begin{array}{l}\text { Depth to } \\
\text { top of open } \\
\text { interval } \\
\text { (ft bls) }\end{array}$ & $\begin{array}{c}\text { Depth to } \\
\text { bottom of } \\
\text { open interval } \\
\text { (ft bls) }\end{array}$ & $\begin{array}{l}\text { Date of } \\
\text { construction }\end{array}$ & $\begin{array}{l}\text { Aquifer } \\
\text { code }\end{array}$ & $\begin{array}{l}\text { Lithology } \\
\text { code }\end{array}$ \\
\hline \multirow{11}{*}{$\begin{array}{l}294252095362101- \\
\text { Continued }\end{array}$} & & & & 1,010 & 1,046 & & & \\
\hline & & & & 1,054 & 1,072 & & & \\
\hline & & & & 1,092 & 1,110 & & & \\
\hline & & & & 1,134 & 1,170 & & & \\
\hline & & & & 1,190 & 1,210 & & & \\
\hline & & & & 1,218 & 1,240 & & & \\
\hline & & & & 1,246 & 1,276 & & & \\
\hline & & & & 1,330 & 1,370 & & & \\
\hline & & & & 1,414 & 1,442 & & & \\
\hline & & & & 1,492 & 1,512 & & & \\
\hline & & & & 1,560 & 1,590 & & & \\
\hline \multirow[t]{3}{*}{294127095342502} & LJ-65-20-519 & Harris & 1,450 & 1,146 & 1,164 & $7 / 12 / 1979$ & 121EVGL & -- \\
\hline & & & & 1,232 & 1,282 & & & \\
\hline & & & & 1,336 & 1,440 & & & \\
\hline 294047095345601 & LJ-65-20-516 & Harris & 960 & 710 & 960 & $11 / 1 / 1975^{1}$ & $112 \mathrm{CEVG}$ & CLSD \\
\hline \multirow[t]{8}{*}{294050095355501} & LJ-65-20-416 & Harris & 872 & 584 & 606 & -- & $112 \mathrm{CEVG}$ & -- \\
\hline & & & & 612 & 622 & & & \\
\hline & & & & 638 & 646 & & & \\
\hline & & & & 678 & 708 & & & \\
\hline & & & & 734 & 764 & & & \\
\hline & & & & 792 & 806 & & & \\
\hline & & & & 812 & 848 & & & \\
\hline & & & & 856 & 866 & & & \\
\hline
\end{tabular}

\footnotetext{
${ }^{1}$ Construction date was not reported, so the first day of the month was assigned arbitrarily.
} 
Table 3. Results of major ion, trace element, and radionuclide analyses from quality-control samples, equipment blanks, and field blanks collected in association with municipal supply wells sampled in the Houston, Texas, area, 2010.

[USGS TWSC, U.S. Geological Survey Texas Water Science Center; mg/L, milligrams per liter; $\mathrm{SiO}_{2}$, silicon dioxide; ${ }^{\circ} \mathrm{C}$, degrees Celsius; $\mu \mathrm{g} / \mathrm{L}$, micrograms per liter; Th, thorium; pCi/L, picocuries per liter; $\mathrm{CSU}$, combined standard uncertainty; $\mathrm{ssL}_{\mathrm{C}}$, sample-specific critical level; $\mathrm{Cs}$, cesium; <, less than; $\mathrm{E}$, estimated; $\mathrm{M}$, presence verified but not quantified; $\mathrm{R}$, radchem non-detect, below ssL $\mathrm{C}_{\mathrm{C}}$ ]

\begin{tabular}{|c|c|c|c|c|c|c|c|c|c|c|c|c|}
\hline $\begin{array}{l}\text { U.S. Geologi- } \\
\text { cal Survey site } \\
\text { number }\end{array}$ & $\begin{array}{c}\text { Site name or } \\
\text { State well number }\end{array}$ & Date & $\begin{array}{c}\text { Sample } \\
\text { start } \\
\text { time }\end{array}$ & $\begin{array}{l}\text { Sample } \\
\text { type }\end{array}$ & $\begin{array}{l}\text { Calcium, } \\
\text { water, } \\
\text { filtered } \\
\text { (mg/L) }\end{array}$ & $\begin{array}{l}\text { Magnesium, } \\
\text { water, } \\
\text { filtered } \\
\text { (mg/L) }\end{array}$ & $\begin{array}{l}\text { Potassium, } \\
\text { water, } \\
\text { filtered } \\
\text { (mg/L) }\end{array}$ & $\begin{array}{c}\text { Sodium, } \\
\text { water, } \\
\text { filtered } \\
\text { (mg/L) }\end{array}$ & $\begin{array}{c}\text { Bromide, } \\
\text { water, } \\
\text { filtered } \\
(\mathrm{mg} / \mathrm{L})\end{array}$ & $\begin{array}{l}\text { Chloride, } \\
\text { water, } \\
\text { filtered } \\
\text { (mg/L) }\end{array}$ & $\begin{array}{c}\text { Fluoride, } \\
\text { water, } \\
\text { filtered } \\
\text { (mg/L) }\end{array}$ & $\begin{array}{c}\text { Silica, } \\
\text { water, } \\
\text { filtered } \\
(\mathrm{mg} / \mathrm{L} \text { as } \\
\left.\mathrm{SiO}_{2}\right)\end{array}$ \\
\hline 301056095265000 & $\begin{array}{l}\text { USGS TWSC, Gulf Coast } \\
\text { Program Office Labora- } \\
\text { tory, Shenandoah, Tex. }\end{array}$ & $3 / 15 / 2010$ & 1359 & $\begin{array}{l}\text { Equipment } \\
\text { blank }\end{array}$ & 0.06 & $<0.016$ & $<0.06$ & $<0.10$ & $<0.02$ & $<0.12$ & $<0.08$ & $<0.06$ \\
\hline 294002095351001 & LJ-65-20-414 & $3 / 29 / 2010$ & 1059 & Field blank & E.02 & $<.016$ & E.06 & $<.10$ & $<.02$ & $<.12$ & $<.08$ & $<.06$ \\
\hline 294731095414201 & LJ-65-11-514 & $4 / 8 / 2010$ & 0959 & Field blank & E.03 & $<.016$ & $<.06$ & $<.10$ & $<.02$ & $<.12$ & $<.08$ & $<.06$ \\
\hline 301056095265000 & $\begin{array}{l}\text { USGS TWSC, Gulf Coast } \\
\text { Program Office Labora- } \\
\text { tory, Shenandoah, Tex. }\end{array}$ & $8 / 5 / 2010$ & 0859 & $\begin{array}{l}\text { Equipment } \\
\text { blank }\end{array}$ & E.03 & $<.016$ & $<.06$ & $<.10$ & $<.02$ & $<.12$ & $<.08$ & $<.06$ \\
\hline
\end{tabular}

\begin{tabular}{|c|c|c|c|c|c|c|c|c|c|c|c|c|}
\hline $\begin{array}{l}\text { U.S. Geologi- } \\
\text { cal Survey site } \\
\text { number }\end{array}$ & $\begin{array}{c}\text { Site name or } \\
\text { State well number }\end{array}$ & Date & $\begin{array}{c}\text { Sample } \\
\text { start } \\
\text { time }\end{array}$ & $\begin{array}{c}\text { Sample } \\
\text { type }\end{array}$ & $\begin{array}{c}\text { Sulfate, } \\
\text { water, } \\
\text { filtered } \\
\text { (mg/L) }\end{array}$ & $\begin{array}{c}\text { Residue on } \\
\text { evapora- } \\
\text { tion, dried } \\
\text { at } 180^{\circ} \mathrm{C} \text {, } \\
\text { water, } \\
\text { filtered } \\
\text { (mg/L) }\end{array}$ & $\begin{array}{c}\text { Arsenic, } \\
\text { water, } \\
\text { filtered } \\
(\mu \mathrm{g} / \mathrm{L})\end{array}$ & $\begin{array}{c}\text { Barium, } \\
\text { water, } \\
\text { filtered } \\
(\mu \mathrm{g} / \mathrm{L})\end{array}$ & $\begin{array}{c}\text { Boron, } \\
\text { water, } \\
\text { filtered } \\
(\mu \mathrm{g} / \mathrm{L})\end{array}$ & $\begin{array}{l}\text { Chromium, } \\
\text { water, } \\
\text { filtered } \\
(\mu \mathrm{g} / \mathrm{L})\end{array}$ & $\begin{array}{c}\text { Iron, } \\
\text { water, } \\
\text { filtered } \\
(\mu \mathrm{g} / \mathrm{L})\end{array}$ & $\begin{array}{c}\text { Lithium, } \\
\text { water, } \\
\text { filtered } \\
(\mu \mathrm{g} / \mathrm{L})\end{array}$ \\
\hline 301056095265000 & $\begin{array}{l}\text { USGS TWSC, Gulf } \\
\text { Coast Program } \\
\text { Office Laboratory, } \\
\text { Shenandoah, Tex. }\end{array}$ & $3 / 15 / 2010$ & 1359 & $\begin{array}{l}\text { Equipment } \\
\text { blank }\end{array}$ & $<0.18$ & $<10$ & $<0.04$ & M & $<3$ & $<0.12$ & $<6$ & $<0.4$ \\
\hline 294002095351001 & LJ-65-20-414 & $3 / 29 / 2010$ & 1059 & Field blank & $<.18$ & $<10$ & $<.04$ & M & $<3$ & $<.12$ & $<6$ & $<.4$ \\
\hline 294731095414201 & LJ-65-11-514 & $4 / 8 / 2010$ & 0959 & Field blank & $<.18$ & $<10$ & $<.04$ & M & $<3$ & $<.12$ & $<6$ & $<.4$ \\
\hline 301056095265000 & $\begin{array}{l}\text { USGS TWSC, Gulf } \\
\text { Coast Program } \\
\text { Office Laboratory, } \\
\text { Shenandoah, Tex. }\end{array}$ & $8 / 5 / 2010$ & 0859 & $\begin{array}{l}\text { Equipment } \\
\text { blank }\end{array}$ & $<.18$ & $<10$ & $<.04$ & $<0.14$ & $<3$ & $<.12$ & $<6$ & $<.4$ \\
\hline
\end{tabular}

Shenandoah, 
Table 3. Results of major ion, trace element, and radionuclide analyses from quality-control samples, equipment blanks, and field blanks collected in association with municipal supply wells sampled in the Houston, Texas, area, 2010_Continued.

\begin{tabular}{|c|c|c|c|c|c|c|c|c|c|c|c|c|}
\hline $\begin{array}{l}\text { U.S. Geologi- } \\
\text { cal Survey site } \\
\text { number }\end{array}$ & $\begin{array}{l}\text { Site name or } \\
\text { State well number }\end{array}$ & Date & $\begin{array}{c}\text { Sample } \\
\text { start } \\
\text { time }\end{array}$ & $\begin{array}{l}\text { Sample } \\
\text { type }\end{array}$ & $\begin{array}{c}\text { Man- } \\
\text { ganese, } \\
\text { water, } \\
\text { filtered } \\
\text { ( } \mu \mathrm{g} / \mathrm{L})\end{array}$ & $\begin{array}{c}\text { Molyb- } \\
\text { denum, } \\
\text { water, } \\
\text { filtered f } \\
\text { ( } \mu \mathrm{g} / \mathrm{L} \text { ) }\end{array}$ & 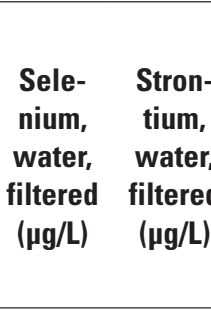 & $\begin{array}{c}\text { Vana- } \\
\text { dium, } \\
\text { water, } \\
\text { diltered } \\
(\mu \mathrm{g} / \mathrm{L})\end{array}$ & \multicolumn{2}{|c|}{$\begin{array}{c}\text { Alpha } \\
\text { radioactiv- } \\
\text { ity, 30-day } \\
\text { count, water, } \\
\text { filtered, } \\
\text { Th-230 curve } \\
\text { (pCi/L) }\end{array}$} & $\begin{array}{l}\text { Alpha } \\
\text { dioactivity, } \\
\text {-day count, } \\
\text { sigma CSU, } \\
\text { water, } \\
\text { filtered, } \\
\text { i-230 curve } \\
\text { (pCi/L) }\end{array}$ & $\begin{array}{c}\text { Alpha } \\
\text { radioactivity, } \\
\text { 30-day count, } \\
\text { ssL } \mathrm{c}_{\mathbf{c}^{\prime}} \text {, water, } \\
\text { filtered, } \\
\text { Th-230 curve } \\
\text { (pCi/L) }\end{array}$ \\
\hline 301056095265000 & $\begin{array}{l}\text { USGS TWSC, Gulf Coast Program } \\
\text { Office Laboratory, Shenandoah, Tex. }\end{array}$ & $3 / 15 / 2010$ & 1359 & $\begin{array}{l}\text { Equipment } \\
\text { blank }\end{array}$ & 2.4 & $<0.028$ & $<0.04$ & $<0.16$ & -0.04 & & 0.11 & 0.17 \\
\hline 294002095351001 & LJ-65-20-414 & $3 / 29 / 2010$ & 1059 & Field blank & 1.8 & $<.028$ & $<.04$ & $<.16$ & -- & & -- & -- \\
\hline 294731095414201 & LJ-65-11-514 & $4 / 8 / 2010$ & 0959 & Field blank & .6 & $<.028$ & $<.04$ & $<.16$ & -- & & -- & -- \\
\hline 301056095265000 & $\begin{array}{l}\text { USGS TWSC, Gulf Coast Program } \\
\text { Office Laboratory, Shenandoah, Tex. }\end{array}$ & $8 / 5 / 2010$ & 0859 & $\begin{array}{l}\text { Equipment } \\
\text { blank }\end{array}$ & 1.3 & $<.028$ & $<.04$ & $<.16$ & .10 & & .17 & .25 \\
\hline $\begin{array}{l}\text { U.S. Geological } \\
\text { Survey site number }\end{array}$ & $\begin{array}{c}\text { Site name or } \\
\text { State well number }\end{array}$ & Date & $\begin{array}{c}\text { Sample } \\
\text { start } \\
\text { time }\end{array}$ & $\begin{array}{l}\text { Sample } \\
\text { type }\end{array}$ & $\begin{array}{c}\text { Alpha } \\
\text { radio- } \\
\text { activity, } \\
\text { 30-day } \\
\text { count, } \\
\text { remark } \\
\text { code }\end{array}$ & $\begin{array}{c}\text { Alpha } \\
\text { radioac- } \\
\text { tivity, } \\
\text { 72-hour } \\
\text { count, } \\
\text { water, } \\
\text { filtered, } \\
\text { Th-230 } \\
\text { curve } \\
\text { (pCi/L) }\end{array}$ & $\begin{array}{c}\text { Alpha } \\
\text { radioactiv- } \\
\text { ity, 72-hour } \\
\text { count, } \\
\text { 1-sigma } \\
\text { CSU, } \\
\text { water, } \\
\text { filtered, } \\
\text { Th-230 } \\
\text { curve } \\
\text { (pCi/L) }\end{array}$ & $\begin{array}{c}\text { Alpha } \\
\text { radio- } \\
\text { activity, } \\
\text { 72-hour } \\
\text { count, } \\
\text { ssL }_{c^{\prime}} \\
\text { water, } \\
\text { filtered, } \\
\text { Th-230 } \\
\text { curve } \\
\text { (pCi/L) }\end{array}$ & $\begin{array}{l}\text { Alpha } \\
\text { radioac- } \\
\text { tivity, } \\
\text { 72-hour } \\
\text { count, } \\
\text { remark } \\
\text { code }\end{array}$ & $\begin{array}{c}\text { Beta } \\
\text { radio- } \\
\text { activity, } \\
\text { 30-day } \\
\text { count, } \\
\text { water, } \\
\text { filtered, } \\
\text { Cs-137 } \\
\text { curve } \\
\text { (pCi/L) }\end{array}$ & $\begin{array}{c}\text { Beta } \\
\text { radioac- } \\
\text { tivity, 30- } \\
\text { day count } \\
\text { 1-sigma } \\
\text { CSU, } \\
\text { water, } \\
\text { filtered, } \\
\text { Cs-137 } \\
\text { curve } \\
\text { (pCi/L) }\end{array}$ & $\begin{array}{cc} & \text { Beta } \\
\text { radioactiv- } & \text { ity, } \\
\text { tt, } & 30 \text {-day } \\
\text { count, } \\
\text { ssL }_{c^{\prime}} \\
\text { water, } \\
\text { filtered, } \\
\text { Cs-137 } \\
\text { curve } \\
\text { (pCi/L) }\end{array}$ \\
\hline 301056095265000 & $\begin{array}{l}\text { USGS TWSC, Gulf Coast Program } \\
\text { Office Laboratory, Shenandoah, Tex. }\end{array}$ & $3 / 15 / 2010$ & 1359 & $\begin{array}{c}\text { Equipment } \\
\text { blank }\end{array}$ & $\mathrm{R}$ & -0.070 & 0.085 & 0.15 & $\mathrm{R}$ & 0.06 & 0.34 & 0.55 \\
\hline 294002095351001 & LJ-65-20-414 & $3 / 29 / 2010$ & 1059 & $\begin{array}{l}\text { Field } \\
\text { blank }\end{array}$ & -- & -- & -- & -- & -- & -- & -- & -- \\
\hline 294731095414201 & LJ-65-11-514 & $4 / 8 / 2010$ & 0959 & $\begin{array}{l}\text { Field } \\
\text { blank }\end{array}$ & -- & -- & -- & -- & -- & -- & -- & -- \\
\hline 301056095265000 & $\begin{array}{l}\text { USGS TWSC, Gulf Coast Program } \\
\text { Office Laboratory, Shenandoah, Tex. }\end{array}$ & $8 / 5 / 2010$ & 0859 & $\begin{array}{l}\text { Equipment } \\
\text { blank }\end{array}$ & $\mathrm{R}$ & -.19 & .12 & .23 & $\mathrm{R}$ & -.13 & .36 & .6 \\
\hline
\end{tabular}


Table 3. Results of major ion, trace element, and radionuclide analyses from quality-control samples, equipment blanks, and field blanks collected in association with municipal supply wells sampled in the Houston, Texas, area, 2010-Continued.

\begin{tabular}{|c|c|c|c|c|c|c|c|c|c|c|c|c|}
\hline $\begin{array}{l}\text { U.S. Geological } \\
\text { Survey site number }\end{array}$ & $\begin{array}{c}\text { Site name or } \\
\text { State well number }\end{array}$ & Date & $\begin{array}{c}\text { Sample } \\
\text { start } \\
\text { time }\end{array}$ & $\begin{array}{l}\text { Sample } \\
\text { type }\end{array}$ & $\begin{array}{c}\text { Beta } \\
\text { radio- } \\
\text { activity, } \\
30 \text {-day } \\
\text { count, } \\
\text { remark } \\
\text { code }\end{array}$ & $\begin{array}{c}\text { Beta radio- } \\
\text { activity, } 72- \\
\text { hour count, } \\
\text { water, } \\
\text { filtered, Cs- } \\
137 \text { curve } \\
\text { (pCi/L) }\end{array}$ & $\begin{array}{c}\text { Beta radio- } \\
\text { activity, 72- } \\
\text { hour count, } \\
\text { 1-sigma } \\
\text { CSU, water, } \\
\text { filtered, } \\
\text { Cs-137 curve } \\
\text { (pCi/L) }\end{array}$ & $\begin{array}{l}\text { Beta radio- } \\
\text { activity, 72- } \\
\text { hour count, } \\
\text { ssL }_{c^{\prime}} \text { water, } \\
\text { filtered, } \\
\text { Cs-137 curve } \\
\text { (pCi/L) }\end{array}$ & $\begin{array}{l}\text { Beta } \\
\text { radioactiv- } \\
\text { ity, 72-hour } \\
\text { count, } \\
\text { remark } \\
\text { code }\end{array}$ & $\begin{array}{c}\text { Ura- } \\
\text { nium } \\
\text { (natu- } \\
\text { ral), } \\
\text { water, } \\
\text { filtered } \\
\text { ( } \mathrm{gg} / \mathrm{L} \text { ) }\end{array}$ & $\begin{array}{c}\text { Uranium } \\
\text { (natu- } \\
\text { ral), } \\
\text { LRL, } \\
\text { water, } \\
\text { filtered } \\
\text { ( } \mu \mathrm{g} / \mathrm{L})\end{array}$ & $\begin{array}{l}\text { Ura- } \\
\text { nium } \\
\text { (natu- } \\
\text { ral) } \\
\text { remark } \\
\text { code }\end{array}$ \\
\hline 301056095265000 & $\begin{array}{l}\text { USGS TWSC, Gulf Coast Program } \\
\text { Office Laboratory, Shenandoah, Tex. }\end{array}$ & $3 / 15 / 2010$ & 1359 & $\begin{array}{l}\text { Equipment } \\
\text { blank }\end{array}$ & $\mathrm{R}$ & 0.05 & 0.34 & 0.55 & $\mathrm{R}$ & 0.01 & 0.008 & $<$ \\
\hline 294002095351001 & LJ-65-20-414 & $3 / 29 / 2010$ & 1059 & Field blank & -- & -- & -- & -- & -- & .01 & .008 & $<$ \\
\hline 294731095414201 & LJ-65-11-514 & 4/8/2010 & 0959 & Field blank & -- & -- & -- & -- & -- & .01 & .008 & $<$ \\
\hline 301056095265000 & $\begin{array}{l}\text { USGS TWSC, Gulf Coast Program } \\
\text { Office Laboratory, Shenandoah, Tex. }\end{array}$ & $8 / 5 / 2010$ & 0859 & $\begin{array}{l}\text { Equipment } \\
\text { blank }\end{array}$ & $\mathrm{R}$ & -.27 & .39 & .64 & $\mathrm{R}$ & .01 & .008 & $<$ \\
\hline
\end{tabular}


Table 4. Physicochemical properties and results of major ions analyses in water samples collected from municipal supply wells in the Houston, Texas, area, 2010.

[nm, nanometers; NTRU, Nephelometric Turbidity Ratio Unit; mg/L, milligrams per liter; ${ }^{\circ} \mathrm{C}$, degrees Celsius; E, estimated; --, no data available; <, less than; CaCO ${ }_{3}$, calcium carbonate; $\mathrm{SiO}_{2}$, silicon dioxide; $\mathrm{U}$, analyzed for but not detected; M, presence verified but not quantified]

\begin{tabular}{|c|c|c|c|c|c|c|c|c|c|c|c|c|}
\hline $\begin{array}{l}\text { U.S. Geologi- } \\
\text { cal Survey site } \\
\text { number }\end{array}$ & $\begin{array}{l}\text { State well } \\
\text { number }\end{array}$ & Date & $\begin{array}{c}\text { Sample } \\
\text { start } \\
\text { time }\end{array}$ & Sample type & $\begin{array}{l}\text { Oxidation } \\
\text { reduction } \\
\text { potential } \\
\text { (ORP), } \\
\text { reference } \\
\text { electrode } \\
\text { not } \\
\text { specified } \\
\text { (millivolts) }\end{array}$ & $\begin{array}{l}\text { Turbidity, water, un- } \\
\text { filtered, broad band } \\
\text { light source }(400-680 \\
\text { nm), detectors at } \\
\text { multiple angles } \\
\text { including } 90 \\
30 \text { degrees, ratio- } \\
\text { metric correction } \\
\text { (NTRU) }\end{array}$ & $\begin{array}{c}\text { Barometric } \\
\text { pressure } \\
\text { (millime- } \\
\text { ters of } \\
\text { mercury) }\end{array}$ & $\begin{array}{l}\text { Dissolved } \\
\text { oxygen, } \\
\text { water, } \\
\text { unfiltered } \\
\text { (mg/L) }\end{array}$ & $\begin{array}{c}\text { pH, } \\
\text { water, } \\
\text { unfil- } \\
\text { tered, } \\
\text { field } \\
\text { (standard } \\
\text { units) }\end{array}$ & $\begin{array}{l}\text { Specific } \\
\text { conduc- } \\
\text { tance, } \\
\text { water, } \\
\text { unfiltered } \\
\text { (microsie- } \\
\text { mens per } \\
\text { centimeter } \\
\text { at } 25^{\circ} \mathrm{C} \text { ) }\end{array}$ & $\begin{array}{c}\text { Tem- } \\
\text { pera- } \\
\text { ture, } \\
\text { air } \\
\left({ }^{\circ} \mathrm{C}\right)\end{array}$ & $\begin{array}{c}\text { Tem- } \\
\text { pera- } \\
\text { ture, } \\
\text { water } \\
\left({ }^{\circ} \mathrm{C}\right)\end{array}$ \\
\hline 294921095312907 & LJ-65-12-633 & $3 / 16 / 2010$ & 1041 & Environmental & 123 & 0.6 & 765 & 3.5 & 7.2 & 562 & 18.0 & 22.9 \\
\hline 294900095312101 & LJ-65-12-619 & $3 / 16 / 2010$ & 1257 & Environmental & 24.0 & .9 & 765 & 1.2 & 7.4 & 516 & 15.5 & 24.5 \\
\hline 295027095312301 & LJ-65-12-328 & $3 / 17 / 2010$ & 0927 & Environmental & -131 & .2 & 764 & .9 & 7.7 & 649 & 14.5 & 24.1 \\
\hline 295027095312301 & $L J-65-12-328$ & $3 / 17 / 2010$ & 0928 & $\begin{array}{l}\text { Sequential } \\
\quad \text { replicate }\end{array}$ & -- & -- & -- & -- & -- & -- & -- & -- \\
\hline 294950095313701 & LJ-65-12-622 & $3 / 17 / 2010$ & 1114 & Environmental & -55.7 & .5 & 764 & 1.2 & 7.4 & 519 & 18.5 & 25.0 \\
\hline 294340095311103 & LJ-65-20-321 & $3 / 18 / 2010$ & 0952 & Environmental & 148 & .2 & 764 & .5 & 7.6 & 488 & 14.5 & 25.2 \\
\hline 294348095303702 & LJ-65-20-319 & $3 / 18 / 2010$ & 1147 & Environmental & 53.7 & .6 & 764 & .5 & 7.6 & 481 & 19.0 & 24.7 \\
\hline 294348095270401 & LJ-65-21-202 & $3 / 22 / 2010$ & 1002 & Environmental & -134 & .1 & 764 & $<.1$ & 7.8 & 575 & 14.0 & 28.2 \\
\hline 294338095270401 & LJ-65-21-201 & $3 / 22 / 2010$ & 1129 & Environmental & 4.7 & .1 & 764 & 1.3 & 7.2 & 531 & 17.0 & 23.9 \\
\hline 294333095275602 & LJ-65-21-143 & $3 / 22 / 2010$ & 1304 & Environmental & -9.6 & .1 & 763 & .1 & 7.6 & 504 & 20.5 & 25.6 \\
\hline 294329095284602 & LJ-65-21-148 & $3 / 23 / 2010$ & 1001 & Environmental & 165 & .1 & 761 & .7 & 7.5 & 521 & 19.8 & 25.2 \\
\hline 294329095284602 & $L J-65-21-148$ & $3 / 23 / 2010$ & 1002 & $\begin{array}{l}\text { Sequential } \\
\quad \text { replicate }\end{array}$ & -- & -- & -- & -- & -- & -- & -- & -- \\
\hline 294319095305901 & LJ-65-20-303 & $3 / 23 / 2010$ & 1123 & Environmental & 85.0 & .1 & 761 & 2.5 & 7.3 & 526 & 22.4 & 24.4 \\
\hline 294317095313001 & LJ-65-20-304 & $3 / 23 / 2010$ & 1252 & Environmental & -8.9 & .1 & 761 & .2 & 7.8 & 485 & -- & 25.9 \\
\hline
\end{tabular}




\begin{tabular}{|c|c|c|c|c|c|c|c|c|c|c|c|c|}
\hline $\begin{array}{l}\text { U.S. Geologi- } \\
\text { cal Survey site } \\
\text { number }\end{array}$ & $\begin{array}{l}\text { State well } \\
\text { number }\end{array}$ & Date & $\begin{array}{c}\text { Sample } \\
\text { start } \\
\text { time }\end{array}$ & Sample type & $\begin{array}{l}\text { Oxidation } \\
\text { reduction } \\
\text { potential } \\
\text { (ORP), } \\
\text { reference } \\
\text { electrode } \\
\text { not } \\
\text { specified } \\
\text { (millivolts) }\end{array}$ & $\begin{array}{l}\text { Turbidity, water, un- } \\
\text { filtered, broad band } \\
\text { light source }(400-680 \\
\text { nm), detectors at } \\
\text { multiple angles } \\
\text { including } 90 \\
30 \text { degrees, ratio- } \\
\text { metric correction } \\
\text { (NTRU) }\end{array}$ & $\begin{array}{c}\text { Barometric } \\
\text { pressure } \\
\text { (millime- } \\
\text { ters of } \\
\text { mercury) }\end{array}$ & $\begin{array}{c}\text { Dissolved } \\
\text { oxygen, } \\
\text { water, } \\
\text { unfiltered } \\
\text { (mg/L) }\end{array}$ & $\begin{array}{c}\text { pH, } \\
\text { water, } \\
\text { unfil- } \\
\text { tered, } \\
\text { field } \\
\text { (standard } \\
\text { units) }\end{array}$ & $\begin{array}{c}\text { Specific } \\
\text { conduc- } \\
\text { tance, } \\
\text { water, } \\
\text { unfiltered } \\
\text { (microsie- } \\
\text { mens per } \\
\text { centimeter } \\
\text { at } 25^{\circ} \mathrm{C} \text { ) }\end{array}$ & $\begin{array}{c}\text { Tem- } \\
\text { pera- } \\
\text { ture, } \\
\text { air } \\
\left({ }^{\circ} \mathrm{C}\right)\end{array}$ & $\begin{array}{c}\text { Tem- } \\
\text { pera- } \\
\text { ture, } \\
\text { water } \\
\left({ }^{\circ} \mathrm{C}\right)\end{array}$ \\
\hline 294328095290402 & LJ-65-21-149 & $3 / 24 / 2010$ & 1036 & Environmental & 40.7 & 1.1 & 759 & 0.4 & 7.5 & 497 & -- & 25.3 \\
\hline 294323095300103 & LJ-65-20-325 & $3 / 24 / 2010$ & 1151 & Environmental & -79.5 & .9 & 759 & .2 & 7.8 & 500 & -- & 25.3 \\
\hline 294201095355601 & LJ-65-20-405 & $3 / 24 / 2010$ & 1343 & Environmental & 25.3 & .1 & 757 & 2.9 & 7.3 & 528 & 19.0 & 24.4 \\
\hline 293732095300601 & LJ-65-20-911 & $3 / 25 / 2010$ & 0932 & Environmental & 96.5 & .1 & 760 & .4 & 7.4 & 531 & 21.7 & 25.4 \\
\hline 293734095293701 & LJ-65-21-708 & $3 / 25 / 2010$ & 1130 & Environmental & -38.7 & .1 & 761 & $<.1$ & 7.5 & 531 & 19.7 & 26.0 \\
\hline 293736095285301 & LJ-65-21-709 & $3 / 25 / 2010$ & 1257 & Environmental & -100 & .2 & 760 & $<.1$ & 7.5 & 518 & -- & 26.0 \\
\hline 294002095351001 & LJ-65-20-414 & $3 / 29 / 2010$ & 1108 & Environmental & 156 & .1 & 763 & .8 & 7.4 & 504 & 20.5 & 25.5 \\
\hline 294414095364202 & LJ-65-20-126 & $3 / 29 / 2010$ & 1313 & Environmental & -173 & .1 & 762 & $<.1$ & 7.6 & 487 & 25.5 & 26.5 \\
\hline 294456095341101 & LJ-65-12-820 & $3 / 30 / 2010$ & 0906 & Environmental & 124 & .3 & 761 & 2.6 & 7.4 & 498 & 18.3 & 24.7 \\
\hline 294501095343601 & LJ-65-12-817 & $3 / 30 / 2010$ & 1021 & Environmental & 466 & .5 & 762 & 3.5 & 7.4 & 501 & 23.1 & 24.2 \\
\hline 294519095383201 & LJ-65-11-918 & $3 / 30 / 2010$ & 1154 & Environmental & 178 & .2 & 761 & 4.2 & 7.4 & 487 & 27.0 & 24.1 \\
\hline 295246095351301 & LJ-65-04-723 & $3 / 31 / 2010$ & 0913 & Environmental & -11.3 & .7 & 759 & 1.1 & 7.4 & 473 & 24.0 & 25.3 \\
\hline 295249095364701 & LJ-65-04-728 & $3 / 31 / 2010$ & 1113 & Environmental & -163 & .4 & 759 & $<.1$ & 7.7 & 539 & 22.0 & 26.7 \\
\hline 295249095370701 & LJ-65-04-729 & $3 / 31 / 2010$ & 1228 & Environmental & -59.9 & 2.0 & 758 & 1.0 & 7.4 & 476 & 25.5 & 25.2 \\
\hline 295243095383101 & LJ-65-03-916 & $4 / 1 / 2010$ & 0941 & Environmental & -117 & .3 & 758 & .3 & 7.5 & 489 & 19.5 & 25.9 \\
\hline
\end{tabular}


Table 4. Physicochemical properties and results of major ions analyses in water samples collected from municipal supply wells in the Houston, Texas, area, 2010—Continued.

\begin{tabular}{|c|c|c|c|c|c|c|c|c|c|c|c|c|}
\hline $\begin{array}{l}\text { U.S. Geologi- } \\
\text { cal Survey site } \\
\text { number }\end{array}$ & $\begin{array}{c}\text { State well } \\
\text { number }\end{array}$ & Date & $\begin{array}{c}\text { Sample } \\
\text { start } \\
\text { time }\end{array}$ & Sample type & $\begin{array}{c}\text { Oxidation } \\
\text { reduction } \\
\text { potential } \\
\text { (ORP), } \\
\text { reference } \\
\text { electrode } \\
\quad \text { not } \\
\text { specified } \\
\text { (millivolts) }\end{array}$ & $\begin{array}{l}\text { Turbidity, water, un- } \\
\text { filtered, broad band } \\
\text { light source (400-680 } \\
\text { nm), detectors at } \\
\text { multiple angles } \\
\text { including 90 } \\
30 \text { degrees, ratio- } \\
\text { metric correction } \\
\text { (NTRU) }\end{array}$ & $\begin{array}{c}\text { Barometric } \\
\text { pressure } \\
\text { (millime- } \\
\text { ters of } \\
\text { mercury) }\end{array}$ & $\begin{array}{c}\text { Dissolved } \\
\text { oxygen, } \\
\text { water, } \\
\text { unfiltered } \\
(\mathrm{mg} / \mathrm{L})\end{array}$ & $\begin{array}{c}\text { pH, } \\
\text { water, } \\
\text { unfil- } \\
\text { tered, } \\
\text { field } \\
\text { (standard } \\
\text { units) }\end{array}$ & $\begin{array}{c}\text { Specific } \\
\text { conduc- } \\
\text { tance, } \\
\text { water, } \\
\text { unfiltered } \\
\text { (microsie- } \\
\text { mens per } \\
\text { centimeter } \\
\text { at } 25^{\circ} \mathrm{C} \text { ) }\end{array}$ & $\begin{array}{l}\text { Tem- } \\
\text { pera- } \\
\text { ture, } \\
\text { air } \\
\left({ }^{\circ} \mathrm{C}\right)\end{array}$ & $\begin{array}{l}\text { Tem- } \\
\text { pera- } \\
\text { ture, } \\
\text { water } \\
\left({ }^{\circ} \mathrm{C}\right)\end{array}$ \\
\hline 294717095401001 & LJ-65-11-804 & $4 / 1 / 2010$ & 1229 & Environmental & -135 & .4 & 758 & $<.1$ & 7.6 & 496 & 26.5 & 25.8 \\
\hline 294952095342601 & LJ-65-12-519 & $4 / 5 / 2010$ & 1030 & Environmental & -89.6 & .2 & 762 & $<.1$ & 7.5 & 484 & 24.5 & 24.8 \\
\hline 294952095342601 & $L J-65-12-519$ & $4 / 5 / 2010$ & 1031 & $\begin{array}{l}\text { Sequential } \\
\text { replicate }\end{array}$ & -- & -- & -- & -- & -- & -- & -- & -- \\
\hline 294925095341201 & LJ-65-12-520 & $4 / 5 / 2010$ & 1202 & Environmental & -149 & .2 & 762 & $<.1$ & 7.5 & 527 & 30.3 & 27.2 \\
\hline 294735095344001 & LJ-65-12-521 & $4 / 6 / 2010$ & 1042 & Environmental & -121 & .1 & 758 & $<.1$ & 7.6 & 502 & 26.0 & 27.5 \\
\hline 294627095375801 & LJ-65-11-914 & $4 / 6 / 2010$ & 1216 & Environmental & -79.6 & .2 & 758 & $<.1$ & 7.5 & 495 & 27.0 & 26.3 \\
\hline 294721095361001 & LJ-65-12-719 & $4 / 7 / 2010$ & 0909 & Environmental & 82.0 & 1.4 & 755 & 2.0 & 7.4 & 492 & 26.0 & 24.5 \\
\hline 294723095370501 & LJ-65-12-730 & $4 / 7 / 2010$ & 1040 & Environmental & -61.8 & .7 & 755 & $<.1$ & 7.5 & 485 & 24.5 & 25.9 \\
\hline 294723095382601 & LJ-65-11-920 & 4/7/2010 & 1209 & Environmental & -92.0 & .1 & 755 & $<.1$ & 7.5 & 493 & 28.0 & 26.5 \\
\hline 294731095414201 & LJ-65-11-514 & $4 / 8 / 2010$ & 1016 & Environmental & -105 & .1 & 762 & $<.1$ & 7.7 & 617 & 14.5 & 26.8 \\
\hline
\end{tabular}




\begin{tabular}{|c|c|c|c|c|c|c|c|c|c|c|c|c|}
\hline $\begin{array}{l}\text { U.S. Geologi- } \\
\text { cal Survey site } \\
\text { number }\end{array}$ & $\begin{array}{l}\text { State well } \\
\text { number }\end{array}$ & Date & $\begin{array}{c}\text { Sample } \\
\text { start } \\
\text { time }\end{array}$ & Sample type & $\begin{array}{l}\text { Oxidation } \\
\text { reduction } \\
\text { potential } \\
\text { (ORP), } \\
\text { reference } \\
\text { electrode } \\
\text { not } \\
\text { specified } \\
\text { (millivolts) }\end{array}$ & $\begin{array}{l}\text { Turbidity, water, un- } \\
\text { filtered, broad band } \\
\text { light source (400-680 } \\
\text { nm), detectors at } \\
\text { multiple angles } \\
\text { including } 90 \\
30 \text { degrees, ratio- } \\
\text { metric correction } \\
\text { (NTRU) }\end{array}$ & $\begin{array}{c}\text { Barometric } \\
\text { pressure } \\
\text { (millime- } \\
\text { ters of } \\
\text { mercury) }\end{array}$ & $\begin{array}{c}\text { Dissolved } \\
\text { oxygen, } \\
\text { water, } \\
\text { unfiltered } \\
\text { (mg/L) }\end{array}$ & $\begin{array}{c}\text { pH, } \\
\text { water, } \\
\text { unfil- } \\
\text { tered, } \\
\text { field } \\
\text { (standard } \\
\text { units) }\end{array}$ & $\begin{array}{c}\text { Specific } \\
\text { conduc- } \\
\text { tance, } \\
\text { water, } \\
\text { unfiltered } \\
\text { (microsie- } \\
\text { mens per } \\
\text { centimeter } \\
\text { at } 25^{\circ} \mathrm{C} \text { ) }\end{array}$ & $\begin{array}{c}\text { Tem- } \\
\text { pera- } \\
\text { ture, } \\
\text { air } \\
\left({ }^{\circ} \mathrm{C}\right)\end{array}$ & $\begin{array}{c}\text { Tem- } \\
\text { pera- } \\
\text { ture, } \\
\text { water } \\
\left({ }^{\circ} \mathrm{C}\right)\end{array}$ \\
\hline 293636095300401 & JY-65-28-309 & $10 / 28 / 2010$ & 1011 & Environmental & -- & 0.2 & 768 & $<0.1$ & 7.3 & 521 & 25.0 & 25.8 \\
\hline 293635095294101 & JY-65-29-107 & $10 / 28 / 2010$ & 1225 & Environmental & -- & .2 & 768 & $<.1$ & 7.3 & 724 & 29.5 & 26.1 \\
\hline 293652095293601 & LJ-65-29-108 & $10 / 28 / 2010$ & 1350 & Environmental & -- & .2 & 767 & $<.1$ & 7.3 & 596 & 27.0 & 25.8 \\
\hline 294252095362101 & LJ-65-20-125 & $11 / 3 / 2010$ & 1033 & Environmental & -- & .3 & 759 & 3.4 & 7.4 & 501 & 14.0 & 24.7 \\
\hline 294127095342502 & LJ-65-20-519 & $11 / 4 / 2010$ & 0945 & Environmental & -- & .3 & 764 & $<.1$ & 7.8 & 509 & 16.0 & 27.2 \\
\hline 294127095342502 & $L J-65-20-519$ & $11 / 4 / 2010$ & 0946 & $\begin{array}{l}\text { Sequential } \\
\quad \text { replicate }\end{array}$ & -- & -- & -- & -- & -- & -- & -- & -- \\
\hline 294047095345601 & LJ-65-20-516 & $11 / 4 / 2010$ & 1114 & Environmental & -- & .2 & 763 & 2.1 & 7.3 & 516 & 18.0 & 25.1 \\
\hline 294050095355501 & LJ-65-20-416 & $11 / 9 / 2010$ & 1159 & Environmental & -- & .3 & 758 & 4.4 & 7.3 & 568 & 26.0 & 24.1 \\
\hline
\end{tabular}


Table 4. Physicochemical properties and results of major ions analyses in water samples collected from municipal supply wells in the Houston, Texas, area, 2010—Continued.

\begin{tabular}{|c|c|c|c|c|c|c|c|c|c|c|c|c|}
\hline $\begin{array}{l}\text { U.S. Geologi- } \\
\text { cal Survey site } \\
\text { number }\end{array}$ & $\begin{array}{c}\text { State well } \\
\text { number }\end{array}$ & Date & $\begin{array}{c}\text { Sample } \\
\text { start } \\
\text { time }\end{array}$ & Sample type & $\begin{array}{c}\text { Calcium, } \\
\text { water, } \\
\text { filtered } \\
(\mathrm{mg} / \mathrm{L})\end{array}$ & $\begin{array}{c}\text { Magne- } \\
\text { sium, } \\
\text { water, } \\
\text { filtered } \\
(\mathrm{mg} / \mathrm{L})\end{array}$ & $\begin{array}{l}\text { Potassium, } \\
\text { water, } \\
\text { filtered } \\
\text { (mg/L) }\end{array}$ & $\begin{array}{c}\text { Sodium, } \\
\text { water, } \\
\text { filtered } \\
(\mathrm{mg} / \mathrm{L})\end{array}$ & $\begin{array}{c}\text { Alkalinity, } \\
\text { water, filtered, } \\
\text { inflection-point } \\
\text { titration method } \\
\text { (incremental } \\
\text { titration } \\
\text { method), field } \\
\text { (mg/L as } \mathrm{CaCO}_{3} \text { ) }\end{array}$ & $\begin{array}{l}\text { Bicarbonate, } \\
\text { water, filtered, } \\
\text { inflection- } \\
\text { point titration } \\
\text { method (incre- } \\
\text { mental titration } \\
\text { method), field } \\
(\mathrm{mg} / \mathrm{L})\end{array}$ & $\begin{array}{c}\text { Bro- } \\
\text { mide, } \\
\text { water, } \\
\text { filtered } \\
(\mathrm{mg} / \mathrm{L})\end{array}$ & $\begin{array}{c}\text { Chloride, } \\
\text { water, } \\
\text { filtered } \\
(\mathrm{mg} / \mathrm{L})\end{array}$ \\
\hline 294921095312907 & LJ-65-12-633 & $3 / 16 / 2010$ & 1041 & Environmental & 64.8 & 8.64 & 1.72 & 31.1 & 210 & 255 & 0.15 & 49.2 \\
\hline 294900095312101 & LJ-65-12-619 & $3 / 16 / 2010$ & 1257 & Environmental & 43.3 & 12.0 & 2.30 & 39.1 & 169 & 206 & .17 & 47.0 \\
\hline 295027095312301 & LJ-65-12-328 & $3 / 17 / 2010$ & 0927 & Environmental & 18.6 & 5.10 & 2.48 & 108 & 235 & 285 & .22 & 54.5 \\
\hline 295027095312301 & $L J-65-12-328$ & $3 / 17 / 2010$ & 0928 & $\begin{array}{l}\text { Sequential } \\
\quad \text { replicate }\end{array}$ & 17.7 & 5.15 & 2.52 & 113 & -- & -- & .22 & 55.3 \\
\hline 294950095313701 & LJ-65-12-622 & $3 / 17 / 2010$ & 1114 & Environmental & 46.5 & 11.2 & 2.30 & 36.7 & 169 & 206 & .18 & 47.3 \\
\hline 294340095311103 & LJ-65-20-321 & $3 / 18 / 2010$ & 0952 & Environmental & 22.9 & 4.97 & 1.67 & 68.8 & 230 & 279 & .13 & 31.1 \\
\hline 294348095303702 & LJ-65-20-319 & $3 / 18 / 2010$ & 1147 & Environmental & 28.8 & 5.85 & 1.74 & 59.4 & 179 & 218 & .13 & 31.5 \\
\hline 294348095270401 & LJ-65-21-202 & $3 / 22 / 2010$ & 1002 & Environmental & 14.4 & 3.73 & 1.85 & 110 & 276 & 333 & .14 & 38.8 \\
\hline 294338095270401 & LJ-65-21-201 & $3 / 22 / 2010$ & 1129 & Environmental & 48.4 & 12.3 & 2.31 & 41.3 & 190 & 230 & .14 & 42.9 \\
\hline 294333095275602 & LJ-65-21-143 & $3 / 22 / 2010$ & 1304 & Environmental & 24.3 & 5.76 & 1.90 & 72.3 & 190 & 230 & .12 & 33.5 \\
\hline 294329095284602 & LJ-65-21-148 & $3 / 23 / 2010$ & 1001 & Environmental & 33.8 & 7.03 & 1.97 & 64.4 & 190 & 230 & .13 & 37.7 \\
\hline 294329095284602 & $L J-65-21-148$ & $3 / 23 / 2010$ & 1002 & $\begin{array}{l}\text { Sequential } \\
\text { replicate }\end{array}$ & 33.3 & 6.89 & 1.97 & 60.3 & 190 & 230 & .13 & 37.7 \\
\hline 294319095305901 & LJ-65-20-303 & $3 / 23 / 2010$ & 1123 & Environmental & 52.2 & 8.66 & 1.88 & 40.3 & 190 & 230 & .14 & 41.4 \\
\hline 294317095313001 & LJ-65-20-304 & $3 / 23 / 2010$ & 1252 & Environmental & 20.2 & 4.22 & 1.59 & 75.4 & 179 & 217 & .10 & 29.0 \\
\hline 294328095290402 & LJ-65-21-149 & $3 / 24 / 2010$ & 1036 & Environmental & 34.7 & 7.06 & 1.93 & 56.9 & 169 & 206 & .12 & 35.0 \\
\hline 294323095300103 & LJ-65-20-325 & $3 / 24 / 2010$ & 1151 & Environmental & 20.3 & 4.41 & 1.58 & 80.7 & 184 & 223 & .11 & 30.8 \\
\hline
\end{tabular}




\begin{tabular}{|c|c|c|c|c|c|c|c|c|c|c|c|c|}
\hline $\begin{array}{l}\text { U.S. Geologi- } \\
\text { cal Survey site } \\
\text { number }\end{array}$ & $\begin{array}{l}\text { State well } \\
\text { number }\end{array}$ & Date & $\begin{array}{c}\text { Sample } \\
\text { start } \\
\text { time }\end{array}$ & Sample type & $\begin{array}{l}\text { Calcium, } \\
\text { water, } \\
\text { filtered } \\
\text { (mg/L) }\end{array}$ & $\begin{array}{c}\text { Magne- } \\
\text { sium, } \\
\text { water, } \\
\text { filtered } \\
\text { (mg/L) }\end{array}$ & $\begin{array}{l}\text { Potassium, } \\
\text { water, } \\
\text { filtered } \\
\text { (mg/L) }\end{array}$ & $\begin{array}{c}\text { Sodium, } \\
\text { water, } \\
\text { filtered } \\
\text { (mg/L) }\end{array}$ & $\begin{array}{c}\text { Alkalinity, } \\
\text { water, filtered, } \\
\text { inflection-point } \\
\text { titration method } \\
\text { (incremental } \\
\text { titration } \\
\text { method), field } \\
\text { (mg/L as } \mathrm{CaCO}_{3} \text { ) }\end{array}$ & $\begin{array}{c}\text { Bicarbonate, } \\
\text { water, filtered, } \\
\text { inflection- } \\
\text { point titration } \\
\text { method (incre- } \\
\text { mental titration } \\
\text { method), field } \\
(\mathrm{mg} / \mathrm{L}) \\
\end{array}$ & $\begin{array}{c}\text { Bro- } \\
\text { mide, } \\
\text { water, } \\
\text { filtered } \\
\text { (mg/L) }\end{array}$ & $\begin{array}{c}\text { Chloride, } \\
\text { water, } \\
\text { filtered } \\
\text { (mg/L) }\end{array}$ \\
\hline 294201095355601 & LJ-65-20-405 & $3 / 24 / 2010$ & 1343 & Environmental & 60.1 & 10.6 & 1.89 & 33.4 & 174 & 212 & 0.15 & 47.1 \\
\hline 293732095300601 & LJ-65-20-911 & $3 / 25 / 2010$ & 0932 & Environmental & 43.2 & 7.51 & 2.04 & 53.8 & 200 & 243 & .12 & 35.8 \\
\hline 293734095293701 & LJ-65-21-708 & $3 / 25 / 2010$ & 1130 & Environmental & 33.0 & 5.74 & 1.85 & 68.0 & 200 & 243 & .12 & 34.3 \\
\hline 293736095285301 & LJ-65-21-709 & $3 / 25 / 2010$ & 1257 & Environmental & 38.3 & 6.31 & 1.90 & 58.6 & 195 & 236 & .11 & 32.5 \\
\hline 294002095351001 & LJ-65-20-414 & $3 / 29 / 2010$ & 1108 & Environmental & 46.8 & 8.20 & 2.03 & 34.7 & 240 & 292 & .14 & 39.0 \\
\hline 294414095364202 & LJ-65-20-126 & $3 / 29 / 2010$ & 1313 & Environmental & 36.0 & 7.95 & 2.42 & 47.9 & 174 & 212 & .14 & 37.7 \\
\hline 294456095341101 & LJ-65-12-820 & $3 / 30 / 2010$ & 0906 & Environmental & 44.4 & 8.27 & 2.00 & 41.6 & 200 & 243 & .13 & 38.9 \\
\hline 294501095343601 & LJ-65-12-817 & $3 / 30 / 2010$ & 1021 & Environmental & 48.5 & 8.23 & 1.82 & 38.3 & 174 & 212 & .10 & 41.1 \\
\hline 294519095383201 & LJ-65-11-918 & $3 / 30 / 2010$ & 1154 & Environmental & 53.7 & 7.08 & 1.53 & 30.5 & 164 & 200 & .15 & 44.9 \\
\hline 295246095351301 & LJ-65-04-723 & $3 / 31 / 2010$ & 0913 & Environmental & 52.5 & 6.26 & 2.19 & 31.1 & 215 & 261 & .14 & 42.1 \\
\hline 295249095364701 & LJ-65-04-728 & $3 / 31 / 2010$ & 1113 & Environmental & 28.7 & 6.77 & 2.76 & 72.0 & 190 & 230 & .16 & 45.5 \\
\hline 295249095370701 & LJ-65-04-729 & $3 / 31 / 2010$ & 1228 & Environmental & 50.1 & 6.24 & 2.19 & 34.2 & 159 & 193 & .14 & 41.1 \\
\hline 295243095383101 & LJ-65-03-916 & $4 / 1 / 2010$ & 0941 & Environmental & 40.3 & 8.37 & 2.62 & 43.2 & 235 & 285 & .14 & 41.3 \\
\hline 294712095401301 & LJ-65-11-803 & $4 / 1 / 2010$ & 1124 & Environmental & 45.9 & 7.36 & 2.25 & 39.8 & 169 & 206 & .16 & 45.4 \\
\hline 294717095401001 & LJ-65-11-804 & $4 / 1 / 2010$ & 1229 & Environmental & 42.9 & 7.07 & 2.18 & 43.1 & 169 & 206 & .15 & 44.7 \\
\hline
\end{tabular}


Table 4. Physicochemical properties and results of major ions analyses in water samples collected from municipal supply wells in the Houston, Texas, area, 2010—Continued.

\begin{tabular}{|c|c|c|c|c|c|c|c|c|c|c|c|c|}
\hline $\begin{array}{l}\text { U.S. Geologi- } \\
\text { cal Survey site } \\
\text { number }\end{array}$ & $\begin{array}{c}\text { State well } \\
\text { number }\end{array}$ & Date & $\begin{array}{c}\text { Sample } \\
\text { start } \\
\text { time }\end{array}$ & Sample type & $\begin{array}{c}\text { Calcium, } \\
\text { water, } \\
\text { filtered } \\
(\mathrm{mg} / \mathrm{L})\end{array}$ & $\begin{array}{c}\text { Magne- } \\
\text { sium, } \\
\text { water, } \\
\text { filtered } \\
(\mathrm{mg} / \mathrm{L})\end{array}$ & $\begin{array}{c}\text { Potassium, } \\
\text { water, } \\
\text { filtered } \\
\text { (mg/L) }\end{array}$ & $\begin{array}{c}\text { Sodium, } \\
\text { water, } \\
\text { filtered } \\
(\mathrm{mg} / \mathrm{L})\end{array}$ & $\begin{array}{c}\text { Alkalinity, } \\
\text { water, filtered, } \\
\text { inflection-point } \\
\text { titration method } \\
\text { (incremental } \\
\text { titration } \\
\text { method), field } \\
\text { (mg/L as } \mathrm{CaCO}_{3} \text { ) }\end{array}$ & $\begin{array}{c}\text { Bicarbonate, } \\
\text { water, filtered, } \\
\text { inflection- } \\
\text { point titration } \\
\text { method (incre- } \\
\text { mental titration } \\
\text { method), field } \\
(\mathrm{mg} / \mathrm{L})\end{array}$ & $\begin{array}{c}\text { Bro- } \\
\text { mide, } \\
\text { water, } \\
\text { filtered } \\
(\mathrm{mg} / \mathrm{L})\end{array}$ & $\begin{array}{c}\text { Chloride, } \\
\text { water, } \\
\text { filtered } \\
\text { (mg/L) }\end{array}$ \\
\hline 294952095342601 & LJ-65-12-519 & $4 / 5 / 2010$ & 1030 & Environmental & 38.3 & 11.4 & 2.45 & 41.5 & 169 & 206 & 0.13 & 36.3 \\
\hline 294952095342601 & LJ-65-12-519 & $4 / 5 / 2010$ & 1031 & $\begin{array}{l}\text { Sequential } \\
\text { replicate }\end{array}$ & 37.4 & 11.1 & 2.37 & 40.0 & 179 & 218 & .13 & 36.4 \\
\hline 294925095341201 & LJ-65-12-520 & $4 / 5 / 2010$ & 1202 & Environmental & 35.3 & 7.16 & 2.44 & 56.5 & 190 & 230 & .16 & 43.4 \\
\hline 294844095342401 & LJ-65-12-522 & $4 / 5 / 2010$ & 1338 & Environmental & 36.8 & 8.03 & 2.54 & 49.6 & 184 & 224 & .16 & 42.5 \\
\hline 294800095344101 & LJ-65-12-516 & 4/6/2010 & 0920 & Environmental & 35.3 & 8.81 & 2.25 & 43.4 & 174 & 212 & .12 & 31.2 \\
\hline 294735095344001 & LJ-65-12-521 & 4/6/2010 & 1042 & Environmental & 33.5 & 7.63 & 2.44 & 54.0 & 184 & 224 & .14 & 38.2 \\
\hline 294627095375801 & LJ-65-11-914 & 4/6/2010 & 1216 & Environmental & 41.0 & 7.28 & 2.17 & 49.0 & 169 & 206 & .15 & 42.7 \\
\hline 294721095361001 & LJ-65-12-719 & 4/7/2010 & 0909 & Environmental & 42.2 & 11.9 & 2.26 & 37.1 & 182 & 221 & .11 & 35.9 \\
\hline 294723095370501 & LJ-65-12-730 & 4/7/2010 & 1040 & Environmental & 44.5 & 7.92 & 2.22 & 42.1 & 169 & 206 & .14 & 38.7 \\
\hline 294723095382601 & LJ-65-11-920 & 4/7/2010 & 1209 & Environmental & 39.5 & 7.34 & 2.30 & 44.8 & 174 & 212 & .15 & 40.9 \\
\hline 294731095414201 & LJ-65-11-514 & $4 / 8 / 2010$ & 1016 & Environmental & 25.6 & 4.40 & 1.89 & 93.3 & 225 & 273 & .16 & 49.8 \\
\hline 295553095191201 & LJ-65-06-528 & $4 / 8 / 2010$ & 1331 & Environmental & 35.0 & 6.29 & 1.97 & 40.9 & 164 & 200 & .12 & 33.9 \\
\hline 295027095312301 & LJ-65-12-328 & $5 / 6 / 2010$ & 0940 & Environmental & 19.2 & 4.99 & 2.23 & 113 & 250 & 303 & .21 & 53.6 \\
\hline 293636095300401 & JY-65-28-309 & $10 / 28 / 2010$ & 1011 & Environmental & 50.3 & 7.93 & 2.14 & 46.9 & 225 & 274 & .10 & 33.5 \\
\hline 293635095294101 & JY-65-29-107 & $10 / 28 / 2010$ & 1225 & Environmental & 49.2 & 8.02 & 2.22 & 86.0 & 210 & 255 & .16 & 80.8 \\
\hline 293652095293601 & LJ-65-29-108 & $10 / 28 / 2010$ & 1350 & Environmental & 51.3 & 8.73 & 2.16 & 61.7 & 195 & 237 & .13 & 51.1 \\
\hline
\end{tabular}




\begin{tabular}{|c|c|c|c|c|c|c|c|c|c|c|c|c|}
\hline $\begin{array}{l}\text { U.S. Geologi- } \\
\text { cal Survey site } \\
\text { number }\end{array}$ & $\begin{array}{l}\text { State well } \\
\text { number }\end{array}$ & Date & $\begin{array}{c}\text { Sample } \\
\text { start } \\
\text { time }\end{array}$ & Sample type & $\begin{array}{c}\text { Calcium, } \\
\text { water, } \\
\text { filtered } \\
\text { (mg/L) }\end{array}$ & $\begin{array}{c}\text { Magne- } \\
\text { sium, } \\
\text { water, } \\
\text { filtered } \\
\text { (mg/L) }\end{array}$ & $\begin{array}{c}\text { Potassium, } \\
\text { water, } \\
\text { filtered } \\
\text { (mg/L) }\end{array}$ & $\begin{array}{c}\text { Sodium, } \\
\text { water, } \\
\text { filtered } \\
(\mathrm{mg} / \mathrm{L})\end{array}$ & $\begin{array}{c}\text { Alkalinity, } \\
\text { water, filtered, } \\
\text { inflection-point } \\
\text { titration method } \\
\text { (incremental } \\
\text { titration } \\
\text { method), field } \\
\text { (mg/L as } \mathrm{CaCO}_{3} \text { ) }\end{array}$ & $\begin{array}{c}\text { Bicarbonate, } \\
\text { water, filtered, } \\
\text { inflection- } \\
\text { point titration } \\
\text { method (incre- } \\
\text { mental titration } \\
\text { method), field } \\
(\mathrm{mg} / \mathrm{L})\end{array}$ & $\begin{array}{c}\text { Bro- } \\
\text { mide, } \\
\text { water, } \\
\text { filtered } \\
\text { (mg/L) }\end{array}$ & $\begin{array}{c}\text { Chloride, } \\
\text { water, } \\
\text { filtered } \\
\text { (mg/L) }\end{array}$ \\
\hline 294252095362101 & LJ-65-20-125 & $11 / 3 / 2010$ & 1033 & Environmental & 54.3 & 8.71 & 1.86 & 33.2 & 230 & 280 & 0.16 & 45.3 \\
\hline 294127095342502 & LJ-65-20-519 & $11 / 4 / 2010$ & 0945 & Environmental & 20.1 & 5.22 & 1.82 & 77.5 & 169 & 205 & .13 & 35.8 \\
\hline 294127095342502 & $L J-65-20-519$ & $11 / 4 / 2010$ & 0946 & $\begin{array}{l}\text { Sequential } \\
\quad \text { replicate }\end{array}$ & 19.8 & 5.11 & 1.81 & 78.8 & 174 & 211 & .12 & 36.0 \\
\hline 294047095345601 & LJ-65-20-516 & $11 / 4 / 2010$ & 1114 & Environmental & 53.2 & 9.33 & 1.95 & 34.8 & 169 & 206 & .16 & 43.1 \\
\hline 294050095355501 & LJ-65-20-416 & $11 / 9 / 2010$ & 1159 & Environmental & 69.7 & 11.2 & 1.65 & 35.1 & 174 & 212 & .18 & 54.9 \\
\hline
\end{tabular}


Table 4. Physicochemical properties and results of major ions analyses in water samples collected from municipal supply wells in the Houston, Texas, area, 2010 —Continued.

\begin{tabular}{|c|c|c|c|c|c|c|c|c|c|c|}
\hline $\begin{array}{l}\text { U.S. Geological } \\
\text { Survey site number }\end{array}$ & $\begin{array}{l}\text { State well } \\
\text { number }\end{array}$ & Date & $\begin{array}{c}\text { Sample } \\
\text { start } \\
\text { time }\end{array}$ & Sample type & $\begin{array}{c}\text { Fluoride, } \\
\text { water, filtered } \\
\text { (mg/L) }\end{array}$ & $\begin{array}{l}\text { Silica, water, } \\
\text { filtered } \\
\left(\mathrm{mg} / \mathrm{L} \text { as } \mathrm{SiO}_{2}\right)\end{array}$ & $\begin{array}{l}\text { Sulfate, water, } \\
\text { filtered } \\
\text { (mg/L) }\end{array}$ & $\begin{array}{l}\text { Hydrogen } \\
\text { sulfide, water, } \\
\text { unfiltered } \\
(\mathrm{mg} / \mathrm{L})^{1}\end{array}$ & $\begin{array}{l}\text { Sulfide, water, } \\
\text { unfiltered, field } \\
(\mathrm{mg} / \mathrm{L})\end{array}$ & $\begin{array}{c}\text { Residue on } \\
\text { evaporation, } \\
\text { dried at } \\
180^{\circ} \mathrm{C} \text {, water, } \\
\text { filtered } \\
\text { (mg/L) }\end{array}$ \\
\hline 294921095312907 & LJ-65-12-633 & $3 / 16 / 2010$ & 1041 & Environmental & 0.19 & 30.2 & 6.41 & $\mathrm{U}$ & -- & 307 \\
\hline 294900095312101 & LJ-65-12-619 & $3 / 16 / 2010$ & 1257 & Environmental & .22 & 24.5 & 12.5 & $\mathrm{U}$ & 0.40 & 284 \\
\hline 295027095312301 & LJ-65-12-328 & $3 / 17 / 2010$ & 0927 & Environmental & .62 & 19.2 & 4.93 & M & .20 & 385 \\
\hline 295027095312301 & $L J-65-12-328$ & $3 / 17 / 2010$ & 0928 & $\begin{array}{l}\text { Sequential } \\
\text { replicate }\end{array}$ & .62 & 19.9 & 5.00 & -- & .30 & 413 \\
\hline 294950095313701 & LJ-65-12-622 & $3 / 17 / 2010$ & 1114 & Environmental & .22 & 24.5 & 13.0 & $\mathrm{U}$ & -- & 294 \\
\hline 294340095311103 & LJ-65-20-321 & $3 / 18 / 2010$ & 0952 & Environmental & .42 & 20.6 & 14.6 & $\mathrm{U}$ & $<.20$ & 284 \\
\hline 294348095303702 & LJ-65-20-319 & $3 / 18 / 2010$ & 1147 & Environmental & .37 & 22.2 & 14.8 & $\mathrm{U}$ & $<.20$ & 280 \\
\hline 294348095270401 & LJ-65-21-202 & $3 / 22 / 2010$ & 1002 & Environmental & .61 & 17.5 & 10.5 & M & $<.20$ & 340 \\
\hline 294338095270401 & LJ-65-21-201 & $3 / 22 / 2010$ & 1129 & Environmental & .23 & 25.7 & 12.3 & $\mathrm{U}$ & -- & 306 \\
\hline 294333095275602 & LJ-65-21-143 & $3 / 22 / 2010$ & 1304 & Environmental & .45 & 19.3 & 13.0 & $\mathrm{U}$ & $<.20$ & 292 \\
\hline 294329095284602 & LJ-65-21-148 & $3 / 23 / 2010$ & 1001 & Environmental & .39 & 22.6 & 12.3 & $\mathrm{U}$ & $<.20$ & 306 \\
\hline 294329095284602 & $L J-65-21-148$ & $3 / 23 / 2010$ & 1002 & $\begin{array}{l}\text { Sequential } \\
\quad \text { replicate }\end{array}$ & .39 & 22.4 & 12.3 & -- & $<.20$ & 293 \\
\hline 294319095305901 & LJ-65-20-303 & $3 / 23 / 2010$ & 1123 & Environmental & .26 & 28.5 & 9.86 & $\mathrm{U}$ & -- & 307 \\
\hline 294317095313001 & LJ-65-20-304 & $3 / 23 / 2010$ & 1252 & Environmental & .45 & 20.5 & 15.5 & $\mathrm{U}$ & -- & 282 \\
\hline
\end{tabular}




\begin{tabular}{|c|c|c|c|c|c|c|c|c|c|c|}
\hline $\begin{array}{l}\text { U.S. Geological } \\
\text { Survey site number }\end{array}$ & $\begin{array}{l}\text { State well } \\
\text { number }\end{array}$ & Date & $\begin{array}{c}\text { Sample } \\
\text { start } \\
\text { time }\end{array}$ & Sample type & $\begin{array}{c}\text { Fluoride, } \\
\text { water, filtered } \\
(\mathrm{mg} / \mathrm{L})\end{array}$ & $\begin{array}{l}\text { Silica, water, } \\
\text { filtered } \\
\text { (mg/L as } \mathrm{SiO}_{2} \text { ) }\end{array}$ & $\begin{array}{l}\text { Sulfate, water, } \\
\text { filtered } \\
\text { (mg/L) }\end{array}$ & $\begin{array}{c}\text { Hydrogen } \\
\text { sulfide, water, } \\
\text { unfiltered } \\
(\mathrm{mg} / \mathrm{L})^{1}\end{array}$ & $\begin{array}{c}\text { Sulfide, water, } \\
\text { unfiltered, field } \\
\text { (mg/L) }\end{array}$ & $\begin{array}{c}\text { Residue on } \\
\text { evaporation, } \\
\text { dried at } \\
180^{\circ} \mathrm{C} \text {, water, } \\
\text { filtered } \\
\text { (mg/L) }\end{array}$ \\
\hline 294328095290402 & LJ-65-21-149 & $3 / 24 / 2010$ & 1036 & Environmental & 0.37 & 23.6 & 14.0 & $\mathrm{U}$ & $<0.20$ & 287 \\
\hline 294323095300103 & LJ-65-20-325 & $3 / 24 / 2010$ & 1151 & Environmental & .56 & 19.0 & 14.9 & $\mathrm{U}$ & $<.20$ & 299 \\
\hline 294201095355601 & LJ-65-20-405 & $3 / 24 / 2010$ & 1343 & Environmental & .22 & 28.9 & 9.88 & $\mathrm{U}$ & -- & 307 \\
\hline 293732095300601 & LJ-65-20-911 & $3 / 25 / 2010$ & 0932 & Environmental & .43 & 26.7 & 13.4 & $\mathrm{U}$ & $<.20$ & 308 \\
\hline 293734095293701 & LJ-65-21-708 & $3 / 25 / 2010$ & 1130 & Environmental & .49 & 24.1 & 15.5 & $\mathrm{U}$ & $<.20$ & 314 \\
\hline 293736095285301 & LJ-65-21-709 & $3 / 25 / 2010$ & 1257 & Environmental & .46 & 25.1 & 14.7 & $\mathrm{U}$ & $<.20$ & 307 \\
\hline 294002095351001 & LJ-65-20-414 & $3 / 29 / 2010$ & 1108 & Environmental & .25 & 27.3 & 14.1 & $\mathrm{U}$ & $<.20$ & 287 \\
\hline 294414095364202 & LJ-65-20-126 & $3 / 29 / 2010$ & 1313 & Environmental & .27 & 21.1 & 14.9 & M & $<.20$ & 272 \\
\hline 294456095341101 & LJ-65-12-820 & $3 / 30 / 2010$ & 0906 & Environmental & .24 & 27.0 & 12.0 & $\mathrm{U}$ & -- & 296 \\
\hline 294501095343601 & LJ-65-12-817 & $3 / 30 / 2010$ & 1021 & Environmental & .22 & 29.3 & 10.3 & $\mathrm{U}$ & -- & 306 \\
\hline 294519095383201 & LJ-65-11-918 & $3 / 30 / 2010$ & 1154 & Environmental & .20 & 32.0 & 8.61 & $\mathrm{U}$ & -- & 290 \\
\hline 295246095351301 & LJ-65-04-723 & $3 / 31 / 2010$ & 0913 & Environmental & .19 & 24.5 & 12.6 & $\mathrm{U}$ & $<.20$ & 278 \\
\hline 295249095364701 & LJ-65-04-728 & $3 / 31 / 2010$ & 1113 & Environmental & .33 & 21.0 & 11.8 & M & $<.20$ & 312 \\
\hline 295249095370701 & LJ-65-04-729 & $3 / 31 / 2010$ & 1228 & Environmental & .20 & 24.1 & 13.1 & $\mathrm{U}$ & -- & 274 \\
\hline
\end{tabular}


Table 4. Physicochemical properties and results of major ions analyses in water samples collected from municipal supply wells in the Houston, Texas, area, 2010 —Continued.

\begin{tabular}{|c|c|c|c|c|c|c|c|c|c|c|}
\hline $\begin{array}{l}\text { U.S. Geological } \\
\text { Survey site number }\end{array}$ & $\begin{array}{l}\text { State well } \\
\text { number }\end{array}$ & Date & $\begin{array}{c}\text { Sample } \\
\text { start } \\
\text { time }\end{array}$ & Sample type & $\begin{array}{c}\text { Fluoride, } \\
\text { water, filtered } \\
\text { (mg/L) }\end{array}$ & $\begin{array}{l}\text { Silica, water, } \\
\text { filtered } \\
\left(\mathrm{mg} / \mathrm{L} \text { as } \mathrm{SiO}_{2}\right)\end{array}$ & $\begin{array}{l}\text { Sulfate, water, } \\
\text { filtered } \\
\text { (mg/L) }\end{array}$ & $\begin{array}{l}\text { Hydrogen } \\
\text { sulfide, water, } \\
\text { unfiltered } \\
(\mathrm{mg} / \mathrm{L})^{1}\end{array}$ & $\begin{array}{l}\text { Sulfide, water, } \\
\text { unfiltered, field } \\
\text { (mg/L) }\end{array}$ & $\begin{array}{c}\text { Residue on } \\
\text { evaporation, } \\
\text { dried at } \\
180^{\circ} \mathrm{C} \text {, water, } \\
\text { filtered } \\
\text { (mg/L) }\end{array}$ \\
\hline 295243095383101 & LJ-65-03-916 & $4 / 1 / 2010$ & 0941 & Environmental & 0.22 & 22.7 & 13.5 & M & $<0.20$ & 279 \\
\hline 294712095401301 & LJ-65-11-803 & $4 / 1 / 2010$ & 1124 & Environmental & .22 & 22.0 & 14.1 & M & $<.20$ & 289 \\
\hline 294717095401001 & LJ-65-11-804 & $4 / 1 / 2010$ & 1229 & Environmental & .22 & 21.9 & 14.6 & M & $<.20$ & 281 \\
\hline 294952095342601 & LJ-65-12-519 & $4 / 5 / 2010$ & 1030 & Environmental & .28 & 23.5 & 15.5 & $\mathrm{U}$ & $<.20$ & 272 \\
\hline 294952095342601 & $L J-65-12-519$ & $4 / 5 / 2010$ & 1031 & $\begin{array}{l}\text { Sequential } \\
\text { replicate }\end{array}$ & .31 & 22.8 & 15.2 & -- & $<.20$ & 273 \\
\hline 294925095341201 & LJ-65-12-520 & $4 / 5 / 2010$ & 1202 & Environmental & .32 & 19.1 & 12.2 & M & $<.20$ & 298 \\
\hline 294844095342401 & LJ-65-12-522 & $4 / 5 / 2010$ & 1338 & Environmental & .26 & 20.1 & 14.4 & $\mathrm{U}$ & $<.20$ & 294 \\
\hline 294800095344101 & LJ-65-12-516 & $4 / 6 / 2010$ & 0920 & Environmental & .28 & 23.5 & 16.8 & M & $<.20$ & 269 \\
\hline 294735095344001 & LJ-65-12-521 & $4 / 6 / 2010$ & 1042 & Environmental & .30 & 19.8 & 15.7 & $\mathrm{U}$ & $<.20$ & 289 \\
\hline 294627095375801 & LJ-65-11-914 & $4 / 6 / 2010$ & 1216 & Environmental & .25 & 20.3 & 14.5 & $\mathrm{U}$ & $<.20$ & 279 \\
\hline 294721095361001 & LJ-65-12-719 & $4 / 7 / 2010$ & 0909 & Environmental & .22 & 26.2 & 8.65 & $\mathrm{U}$ & -- & 282 \\
\hline 294723095370501 & LJ-65-12-730 & $4 / 7 / 2010$ & 1040 & Environmental & .23 & 21.0 & 13.3 & $\mathrm{U}$ & $<.20$ & 276 \\
\hline 294723095382601 & LJ-65-11-920 & $4 / 7 / 2010$ & 1209 & Environmental & .28 & 20.3 & 14.6 & $\mathrm{U}$ & $<.20$ & 277 \\
\hline 294731095414201 & LJ-65-11-514 & $4 / 8 / 2010$ & 1016 & Environmental & .51 & 18.8 & 12.3 & M & $<.20$ & 349 \\
\hline
\end{tabular}




\begin{tabular}{|c|c|c|c|c|c|c|c|c|c|c|}
\hline $\begin{array}{l}\text { U.S. Geological } \\
\text { Survey site number }\end{array}$ & $\begin{array}{l}\text { State well } \\
\text { number }\end{array}$ & Date & $\begin{array}{c}\text { Sample } \\
\text { start } \\
\text { time }\end{array}$ & Sample type & $\begin{array}{c}\text { Fluoride, } \\
\text { water, filtered } \\
\text { (mg/L) }\end{array}$ & $\begin{array}{l}\text { Silica, water, } \\
\text { filtered } \\
\left.\text { (mg/L as } \mathrm{SiO}_{2}\right)\end{array}$ & $\begin{array}{l}\text { Sulfate, water, } \\
\text { filtered } \\
\text { (mg/L) }\end{array}$ & $\begin{array}{c}\text { Hydrogen } \\
\text { sulfide, water, } \\
\text { unfiltered } \\
(\mathrm{mg} / \mathrm{L})^{1}\end{array}$ & $\begin{array}{c}\text { Sulfide, water, } \\
\text { unfiltered, field } \\
\text { (mg/L) }\end{array}$ & $\begin{array}{c}\text { Residue on } \\
\text { evaporation, } \\
\text { dried at } \\
180^{\circ} \mathrm{C} \text {, water, } \\
\text { filtered } \\
\text { (mg/L) }\end{array}$ \\
\hline 295553095191201 & LJ-65-06-528 & $4 / 8 / 2010$ & 1331 & Environmental & 0.22 & 19.5 & 6.40 & M & $<0.20$ & 225 \\
\hline 295027095312301 & LJ-65-12-328 & $5 / 6 / 2010$ & 0940 & Environmental & .63 & 18.0 & 5.03 & M & -- & 370 \\
\hline 293636095300401 & JY-65-28-309 & $10 / 28 / 2010$ & 1011 & Environmental & .38 & 22.2 & 14.9 & M & $<.20$ & 295 \\
\hline 293635095294101 & JY-65-29-107 & $10 / 28 / 2010$ & 1225 & Environmental & .44 & 22.6 & 17.1 & M & $<.20$ & 406 \\
\hline 293652095293601 & LJ-65-29-108 & $10 / 28 / 2010$ & 1350 & Environmental & .34 & 22.6 & 15.5 & M & $<.20$ & 330 \\
\hline 294252095362101 & LJ-65-20-125 & $11 / 3 / 2010$ & 1033 & Environmental & .21 & 28.4 & 10.3 & $\mathrm{U}$ & -- & 283 \\
\hline 294127095342502 & LJ-65-20-519 & $11 / 4 / 2010$ & 0945 & Environmental & .54 & 18.4 & 15.9 & M & $<.20$ & 299 \\
\hline 294127095342502 & $L J-65-20-519$ & $11 / 4 / 2010$ & 0946 & $\begin{array}{l}\text { Sequential } \\
\text { replicate }\end{array}$ & .55 & 16.6 & 15.9 & -- & $<.20$ & 294 \\
\hline 294047095345601 & LJ-65-20-516 & $11 / 4 / 2010$ & 1114 & Environmental & .24 & 30.7 & 12.1 & $\mathrm{U}$ & -- & 298 \\
\hline 294050095355501 & LJ-65-20-416 & $11 / 9 / 2010$ & 1159 & Environmental & .22 & 32.1 & 8.77 & $\mathrm{U}$ & -- & 334 \\
\hline
\end{tabular}


Table 5. Results of trace elements analyses of water samples collected from municipal supply wells in the Houston, Texas, area, 2010.

[ $\mu \mathrm{g} / \mathrm{L}$, micrograms per liter; <, less than; E, estimated; --, no data available]

\begin{tabular}{|c|c|c|c|c|c|c|c|c|c|c|}
\hline $\begin{array}{c}\text { U.S. Geologi- } \\
\text { cal Survey site } \\
\text { number }\end{array}$ & $\begin{array}{c}\text { State well } \\
\text { number }\end{array}$ & Date & $\begin{array}{c}\text { Sample } \\
\text { start time }\end{array}$ & Sample type & $\begin{array}{c}\text { Arsenic, } \\
\text { water, filtered } \\
(\mu \mathrm{g} / \mathrm{L})\end{array}$ & $\begin{array}{c}\text { Barium, } \\
\text { water, filtered } \\
(\mu \mathrm{g} / \mathrm{L})\end{array}$ & $\begin{array}{c}\text { Boron, water, } \\
\text { filtered } \\
(\mu \mathrm{g} / \mathrm{L})\end{array}$ & $\begin{array}{c}\text { Chromium, } \\
\text { water, filtered } \\
(\mu \mathrm{g} / \mathrm{L})\end{array}$ & $\begin{array}{l}\text { Iron, water, } \\
\text { filtered } \\
(\mu \mathrm{g} / \mathrm{L})\end{array}$ & $\begin{array}{c}\text { Lithium, water, } \\
\text { filtered } \\
(\mu \mathrm{g} / \mathrm{L})\end{array}$ \\
\hline 294921095312907 & LJ-65-12-633 & $3 / 16 / 2010$ & 1041 & Environmental & 1.9 & 302 & 48 & 1.5 & 10 & 12.7 \\
\hline 294900095312101 & LJ-65-12-619 & $3 / 16 / 2010$ & 1257 & Environmental & 2.4 & 220 & 50 & .27 & 10 & 18.4 \\
\hline 295027095312301 & LJ-65-12-328 & $3 / 17 / 2010$ & 0927 & Environmental & 23.5 & 320 & 182 & $<.12$ & 225 & 23.2 \\
\hline 295027095312301 & $L J-65-12-328$ & $3 / 17 / 2010$ & 0928 & $\begin{array}{l}\text { Sequential } \\
\text { replicate }\end{array}$ & 23.5 & 329 & 204 & $<.12$ & 222 & 26.1 \\
\hline 294950095313701 & LJ-65-12-622 & $3 / 17 / 2010$ & 1114 & Environmental & 1.9 & 214 & 46 & .31 & 31 & 19.1 \\
\hline 294340095311103 & LJ-65-20-321 & $3 / 18 / 2010$ & 0952 & Environmental & 4.7 & 185 & 94 & .77 & E4 & 18.6 \\
\hline 294348095303702 & LJ-65-20-319 & $3 / 18 / 2010$ & 1147 & Environmental & 4.2 & 196 & 96 & 1.0 & 7 & 21.4 \\
\hline 294348095270401 & LJ-65-21-202 & $3 / 22 / 2010$ & 1002 & Environmental & 4.9 & 236 & 173 & $<.12$ & 22 & 21.1 \\
\hline 294338095270401 & LJ-65-21-201 & $3 / 22 / 2010$ & 1129 & Environmental & 2.7 & 237 & 56 & 2.0 & $<6$ & 19.0 \\
\hline 294333095275602 & LJ-65-21-143 & $3 / 22 / 2010$ & 1304 & Environmental & 5.1 & 308 & 108 & .26 & $<6$ & 18.8 \\
\hline 294329095284602 & LJ-65-21-148 & $3 / 23 / 2010$ & 1001 & Environmental & 4.4 & 238 & 101 & .69 & 7 & 19.7 \\
\hline 294329095284602 & $L J-65-21-148$ & $3 / 23 / 2010$ & 1002 & $\begin{array}{l}\text { Sequential } \\
\text { replicate }\end{array}$ & 4.5 & 239 & 107 & 1.3 & E6 & 21.4 \\
\hline 294319095305901 & LJ-65-20-303 & $3 / 23 / 2010$ & 1123 & Environmental & 4.4 & 231 & 59 & 2.8 & $<6$ & 16.7 \\
\hline 294317095313001 & LJ-65-20-304 & $3 / 23 / 2010$ & 1252 & Environmental & 3.8 & 168 & 99 & $<.12$ & 11 & 19.8 \\
\hline 294328095290402 & LJ-65-21-149 & $3 / 24 / 2010$ & 1036 & Environmental & 4.1 & 237 & 84 & .79 & 13 & 17.3 \\
\hline 294323095300103 & LJ-65-20-325 & $3 / 24 / 2010$ & 1151 & Environmental & 3.9 & 191 & 122 & E.09 & 57 & 18.1 \\
\hline 294201095355601 & LJ-65-20-405 & $3 / 24 / 2010$ & 1343 & Environmental & 2.5 & 234 & 52 & 1.8 & $<6$ & 13.7 \\
\hline
\end{tabular}


Table 5. Results of trace elements analyses of water samples collected from municipal supply wells in the Houston, Texas, area, 2010-Continued.

\begin{tabular}{|c|c|c|c|c|c|c|c|c|c|c|}
\hline $\begin{array}{l}\text { U.S. Geologi- } \\
\text { cal Survey site } \\
\text { number }\end{array}$ & $\begin{array}{l}\text { State well } \\
\text { number }\end{array}$ & Date & $\begin{array}{l}\text { Sample } \\
\text { start time }\end{array}$ & Sample type & $\begin{array}{c}\text { Arsenic, } \\
\text { water, filtered } \\
(\mu \mathrm{g} / \mathrm{L})\end{array}$ & $\begin{array}{c}\text { Barium, } \\
\text { water, filtered } \\
(\mu \mathrm{g} / \mathrm{L})\end{array}$ & $\begin{array}{l}\text { Boron, water, } \\
\text { filtered } \\
(\mu \mathrm{g} / \mathrm{L})\end{array}$ & $\begin{array}{c}\text { Chromium, } \\
\text { water, filtered } \\
(\mu \mathrm{g} / \mathrm{L})\end{array}$ & $\begin{array}{l}\text { Iron, water, } \\
\text { filtered } \\
(\mu \mathrm{g} / \mathrm{L})\end{array}$ & $\begin{array}{l}\text { Lithium, water, } \\
\text { filtered } \\
(\mu \mathrm{g} / \mathrm{L})\end{array}$ \\
\hline 293732095300601 & LJ-65-20-911 & $3 / 25 / 2010$ & 0932 & Environmental & 2.7 & 175 & 80 & 0.95 & $<6$ & 15.6 \\
\hline 293734095293701 & LJ-65-21-708 & $3 / 25 / 2010$ & 1130 & Environmental & 3.4 & 184 & 101 & .43 & E4 & 16.7 \\
\hline 293736095285301 & LJ-65-21-709 & $3 / 25 / 2010$ & 1257 & Environmental & 2.8 & 186 & 90 & $<.12$ & 46 & 16.6 \\
\hline 294002095351001 & LJ-65-20-414 & $3 / 29 / 2010$ & 1108 & Environmental & 3.8 & 197 & 47 & 1.7 & $<6$ & 13.3 \\
\hline 294414095364202 & LJ-65-20-126 & $3 / 29 / 2010$ & 1313 & Environmental & 3.0 & 214 & 59 & $<.12$ & 448 & 19.5 \\
\hline 294456095341101 & LJ-65-12-820 & $3 / 30 / 2010$ & 0906 & Environmental & 3.1 & 219 & 54 & 2.1 & 7 & 15.6 \\
\hline 294501095343601 & LJ-65-12-817 & $3 / 30 / 2010$ & 1021 & Environmental & 3.4 & 219 & 50 & 2.9 & E4 & 14.1 \\
\hline 294519095383201 & LJ-65-11-918 & $3 / 30 / 2010$ & 1154 & Environmental & 2.5 & 235 & 53 & 1.7 & $<6$ & 12.5 \\
\hline 295246095351301 & LJ-65-04-723 & $3 / 31 / 2010$ & 0913 & Environmental & 2.7 & 228 & 41 & .29 & 44 & 14.9 \\
\hline 295249095364701 & LJ-65-04-728 & $3 / 31 / 2010$ & 1113 & Environmental & 3.2 & 260 & 72 & $<.12$ & 203 & 20.3 \\
\hline 295249095370701 & LJ-65-04-729 & $3 / 31 / 2010$ & 1228 & Environmental & 2.5 & 224 & 47 & .25 & 59 & 16.1 \\
\hline 295243095383101 & LJ-65-03-916 & $4 / 1 / 2010$ & 0941 & Environmental & 2.7 & 250 & 47 & $<.12$ & 154 & 17.9 \\
\hline 294712095401301 & LJ-65-11-803 & $4 / 1 / 2010$ & 1124 & Environmental & 2.5 & 197 & 47 & $<.12$ & 311 & 15.2 \\
\hline 294717095401001 & LJ-65-11-804 & $4 / 1 / 2010$ & 1229 & Environmental & 2.8 & 205 & 49 & $<.12$ & 162 & 15.4 \\
\hline 294952095342601 & LJ-65-12-519 & $4 / 5 / 2010$ & 1030 & Environmental & 2.4 & 203 & 55 & $<.12$ & 214 & 20.1 \\
\hline 294952095342601 & $L J-65-12-519$ & $4 / 5 / 2010$ & 1031 & $\begin{array}{l}\text { Sequential } \\
\quad \text { replicate }\end{array}$ & 2.4 & 204 & 57 & $<.12$ & 201 & 20.4 \\
\hline 294925095341201 & LJ-65-12-520 & $4 / 5 / 2010$ & 1202 & Environmental & 4.1 & 278 & 79 & $<.12$ & 145 & 20.8 \\
\hline 294844095342401 & LJ-65-12-522 & $4 / 5 / 2010$ & 1338 & Environmental & 2.9 & 230 & 66 & $<.12$ & 183 & 20.9 \\
\hline
\end{tabular}


Table 5. Results of trace elements analyses of water samples collected from municipal supply wells in the Houston, Texas, area, 2010-Continued.

\begin{tabular}{|c|c|c|c|c|c|c|c|c|c|c|}
\hline $\begin{array}{l}\text { U.S. Geologi- } \\
\text { cal Survey site } \\
\text { number }\end{array}$ & $\begin{array}{c}\text { State well } \\
\text { number }\end{array}$ & Date & $\begin{array}{c}\text { Sample } \\
\text { start time }\end{array}$ & Sample type & $\begin{array}{c}\text { Arsenic, } \\
\text { water, filtered } \\
(\mu \mathrm{g} / \mathrm{L})\end{array}$ & $\begin{array}{c}\text { Barium, } \\
\text { water, filtered } \\
(\mu \mathrm{g} / \mathrm{L})\end{array}$ & $\begin{array}{l}\text { Boron, water, } \\
\text { filtered } \\
(\mu \mathrm{g} / \mathrm{L})\end{array}$ & $\begin{array}{c}\text { Chromium, } \\
\text { water, filtered } \\
(\mu \mathrm{g} / \mathrm{L})\end{array}$ & $\begin{array}{c}\text { Iron, water, } \\
\text { filtered } \\
(\mu \mathrm{g} / \mathrm{L})\end{array}$ & $\begin{array}{l}\text { Lithium, water, } \\
\text { filtered } \\
(\mu \mathrm{g} / \mathrm{L})\end{array}$ \\
\hline 294800095344101 & LJ-65-12-516 & $4 / 6 / 2010$ & 0920 & Environmental & 5.2 & 189 & 54 & $<0.12$ & 391 & 19.1 \\
\hline 294735095344001 & LJ-65-12-521 & $4 / 6 / 2010$ & 1042 & Environmental & 3.4 & 233 & 71 & $<.12$ & 117 & 21.0 \\
\hline 294627095375801 & LJ-65-11-914 & $4 / 6 / 2010$ & 1216 & Environmental & 2.7 & 231 & 60 & $<.12$ & 58 & 19.9 \\
\hline 294721095361001 & LJ-65-12-719 & $4 / 7 / 2010$ & 0909 & Environmental & 1.9 & 232 & 58 & .75 & 27 & 20.3 \\
\hline 294723095370501 & LJ-65-12-730 & $4 / 7 / 2010$ & 1040 & Environmental & 3.2 & 227 & 58 & $<.12$ & 70 & 20.3 \\
\hline 294723095382601 & LJ-65-11-920 & $4 / 7 / 2010$ & 1209 & Environmental & 3.0 & 221 & 61 & $<.12$ & 102 & 20.0 \\
\hline 294731095414201 & LJ-65-11-514 & $4 / 8 / 2010$ & 1016 & Environmental & 4.7 & 150 & 122 & $<.12$ & 57 & 24.0 \\
\hline 295553095191201 & LJ-65-06-528 & $4 / 8 / 2010$ & 1331 & Environmental & 2.6 & 411 & 56 & $<.12$ & 277 & 13.9 \\
\hline 295027095312301 & LJ-65-12-328 & $5 / 6 / 2010$ & 0940 & Environmental & 22.3 & 340 & 234 & E. 10 & 220 & 24.6 \\
\hline 293636095300401 & JY-65-28-309 & $10 / 28 / 2010$ & 1011 & Environmental & 2.1 & 197 & 62 & .11 & 404 & 15.8 \\
\hline 293635095294101 & JY-65-29-107 & $10 / 28 / 2010$ & 1225 & Environmental & 3.5 & 218 & 190 & $<.06$ & 183 & 21.2 \\
\hline 293652095293601 & LJ-65-29-108 & $10 / 28 / 2010$ & 1350 & Environmental & 3.0 & 233 & 85 & $<.06$ & 304 & 18.5 \\
\hline 294252095362101 & LJ-65-20-125 & $11 / 3 / 2010$ & 1033 & Environmental & 2.1 & 260 & 41 & 1.9 & 7 & 13.1 \\
\hline 294127095342502 & LJ-65-20-519 & $11 / 4 / 2010$ & 0945 & Environmental & 1.6 & 195 & 116 & $<.06$ & 114 & 19.5 \\
\hline 294127095342502 & $L J-65-20-519$ & $11 / 4 / 2010$ & 0946 & $\begin{array}{l}\text { Sequential } \\
\text { replicate }\end{array}$ & 1.7 & 195 & 111 & $<.06$ & 114 & 18.3 \\
\hline 294047095345601 & LJ-65-20-516 & $11 / 4 / 2010$ & 1114 & Environmental & 2.6 & 234 & 39 & 3.3 & 4 & 11.7 \\
\hline 294050095355501 & LJ-65-20-416 & $11 / 9 / 2010$ & 1159 & Environmental & 2.3 & 267 & 38 & 4.5 & 4 & 10.1 \\
\hline
\end{tabular}


Table 5. Results of trace elements analyses of water samples collected from municipal supply wells in the Houston, Texas, area, 2010-Continued.

\begin{tabular}{|c|c|c|c|c|c|c|c|c|c|}
\hline $\begin{array}{l}\text { U.S. Geological } \\
\text { Survey site number }\end{array}$ & $\begin{array}{l}\text { State well } \\
\text { number }\end{array}$ & Date & $\begin{array}{c}\text { Sample start } \\
\text { time }\end{array}$ & Sample type & $\begin{array}{c}\text { Manganese, } \\
\text { water, filtered } \\
(\mu \mathrm{g} / \mathrm{L})\end{array}$ & $\begin{array}{c}\text { Molybdenum, } \\
\text { water, filtered } \\
(\mu \mathrm{g} / \mathrm{L})\end{array}$ & $\begin{array}{c}\text { Selenium, } \\
\text { water, filtered } \\
(\mu \mathrm{g} / \mathrm{L})\end{array}$ & $\begin{array}{c}\text { Strontium, } \\
\text { water, filtered } \\
(\mu \mathrm{g} / \mathrm{L})\end{array}$ & $\begin{array}{c}\text { Vanadium, } \\
\text { water, filtered } \\
(\mu \mathrm{g} / \mathrm{L})\end{array}$ \\
\hline 294921095312907 & LJ-65-12-633 & $3 / 16 / 2010$ & 1041 & Environmental & 1.6 & 0.3 & 0.77 & 465 & 5.0 \\
\hline 294900095312101 & LJ-65-12-619 & $3 / 16 / 2010$ & 1257 & Environmental & 5.5 & 1.3 & 14.1 & 738 & .91 \\
\hline 295027095312301 & LJ-65-12-328 & $3 / 17 / 2010$ & 0927 & Environmental & 6.7 & 12.9 & $<.04$ & 507 & .19 \\
\hline 295027095312301 & $L J-65-12-328$ & $3 / 17 / 2010$ & 0928 & $\begin{array}{l}\text { Sequential } \\
\quad \text { replicate }\end{array}$ & 6.9 & 13.2 & $<.04$ & 510 & E.14 \\
\hline 294950095313701 & LJ-65-12-622 & $3 / 17 / 2010$ & 1114 & Environmental & 5.4 & 1.3 & 2.3 & 632 & .97 \\
\hline 294340095311103 & LJ-65-20-321 & $3 / 18 / 2010$ & 0952 & Environmental & 3.6 & 2.8 & .97 & 380 & 4.5 \\
\hline 294348095303702 & LJ-65-20-319 & $3 / 18 / 2010$ & 1147 & Environmental & 1.9 & 2.2 & 3.8 & 415 & 7.7 \\
\hline 294348095270401 & LJ-65-21-202 & $3 / 22 / 2010$ & 1002 & Environmental & 7.2 & 5.0 & .11 & 360 & .20 \\
\hline 294338095270401 & LJ-65-21-201 & $3 / 22 / 2010$ & 1129 & Environmental & E. 2 & 1.1 & 7.3 & 731 & 6.5 \\
\hline 294333095275602 & LJ-65-21-143 & $3 / 22 / 2010$ & 1304 & Environmental & 4.3 & 2.4 & .74 & 484 & 3.7 \\
\hline 294329095284602 & LJ-65-21-148 & $3 / 23 / 2010$ & 1001 & Environmental & 1.1 & 2.3 & 1.7 & 466 & 8.9 \\
\hline 294329095284602 & $L J-65-21-148$ & $3 / 23 / 2010$ & 1002 & $\begin{array}{l}\text { Sequential } \\
\quad \text { replicate }\end{array}$ & 1.4 & 2.3 & 1.8 & 477 & 9.0 \\
\hline 294319095305901 & LJ-65-20-303 & $3 / 23 / 2010$ & 1123 & Environmental & 1.0 & 1.0 & 5.3 & 510 & 17.0 \\
\hline 294317095313001 & LJ-65-20-304 & $3 / 23 / 2010$ & 1252 & Environmental & 8.3 & 2.9 & 2.4 & 316 & 2.2 \\
\hline 294328095290402 & LJ-65-21-149 & $3 / 24 / 2010$ & 1036 & Environmental & 3.2 & 2.1 & 3.9 & 486 & 8.3 \\
\hline 294323095300103 & LJ-65-20-325 & $3 / 24 / 2010$ & 1151 & Environmental & 7.6 & 3.2 & .41 & 344 & .87 \\
\hline 294201095355601 & LJ-65-20-405 & $3 / 24 / 2010$ & 1343 & Environmental & .5 & .8 & 4.5 & 531 & 4.6 \\
\hline 293732095300601 & LJ-65-20-911 & $3 / 25 / 2010$ & 0932 & Environmental & 4.5 & 2.5 & 4.6 & 388 & 8.1 \\
\hline
\end{tabular}


Table 5. Results of trace elements analyses of water samples collected from municipal supply wells in the Houston, Texas, area, 2010-Continued.

\begin{tabular}{|c|c|c|c|c|c|c|c|c|c|}
\hline $\begin{array}{l}\text { U.S. Geological } \\
\text { Survey site number }\end{array}$ & $\begin{array}{l}\text { State well } \\
\text { number }\end{array}$ & Date & $\begin{array}{l}\text { Sample start } \\
\text { time }\end{array}$ & Sample type & $\begin{array}{c}\text { Manganese, } \\
\text { water, filtered } \\
(\mu \mathrm{g} / \mathrm{L})\end{array}$ & $\begin{array}{c}\text { Molybdenum, } \\
\text { water, filtered } \\
(\mu \mathrm{g} / \mathrm{L})\end{array}$ & $\begin{array}{c}\text { Selenium, } \\
\text { water, filtered } \\
(\mu \mathrm{g} / \mathrm{L})\end{array}$ & $\begin{array}{c}\text { Strontium, } \\
\text { water, filtered } \\
(\mu \mathrm{g} / \mathrm{L})\end{array}$ & $\begin{array}{c}\text { Vanadium, } \\
\text { water, filtered } \\
(\mu \mathrm{g} / \mathrm{L})\end{array}$ \\
\hline 293734095293701 & LJ-65-21-708 & $3 / 25 / 2010$ & 1130 & Environmental & 7.0 & 3.8 & 2.1 & 337 & 4.9 \\
\hline 293736095285301 & LJ-65-21-709 & $3 / 25 / 2010$ & 1257 & Environmental & 14.1 & 3.0 & .48 & 337 & 10.5 \\
\hline 294002095351001 & LJ-65-20-414 & $3 / 29 / 2010$ & 1108 & Environmental & 1.4 & 1.2 & 7.2 & 545 & 12.6 \\
\hline 294414095364202 & LJ-65-20-126 & $3 / 29 / 2010$ & 1313 & Environmental & 20.8 & 2.1 & $<.04$ & 683 & E.11 \\
\hline 294456095341101 & LJ-65-12-820 & $3 / 30 / 2010$ & 0906 & Environmental & 3.3 & 1.4 & 1.2 & 544 & 4.9 \\
\hline 294501095343601 & LJ-65-12-817 & $3 / 30 / 2010$ & 1021 & Environmental & .7 & 1.1 & 2.3 & 513 & 6.0 \\
\hline 294519095383201 & LJ-65-11-918 & 3/30/2010 & 1154 & Environmental & 2.3 & .5 & 2.7 & 427 & 5.1 \\
\hline 295246095351301 & LJ-65-04-723 & $3 / 31 / 2010$ & 0913 & Environmental & 7.3 & 1.2 & 16.8 & 423 & 2.8 \\
\hline 295249095364701 & LJ-65-04-728 & $3 / 31 / 2010$ & 1113 & Environmental & 10.7 & 2.3 & $<.04$ & 589 & .17 \\
\hline 295249095370701 & LJ-65-04-729 & $3 / 31 / 2010$ & 1228 & Environmental & 10.9 & 1.4 & 12.1 & 446 & 4.0 \\
\hline 295243095383101 & LJ-65-03-916 & $4 / 1 / 2010$ & 0941 & Environmental & 9.0 & 1.7 & $<.04$ & 704 & E.14 \\
\hline 294712095401301 & LJ-65-11-803 & $4 / 1 / 2010$ & 1124 & Environmental & 14.9 & 1.9 & $<.04$ & 596 & E.13 \\
\hline 294717095401001 & LJ-65-11-804 & $4 / 1 / 2010$ & 1229 & Environmental & 13.2 & 2.2 & $<.04$ & 588 & E.12 \\
\hline 294952095342601 & LJ-65-12-519 & $4 / 5 / 2010$ & 1030 & Environmental & 13.6 & 2.2 & .04 & 692 & E.16 \\
\hline 294952095342601 & $L J-65-12-519$ & $4 / 5 / 2010$ & 1031 & $\begin{array}{l}\text { Sequential } \\
\quad \text { replicate }\end{array}$ & 13.6 & 2.2 & .05 & 686 & E.15 \\
\hline 294925095341201 & LJ-65-12-520 & $4 / 5 / 2010$ & 1202 & Environmental & 9.7 & 1.8 & $<.04$ & 640 & $<.16$ \\
\hline 294844095342401 & LJ-65-12-522 & $4 / 5 / 2010$ & 1338 & Environmental & 12.9 & 1.7 & $<.04$ & 697 & $<.16$ \\
\hline 294800095344101 & LJ-65-12-516 & $4 / 6 / 2010$ & 0920 & Environmental & 11.0 & 2.3 & $<.04$ & 597 & $<.16$ \\
\hline
\end{tabular}


Table 5. Results of trace elements analyses of water samples collected from municipal supply wells in the Houston, Texas, area, 2010-Continued.

\begin{tabular}{|c|c|c|c|c|c|c|c|c|c|}
\hline $\begin{array}{l}\text { U.S. Geological } \\
\text { Survey site number }\end{array}$ & $\begin{array}{l}\text { State well } \\
\text { number }\end{array}$ & Date & $\begin{array}{c}\text { Sample start } \\
\text { time }\end{array}$ & Sample type & $\begin{array}{c}\text { Manganese, } \\
\text { water, filtered } \\
(\mu \mathrm{g} / \mathrm{L})\end{array}$ & $\begin{array}{c}\text { Molybdenum, } \\
\text { water, filtered } \\
(\mu \mathrm{g} / \mathrm{L})\end{array}$ & $\begin{array}{c}\text { Selenium, } \\
\text { water, filtered } \\
(\mu \mathrm{g} / \mathrm{L})\end{array}$ & $\begin{array}{c}\text { Strontium, } \\
\text { water, filtered } \\
(\mu \mathrm{g} / \mathrm{L})\end{array}$ & $\begin{array}{c}\text { Vanadium, } \\
\text { water, filtered } \\
(\mu \mathrm{g} / \mathrm{L})\end{array}$ \\
\hline 294735095344001 & LJ-65-12-521 & $4 / 6 / 2010$ & 1042 & Environmental & 13.7 & 2.7 & $<0.04$ & 658 & $<0.16$ \\
\hline 294627095375801 & LJ-65-11-914 & $4 / 6 / 2010$ & 1216 & Environmental & 13.5 & 2.2 & $<.04$ & 632 & .28 \\
\hline 294721095361001 & LJ-65-12-719 & $4 / 7 / 2010$ & 0909 & Environmental & 4.5 & 1.4 & 4.9 & 668 & 2.5 \\
\hline 294723095370501 & LJ-65-12-730 & $4 / 7 / 2010$ & 1040 & Environmental & 12.7 & 1.9 & $<.04$ & 632 & $<.16$ \\
\hline 294723095382601 & LJ-65-11-920 & $4 / 7 / 2010$ & 1209 & Environmental & 9.6 & 2.3 & $<.04$ & 603 & $<.16$ \\
\hline 294731095414201 & LJ-65-11-514 & $4 / 8 / 2010$ & 1016 & Environmental & 14.5 & 4.7 & $<.04$ & 412 & $<.16$ \\
\hline 295553095191201 & LJ-65-06-528 & $4 / 8 / 2010$ & 1331 & Environmental & 36.4 & 1.7 & 1.0 & 478 & .63 \\
\hline 295027095312301 & LJ-65-12-328 & $5 / 6 / 2010$ & 0940 & Environmental & 6.9 & 12.9 & $<.04$ & 563 & .50 \\
\hline 293636095300401 & JY-65-28-309 & $10 / 28 / 2010$ & 1011 & Environmental & 56.3 & 2.2 & $<.03$ & 381 & $<.08$ \\
\hline 293635095294101 & JY-65-29-107 & $10 / 28 / 2010$ & 1225 & Environmental & 45.1 & 13.2 & $<.03$ & 404 & $<.08$ \\
\hline 293652095293601 & LJ-65-29-108 & $10 / 28 / 2010$ & 1350 & Environmental & 42.3 & 5.0 & $<.03$ & 434 & $<.08$ \\
\hline 294252095362101 & LJ-65-20-125 & $11 / 3 / 2010$ & 1033 & Environmental & 1.3 & .9 & 3.0 & 570 & 2.7 \\
\hline 294127095342502 & LJ-65-20-519 & $11 / 4 / 2010$ & 0945 & Environmental & 14.2 & 5.2 & $<.03$ & 442 & $<.08$ \\
\hline 294127095342502 & $L J-65-20-519$ & $11 / 4 / 2010$ & 0946 & $\begin{array}{l}\text { Sequential } \\
\quad \text { replicate }\end{array}$ & 14.2 & 5.2 & $<.03$ & 443 & $<.08$ \\
\hline 294047095345601 & LJ-65-20-516 & $11 / 4 / 2010$ & 1114 & Environmental & 1.8 & .8 & 11.4 & 574 & 8.4 \\
\hline 294050095355501 & LJ-65-20-416 & $11 / 9 / 2010$ & 1159 & Environmental & .4 & .3 & 2.0 & 522 & 4.9 \\
\hline
\end{tabular}


Table 6. Results of radionuclide analyses of water samples collected from municipal supply wells in the Houston, Texas, area, 2010.

[Contaminant concentrations that are greater than U.S. Environmental Protection Agency maximum contaminant level (MCL) do not represent MCL violations because MCLs apply to finished water, and all samples were collected from source waters. None of the source-water samples were collected for regulatory compliance purposes; further, compliance with most MCLs is based on running average concentrations, not on concentrations detected in single samples as collected in this study. Rounding of each radionuclide result is unique, based on significant digits of the associated combined standard uncertainty (CSU). Th, thorium; $\mathrm{pCi} / \mathrm{L}$, picocuries per liter; $\mathrm{ssL}_{\mathrm{C}}$, sample-specific critical level; R, nondetected result less than ssL; $\mathrm{b}_{\mathrm{C}}$, sample-specific minimum detectable concentration greater than contractual a priori method detectable concentration; --, no data available; Cs, cesium; e, laboratory blank greater than the $\mathrm{ssL}_{\mathrm{c}} ;<$, less than; c, analyses counted 4 days after sample collection; $\mathrm{LRL}$, laboratory reporting level; LT-MDL, long term method detection level; $\mu \mathrm{g} / \mathrm{L}$, micrograms per liter]

\begin{tabular}{|c|c|c|c|c|c|c|c|c|c|c|c|c|}
\hline $\begin{array}{l}\text { U.S. Geological } \\
\text { Survey site number }\end{array}$ & $\begin{array}{c}\text { State well } \\
\text { number }\end{array}$ & Date & $\begin{array}{c}\text { Sample } \\
\text { start } \\
\text { time }\end{array}$ & Sample type & $\begin{array}{c}\text { Alpha } \\
\text { radioactiv- } \\
\text { ity, 30-day } \\
\text { count, water, } \\
\text { filtered, } \\
\text { Th-230 curve } \\
\text { (pCi/L) }\end{array}$ & $\begin{array}{l}\text { Alpha radio- } \\
\text { activity, 30- } \\
\text { day count, } \\
\text { 1-sigma } \\
\text { CSU, water, } \\
\text { filtered, } \\
\text { Th-230 curve } \\
\text { (pCi/L) }\end{array}$ & $\begin{array}{l}\text { Alpha radio- } \\
\text { activity, } 30 \text { - } \\
\text { day count, } \\
\text { ssL, water, }_{c} \text {, } \\
\text { filtered, } \\
\text { Th-230 curve } \\
\text { (pCi/L) }\end{array}$ & $\begin{array}{c}\text { Alpha } \\
\text { radioactiv- } \\
\text { ity, 30-day } \\
\text { count } \\
\text { (remark } \\
\text { code) }\end{array}$ & $\begin{array}{c}\text { Alpha } \\
\text { radioactiv- } \\
\text { ity, 72-hour } \\
\text { count, wa- } \\
\text { ter, filtered, } \\
\text { Th-230 curve } \\
\text { (pCi/L) }\end{array}$ & $\begin{array}{l}\text { Alpha radio- } \\
\text { activity, 72- } \\
\text { hour count, } \\
\text { 1-sigma } \\
\text { CSU, water, } \\
\text { filtered, } \\
\text { Th-230 curve } \\
\text { (pCi/L) }\end{array}$ & $\begin{array}{l}\text { Alpha radio- } \\
\text { activity, 72- } \\
\text { hour count, } \\
\text { ssLC, water, } \\
\text { filtered, } \\
\text { Th-230 curve } \\
\text { (pCi/L) }\end{array}$ & $\begin{array}{l}\text { Alpha } \\
\text { radioac- } \\
\text { tivity, 72- } \\
\text { hour count } \\
\text { (remark } \\
\text { code) }\end{array}$ \\
\hline 294921095312907 & LJ-65-12-633 & $3 / 16 / 2010$ & 1041 & Environmental & 8.6 & 1.8 & 1.9 & $\mathrm{~b}$ & 20.1 & 2.8 & 1.9 & $\mathrm{~b}$ \\
\hline 294900095312101 & LJ-65-12-619 & $3 / 16 / 2010$ & 1257 & Environmental & 9.5 & 1.4 & .61 & -- & 12.3 & 1.7 & .62 & -- \\
\hline 295027095312301 & LJ-65-12-328 & $3 / 17 / 2010$ & 0927 & Environmental & 4.43 & .88 & .41 & -- & 6.6 & 1.2 & .75 & -- \\
\hline 295027095312301 & $L J-65-12-328$ & $3 / 17 / 2010$ & 0928 & $\begin{array}{l}\text { Sequential } \\
\quad \text { replicate }\end{array}$ & 3.01 & .72 & .54 & -- & 9.8 & 1.5 & .73 & -- \\
\hline 294950095313701 & LJ-65-12-622 & $3 / 17 / 2010$ & 1114 & Environmental & 8.6 & 1.3 & .54 & -- & 15 & 2 & .65 & -- \\
\hline 294340095311103 & LJ-65-20-321 & $3 / 18 / 2010$ & 0952 & Environmental & 4.32 & .92 & .85 & -- & 8.0 & 1.2 & .58 & -- \\
\hline 294348095303702 & LJ-65-20-319 & $3 / 18 / 2010$ & 1147 & Environmental & 7 & 1 & .31 & -- & 12.5 & 1.7 & .57 & -- \\
\hline 294348095270401 & LJ-65-21-202 & $3 / 22 / 2010$ & 1002 & Environmental & 4.26 & .83 & .68 & -- & 4.36 & .83 & .57 & -- \\
\hline 294338095270401 & LJ-65-21-201 & $3 / 22 / 2010$ & 1129 & Environmental & 9.8 & 1.3 & .49 & -- & 13.7 & 1.7 & .41 & -- \\
\hline 294333095275602 & LJ-65-21-143 & $3 / 22 / 2010$ & 1304 & Environmental & 8.4 & 1.2 & .69 & -- & 6.12 & .98 & .55 & -- \\
\hline 294329095284602 & LJ-65-21-148 & $3 / 23 / 2010$ & 1001 & Environmental & 20.9 & 2.5 & .39 & -- & 12.9 & 1.7 & .53 & -- \\
\hline 294329095284602 & $L J-65-21-148$ & $3 / 23 / 2010$ & 1002 & $\begin{array}{l}\text { Sequential } \\
\text { replicate }\end{array}$ & 16.1 & 2.2 & .97 & -- & 13.6 & 1.8 & .59 & -- \\
\hline 294319095305901 & LJ-65-20-303 & $3 / 23 / 2010$ & 1123 & Environmental & 6.1 & 1.1 & .76 & -- & 13.2 & 1.8 & .54 & -- \\
\hline
\end{tabular}




\begin{tabular}{|c|c|c|c|c|c|c|c|c|c|c|c|c|}
\hline $\begin{array}{l}\text { U.S. Geological } \\
\text { Survey site number }\end{array}$ & $\begin{array}{l}\text { State well } \\
\text { number }\end{array}$ & Date & $\begin{array}{c}\text { Sample } \\
\text { start } \\
\text { time }\end{array}$ & Sample type & $\begin{array}{c}\text { Alpha } \\
\text { radioactiv- } \\
\text { ity, 30-day } \\
\text { count, water, } \\
\text { filtered, } \\
\text { Th-230 curve } \\
\text { (pCi/L)1 }\end{array}$ & $\begin{array}{l}\text { Alpha radio- } \\
\text { activity, 30- } \\
\text { day count, } \\
\text { 1-sigma } \\
\text { CSU, water, } \\
\text { filtered, } \\
\text { Th-230 curve } \\
\text { (pCi/L) }\end{array}$ & $\begin{array}{l}\text { Alpha radio- } \\
\text { activity, } 30- \\
\text { day count, } \\
\text { ssL }_{c^{\prime}} \text { water, } \\
\text { filtered, } \\
\text { Th-230 curve } \\
\text { (pCi/L) }\end{array}$ & $\begin{array}{l}\text { Alpha } \\
\text { radioactiv- } \\
\text { ity, 30-day } \\
\text { count } \\
\text { (remark } \\
\text { code) }\end{array}$ & $\begin{array}{c}\text { Alpha } \\
\text { radioactiv- } \\
\text { ity, 72-hour } \\
\text { count, wa- } \\
\text { ter, filtered, } \\
\text { Th-230 curve } \\
\text { (pCi/L)1 }\end{array}$ & $\begin{array}{l}\text { Alpha radio- } \\
\text { activity, 72- } \\
\text { hour count, } \\
\text { 1-sigma } \\
\text { CSU, water, } \\
\text { filtered, } \\
\text { Th-230 curve } \\
\text { (pCi/L) }\end{array}$ & $\begin{array}{l}\text { Alpha radio- } \\
\text { activity, 72- } \\
\text { hour count, } \\
\text { ssLC, water, } \\
\text { filtered, } \\
\text { Th-230 curve } \\
\text { (pCi/L) }\end{array}$ & $\begin{array}{l}\text { Alpha } \\
\text { radioac- } \\
\text { tivity, 72- } \\
\text { hour count } \\
\text { (remark } \\
\text { code) }\end{array}$ \\
\hline 294317095313001 & LJ-65-20-304 & $3 / 23 / 2010$ & 1252 & Environmental & 5 & 1 & 0.79 & -- & 8.6 & 1.3 & 0.65 & -- \\
\hline 294328095290402 & LJ-65-21-149 & $3 / 24 / 2010$ & 1036 & Environmental & 6.7 & 1.1 & .56 & -- & 14.8 & 2.2 & .76 & -- \\
\hline 294323095300103 & LJ-65-20-325 & $3 / 24 / 2010$ & 1151 & Environmental & 4.45 & .84 & .49 & -- & 7.7 & 1.2 & .55 & -- \\
\hline 294201095355601 & LJ-65-20-405 & $3 / 24 / 2010$ & 1343 & Environmental & 6 & 1 & .64 & -- & 13 & 2 & .69 & -- \\
\hline 293732095300601 & LJ-65-20-911 & $3 / 25 / 2010$ & 0932 & Environmental & 7.9 & 1.3 & .96 & -- & 11.9 & 1.7 & .71 & -- \\
\hline 293734095293701 & LJ-65-21-708 & $3 / 25 / 2010$ & 1130 & Environmental & 7.3 & 1.2 & .61 & -- & 10.7 & 1.5 & .5 & -- \\
\hline 293736095285301 & LJ-65-21-709 & $3 / 25 / 2010$ & 1257 & Environmental & 7.0 & 1.2 & .84 & -- & 15 & 2 & .46 & -- \\
\hline 294002095351001 & LJ-65-20-414 & $3 / 29 / 2010$ & 1108 & Environmental & 10.6 & 1.5 & .66 & -- & 16.0 & 2.1 & .68 & -- \\
\hline 294414095364202 & LJ-65-20-126 & $3 / 29 / 2010$ & 1313 & Environmental & 1.66 & .53 & .58 & -- & 2.58 & .66 & .61 & -- \\
\hline 294456095341101 & LJ-65-12-820 & $3 / 30 / 2010$ & 0906 & Environmental & 6.8 & 1.1 & .57 & -- & 10.3 & 1.4 & .59 & -- \\
\hline 294501095343601 & LJ-65-12-817 & $3 / 30 / 2010$ & 1021 & Environmental & 5.6 & .9 & .53 & -- & 7.9 & 1.2 & .56 & -- \\
\hline 294519095383201 & LJ-65-11-918 & $3 / 30 / 2010$ & 1154 & Environmental & 4.90 & .82 & .52 & -- & 10.7 & 1.4 & .52 & -- \\
\hline 295246095351301 & LJ-65-04-723 & $3 / 31 / 2010$ & 0913 & Environmental & 25.5 & 3.9 & .96 & -- & 31.0 & 3.5 & .6 & -- \\
\hline 295249095364701 & LJ-65-04-728 & $3 / 31 / 2010$ & 1113 & Environmental & 6.7 & 1.1 & .57 & -- & 6.8 & 1.1 & .61 & -- \\
\hline 295249095370701 & LJ-65-04-729 & $3 / 31 / 2010$ & 1228 & Environmental & 21.7 & 3.5 & 1.1 & -- & 39.7 & 4.4 & .44 & -- \\
\hline 295243095383101 & LJ-65-03-916 & $4 / 1 / 2010$ & 0941 & Environmental & 10.6 & 1.5 & .62 & -- & 8.8 & 1.3 & .67 & -- \\
\hline
\end{tabular}


Table 6. Results of radionuclide analyses of water samples collected from municipal supply wells in the Houston, Texas, area, 2010-Continued.

\begin{tabular}{|c|c|c|c|c|c|c|c|c|c|c|c|c|}
\hline $\begin{array}{l}\text { U.S. Geological } \\
\text { Survey site number }\end{array}$ & $\begin{array}{l}\text { State well } \\
\text { number }\end{array}$ & Date & $\begin{array}{c}\text { Sample } \\
\text { start } \\
\text { time }\end{array}$ & Sample type & $\begin{array}{c}\text { Alpha } \\
\text { radioactiv- } \\
\text { ity, 30-day } \\
\text { count, water, } \\
\text { filtered, } \\
\text { Th-230 curve } \\
\text { (pCi/L) }\end{array}$ & $\begin{array}{l}\text { Alpha radio- } \\
\text { activity, } 30- \\
\text { day count, } \\
\text { 1-sigma } \\
\text { CSU, water, } \\
\text { filtered, } \\
\text { Th-230 curve } \\
\text { (pCi/L) }\end{array}$ & $\begin{array}{l}\text { Alpha radio- } \\
\text { activity, } 30 \text { - } \\
\text { day count, } \\
\text { ssL }_{c} \text {, water, } \\
\text { filtered, } \\
\text { Th-230 curve } \\
\text { (pCi/L) }\end{array}$ & $\begin{array}{c}\text { Alpha } \\
\text { radioactiv- } \\
\text { ity, 30-day } \\
\text { count } \\
\text { (remark } \\
\text { code) }\end{array}$ & $\begin{array}{c}\text { Alpha } \\
\text { radioactiv- } \\
\text { ity, 72-hour } \\
\text { count, wa- } \\
\text { ter, filtered, } \\
\text { Th-230 curve } \\
\text { (pCi/L)1 }\end{array}$ & $\begin{array}{l}\text { Alpha radio- } \\
\text { activity, 72- } \\
\text { hour count, } \\
\text { 1-sigma } \\
\text { CSU, water, } \\
\text { filtered, } \\
\text { Th-230 curve } \\
\text { (pCi/L) }\end{array}$ & $\begin{array}{l}\text { Alpha radio- } \\
\text { activity, } 72- \\
\text { hour count, } \\
\text { ssLC, water, } \\
\text { filtered, } \\
\text { Th-230 curve } \\
\text { (pCi/L) }\end{array}$ & $\begin{array}{l}\text { Alpha } \\
\text { radioac- } \\
\text { tivity, 72- } \\
\text { hour count } \\
\text { (remark } \\
\text { code) }\end{array}$ \\
\hline 294712095401301 & LJ-65-11-803 & $4 / 1 / 2010$ & 1124 & Environmental & 20.4 & 2.5 & 0.58 & -- & 13.1 & 1.7 & 0.61 & -- \\
\hline 294717095401001 & LJ-65-11-804 & $4 / 1 / 2010$ & 1229 & Environmental & 10.4 & 1.5 & .54 & -- & 12.8 & 1.7 & .66 & -- \\
\hline 294952095342601 & LJ-65-12-519 & $4 / 5 / 2010$ & 1030 & Environmental & 4.32 & .79 & .53 & -- & 7 & 1 & .47 & $\mathrm{e}$ \\
\hline 294952095342601 & $L J-65-12-519$ & $4 / 5 / 2010$ & 1031 & $\begin{array}{l}\text { Sequential } \\
\text { replicate }\end{array}$ & 4.44 & .84 & .57 & -- & 5.26 & .92 & .54 & $e$ \\
\hline 294925095341201 & LJ-65-12-520 & $4 / 5 / 2010$ & 1202 & Environmental & 16.5 & 2.1 & .55 & -- & 7.6 & 1.4 & 1.4 & $\mathrm{e}$ \\
\hline 294844095342401 & LJ-65-12-522 & $4 / 5 / 2010$ & 1338 & Environmental & 12.4 & 1.6 & .44 & -- & 7.4 & 1.1 & .5 & e \\
\hline 294800095344101 & LJ-65-12-516 & $4 / 6 / 2010$ & 0920 & Environmental & 3.18 & .73 & 6 & -- & 5.73 & .99 & .59 & $\mathrm{e}$ \\
\hline 294735095344001 & LJ-65-12-521 & $4 / 6 / 2010$ & 1042 & Environmental & 4.26 & .83 & .58 & -- & 10.4 & 1.5 & .45 & $\mathrm{e}$ \\
\hline 294627095375801 & LJ-65-11-914 & $4 / 6 / 2010$ & 1216 & Environmental & 3.04 & .68 & .57 & -- & 6.9 & 1.1 & 6 & $\mathrm{e}$ \\
\hline 294721095361001 & LJ-65-12-719 & 4/7/2010 & 0909 & Environmental & 6 & 1 & .61 & e & 11.6 & 1.6 & .56 & $\mathrm{e}$ \\
\hline 294723095370501 & LJ-65-12-730 & $4 / 7 / 2010$ & 1040 & Environmental & 3.73 & .71 & .54 & $\mathrm{e}$ & 6 & 1 & .62 & $\mathrm{e}$ \\
\hline 294723095382601 & LJ-65-11-920 & $4 / 7 / 2010$ & 1209 & Environmental & 3.88 & .76 & .57 & e & 7.3 & 1.1 & .49 & e \\
\hline 294731095414201 & LJ-65-11-514 & $4 / 8 / 2010$ & 1016 & Environmental & 2.5 & 1.4 & 2 & $e, b$ & 5.7 & 1.1 & .76 & $\mathrm{e}$ \\
\hline 295553095191201 & LJ-65-06-528 & $4 / 8 / 2010$ & 1331 & Environmental & 2.48 & .56 & .47 & $\mathrm{e}$ & 5.03 & .87 & .55 & $\mathrm{e}$ \\
\hline 295027095312301 & LJ-65-12-328 & $5 / 6 / 2010$ & 0940 & Environmental & -- & -- & -- & -- & -- & -- & -- & -- \\
\hline 293636095300401 & JY-65-28-309 & $10 / 28 / 2010$ & 1011 & Environmental & 13.4 & 1.9 & .76 & -- & 13.2 & 1.8 & .67 & -- \\
\hline
\end{tabular}




\begin{tabular}{|c|c|c|c|c|c|c|c|c|c|c|c|c|}
\hline $\begin{array}{l}\text { U.S. Geological } \\
\text { Survey site number }\end{array}$ & $\begin{array}{l}\text { State well } \\
\text { number }\end{array}$ & Date & $\begin{array}{c}\text { Sample } \\
\text { start } \\
\text { time }\end{array}$ & Sample type & $\begin{array}{c}\text { Alpha } \\
\text { radioactiv- } \\
\text { ity, 30-day } \\
\text { count, water, } \\
\text { filtered, } \\
\text { Th-230 curve } \\
\text { (pCi/L)1 }\end{array}$ & $\begin{array}{l}\text { Alpha radio- } \\
\text { activity, 30- } \\
\text { day count, } \\
\text { 1-sigma } \\
\text { CSU, water, } \\
\text { filtered, } \\
\text { Th-230 curve } \\
\text { (pCi/L) }\end{array}$ & $\begin{array}{l}\text { Alpha radio- } \\
\text { activity, } 30- \\
\text { day count, } \\
\text { ssL, water, } \\
\text { filtered, } \\
\text { Th-230 curve } \\
\text { (pCi/L) }\end{array}$ & $\begin{array}{l}\text { Alpha } \\
\text { radioactiv- } \\
\text { ity, 30-day } \\
\text { count } \\
\text { (remark } \\
\text { code) }\end{array}$ & $\begin{array}{c}\text { Alpha } \\
\text { radioactiv- } \\
\text { ity, } 72 \text {-hour } \\
\text { count, wa- } \\
\text { ter, filtered, } \\
\text { Th-230 curve } \\
(\mathrm{pCi} / \mathrm{L})^{1}\end{array}$ & $\begin{array}{c}\text { Alpha radio- } \\
\text { activity, 72- } \\
\text { hour count, } \\
\text { 1-sigma } \\
\text { CSU, water, } \\
\text { filtered, } \\
\text { Th-230 curve } \\
\text { (pCi/L) }\end{array}$ & $\begin{array}{l}\text { Alpha radio- } \\
\text { activity, 72- } \\
\text { hour count, } \\
\text { ssLC, water, } \\
\text { filtered, } \\
\text { Th-230 curve } \\
\text { (pCi/L) }\end{array}$ & $\begin{array}{l}\text { Alpha } \\
\text { radioac- } \\
\text { tivity, 72- } \\
\text { hour count } \\
\text { (remark } \\
\text { code) }\end{array}$ \\
\hline 293635095294101 & JY-65-29-107 & $10 / 28 / 2010$ & 1225 & Environmental & 8.2 & 1.4 & 0.85 & -- & 16.9 & 2.4 & 0.87 & -- \\
\hline 293652095293601 & LJ-65-29-108 & $10 / 28 / 2010$ & 1350 & Environmental & 16.1 & 2.7 & 1.2 & -- & 29.1 & 3.5 & .78 & -- \\
\hline 294252095362101 & LJ-65-20-125 & $11 / 3 / 2010$ & 1033 & Environmental & 5.9 & 1.4 & 1 & $\mathrm{e}$ & 10.5 & 1.5 & .64 & $\mathrm{c}$ \\
\hline 294127095342502 & LJ-65-20-519 & $11 / 4 / 2010$ & 0945 & Environmental & .60 & .65 & .87 & $\mathrm{R}$ & 3.07 & .77 & .67 & -- \\
\hline 294127095342502 & $L J-65-20-519$ & $11 / 4 / 2010$ & 0946 & $\begin{array}{l}\text { Sequential } \\
\quad \text { replicate }\end{array}$ & 2.3 & 1.2 & 1.2 & $b$ & 4.8 & 1.2 & 1 & -- \\
\hline 294047095345601 & LJ-65-20-516 & $11 / 4 / 2010$ & 1114 & Environmental & 6.7 & 1.1 & .73 & -- & 17.9 & 2.3 & .73 & -- \\
\hline 294050095355501 & LJ-65-20-416 & $11 / 9 / 2010$ & 1159 & Environmental & 2.97 & .95 & .85 & -- & 11.5 & 1.7 & .78 & -- \\
\hline
\end{tabular}


Table 6. Results of radionuclide analyses of water samples collected from municipal supply wells in the Houston, Texas, area, 2010-Continued.

\begin{tabular}{|c|c|c|c|c|c|c|c|c|c|c|c|c|}
\hline $\begin{array}{l}\text { U.S. Geological Sur- } \\
\text { vey site number }\end{array}$ & $\begin{array}{l}\text { State well } \\
\text { number }\end{array}$ & Date & $\begin{array}{c}\text { Sample } \\
\text { start } \\
\text { time }\end{array}$ & Sample type & $\begin{array}{l}\text { Beta radio- } \\
\text { activity, } 30- \\
\text { day count, } \\
\text { water, } \\
\text { filtered, } \\
\text { Cs-137 } \\
\text { curve } \\
\text { (pCi/L)' }\end{array}$ & $\begin{array}{c}\text { Beta radio- } \\
\text { activity, 30- } \\
\text { day count, } \\
\text { 1-sigma } \\
\text { CSU, water, } \\
\text { filtered, } \\
\text { Cs-137 curve } \\
\text { (pCi/L) }\end{array}$ & $\begin{array}{c}\text { Beta radio- } \\
\text { activity, 30- } \\
\text { day count, } \\
\text { ssLC, water, } \\
\text { filtered, } \\
\text { Cs-137 } \\
\text { curve } \\
\text { (pCi/L) }\end{array}$ & $\begin{array}{c}\text { Beta } \\
\text { radio- } \\
\text { activity, } \\
\text { 30-day } \\
\text { count } \\
\text { (remark } \\
\text { code) }\end{array}$ & $\begin{array}{c}\text { Beta } \\
\text { radioactiv- } \\
\text { ity, 72-hour } \\
\text { count, } \\
\text { water, } \\
\text { filtered, } \\
\text { Cs-137 curve } \\
\text { (pCi/L)' }\end{array}$ & $\begin{array}{c}\text { Beta radio- } \\
\text { activity, } 72- \\
\text { hour count, } \\
\text { 1-sigma CSU, } \\
\text { water, fil- } \\
\text { tered, Cs-137 } \\
\text { curve } \\
\text { (pCi/L) }\end{array}$ & $\begin{array}{l}\text { Beta radio- } \\
\text { activity, 72- } \\
\text { hour count, } \\
\text { ssL } \mathrm{c}_{\text {, }} \text { water, } \\
\text { filtered, } \\
\text { Cs-137 } \\
\text { curve } \\
\text { (pCi/L) }\end{array}$ & $\begin{array}{c}\text { Beta } \\
\text { radio- } \\
\text { activity, } \\
\text { 72-hour } \\
\text { count } \\
\text { (remark } \\
\text { code) }\end{array}$ \\
\hline 294921095312907 & LJ-65-12-633 & $3 / 16 / 2010$ & 1041 & Environmental & 3.72 & 0.59 & 0.79 & -- & 4.4 & 0.6 & 0.79 & -- \\
\hline 294900095312101 & LJ-65-12-619 & $3 / 16 / 2010$ & 1257 & Environmental & 4.0 & .5 & .61 & -- & 3.22 & .47 & 6 & -- \\
\hline 295027095312301 & LJ-65-12-328 & $3 / 17 / 2010$ & 0927 & Environmental & 3.11 & .58 & .78 & -- & 3.73 & .59 & .75 & -- \\
\hline 295027095312301 & $L J-65-12-328$ & $3 / 17 / 2010$ & 0928 & $\begin{array}{l}\text { Sequential } \\
\text { replicate }\end{array}$ & 4.56 & .65 & .92 & -- & 2.87 & .62 & .91 & -- \\
\hline 294950095313701 & LJ-65-12-622 & $3 / 17 / 2010$ & 1114 & Environmental & 6.66 & .62 & .66 & -- & 2.64 & .43 & .58 & -- \\
\hline 294340095311103 & LJ-65-20-321 & $3 / 18 / 2010$ & 0952 & Environmental & 5.9 & 6 & .63 & -- & 2.37 & .42 & .58 & -- \\
\hline 294348095303702 & LJ-65-20-319 & $3 / 18 / 2010$ & 1147 & Environmental & 3.63 & .47 & .6 & -- & 2.43 & .41 & .57 & -- \\
\hline 294348095270401 & LJ-65-21-202 & $3 / 22 / 2010$ & 1002 & Environmental & 2.31 & .37 & .49 & -- & 1.97 & .39 & .54 & -- \\
\hline 294338095270401 & LJ-65-21-201 & $3 / 22 / 2010$ & 1129 & Environmental & 5.97 & .52 & .5 & -- & 3.74 & .46 & .58 & -- \\
\hline 294333095275602 & LJ-65-21-143 & $3 / 22 / 2010$ & 1304 & Environmental & 4.6 & 6 & .83 & -- & 2.49 & .38 & .49 & -- \\
\hline 294329095284602 & LJ-65-21-148 & $3 / 23 / 2010$ & 1001 & Environmental & 6.20 & .65 & .74 & -- & 3.54 & .46 & .56 & -- \\
\hline 294329095284602 & $L J-65-21-148$ & $3 / 23 / 2010$ & 1002 & $\begin{array}{l}\text { Sequential } \\
\quad \text { replicate }\end{array}$ & 5.81 & .64 & .64 & -- & 2.87 & .51 & .71 & -- \\
\hline 294319095305901 & LJ-65-20-303 & $3 / 23 / 2010$ & 1123 & Environmental & 4.13 & .52 & .65 & -- & 3.03 & .67 & .98 & -- \\
\hline 294317095313001 & LJ-65-20-304 & $3 / 23 / 2010$ & 1252 & Environmental & 2.74 & .52 & .78 & -- & 2.5 & .4 & .54 & -- \\
\hline 294328095290402 & LJ-65-21-149 & $3 / 24 / 2010$ & 1036 & Environmental & 4.64 & .49 & .58 & -- & 3.30 & .53 & .68 & -- \\
\hline 294323095300103 & LJ-65-20-325 & $3 / 24 / 2010$ & 1151 & Environmental & 2.83 & .41 & .54 & -- & 1.99 & .48 & .7 & -- \\
\hline 294201095355601 & LJ-65-20-405 & $3 / 24 / 2010$ & 1343 & Environmental & 4.70 & .46 & .5 & -- & 3.11 & .58 & .81 & -- \\
\hline 293732095300601 & LJ-65-20-911 & $3 / 25 / 2010$ & 0932 & Environmental & 4.4 & 6 & .72 & -- & 2.8 & .5 & .69 & -- \\
\hline
\end{tabular}




\begin{tabular}{|c|c|c|c|c|c|c|c|c|c|c|c|c|}
\hline $\begin{array}{l}\text { U.S. Geological Sur- } \\
\text { vey site number }\end{array}$ & $\begin{array}{l}\text { State well } \\
\text { number }\end{array}$ & Date & $\begin{array}{c}\text { Sample } \\
\text { start } \\
\text { time }\end{array}$ & Sample type & $\begin{array}{c}\text { Beta radio- } \\
\text { activity, } 30- \\
\text { day count, } \\
\text { water, } \\
\text { filtered, } \\
\text { Cs-137 } \\
\text { curve } \\
\text { (pCi/L)' }\end{array}$ & $\begin{array}{c}\text { Beta radio- } \\
\text { activity, 30- } \\
\text { day count, } \\
\text { 1-sigma } \\
\text { CSU, water, } \\
\text { filtered, } \\
\text { Cs-137 curve } \\
\text { (pCi/L) }\end{array}$ & $\begin{array}{l}\text { Beta radio- } \\
\text { activity, 30- } \\
\text { day count, } \\
\text { ssLC, water, } \\
\text { filtered, } \\
\text { Cs-137 } \\
\text { curve } \\
\text { (pCi/L) }\end{array}$ & $\begin{array}{c}\text { Beta } \\
\text { radio- } \\
\text { activity, } \\
\text { 30-day } \\
\text { count } \\
\text { (remark } \\
\text { code) }\end{array}$ & $\begin{array}{c}\text { Beta } \\
\text { radioactiv- } \\
\text { ity, 72-hour } \\
\text { count, } \\
\text { water, } \\
\text { filtered, } \\
\text { Cs-137 curve } \\
\text { (pCi/L)' }\end{array}$ & $\begin{array}{c}\text { Beta radio- } \\
\text { activity, } 72- \\
\text { hour count, } \\
\text { 1-sigma CSU, } \\
\text { water, fil- } \\
\text { tered, Cs-137 } \\
\text { curve } \\
\text { (pCi/L) }\end{array}$ & $\begin{array}{l}\text { Beta radio- } \\
\text { activity, 72- } \\
\text { hour count, } \\
\text { ssL } \mathrm{L}_{\mathrm{c}^{\prime}} \text { water, } \\
\text { filtered, } \\
\text { Cs-137 } \\
\text { curve } \\
\text { (pCi/L) }\end{array}$ & $\begin{array}{c}\text { Beta } \\
\text { radio- } \\
\text { activity, } \\
\text { 72-hour } \\
\text { count } \\
\text { (remark } \\
\text { code) }\end{array}$ \\
\hline 293734095293701 & LJ-65-21-708 & $3 / 25 / 2010$ & 1130 & Environmental & 3.69 & 0.52 & 0.66 & -- & 2.89 & 0.49 & 0.65 & -- \\
\hline 293736095285301 & LJ-65-21-709 & $3 / 25 / 2010$ & 1257 & Environmental & 4.48 & .65 & .92 & -- & 2.47 & .49 & .68 & -- \\
\hline 294002095351001 & LJ-65-20-414 & $3 / 29 / 2010$ & 1108 & Environmental & 7.72 & .66 & .62 & -- & 3.49 & .49 & .61 & -- \\
\hline 294414095364202 & LJ-65-20-126 & $3 / 29 / 2010$ & 1313 & Environmental & 2.20 & .46 & .68 & -- & 2.67 & .47 & .67 & -- \\
\hline 294456095341101 & LJ-65-12-820 & $3 / 30 / 2010$ & 0906 & Environmental & 3.4 & .4 & .49 & -- & 3.3 & .4 & .48 & -- \\
\hline 294501095343601 & LJ-65-12-817 & $3 / 30 / 2010$ & 1021 & Environmental & 3.06 & .43 & .57 & -- & 3.86 & .45 & .57 & -- \\
\hline 294519095383201 & LJ-65-11-918 & $3 / 30 / 2010$ & 1154 & Environmental & 2.45 & .34 & .43 & -- & 2.56 & .35 & .43 & -- \\
\hline 295246095351301 & LJ-65-04-723 & $3 / 31 / 2010$ & 0913 & Environmental & 9.31 & .99 & .9 & -- & 4.29 & .46 & .49 & -- \\
\hline 295249095364701 & LJ-65-04-728 & $3 / 31 / 2010$ & 1113 & Environmental & 3.72 & .41 & .49 & -- & 2.84 & .52 & .78 & -- \\
\hline 295249095370701 & LJ-65-04-729 & $3 / 31 / 2010$ & 1228 & Environmental & 14.4 & 1.2 & .92 & -- & 3.73 & .42 & .45 & -- \\
\hline 295243095383101 & LJ-65-03-916 & $4 / 1 / 2010$ & 0941 & Environmental & 3.00 & .48 & .65 & -- & 3.66 & .49 & .62 & -- \\
\hline 294712095401301 & LJ-65-11-803 & $4 / 1 / 2010$ & 1124 & Environmental & 6.49 & .61 & .65 & -- & 3.20 & .53 & .76 & -- \\
\hline 294717095401001 & LJ-65-11-804 & $4 / 1 / 2010$ & 1229 & Environmental & 2.67 & .67 & .98 & -- & 3.07 & .45 & .57 & -- \\
\hline 294952095342601 & LJ-65-12-519 & $4 / 5 / 2010$ & 1030 & Environmental & 3.94 & .47 & 6 & -- & 2.96 & .53 & .76 & -- \\
\hline 294952095342601 & $L J-65-12-519$ & $4 / 5 / 2010$ & 1031 & $\begin{array}{l}\text { Sequential } \\
\text { replicate }\end{array}$ & 3.08 & .38 & .47 & -- & 3.50 & .41 & .49 & -- \\
\hline 294925095341201 & LJ-65-12-520 & $4 / 5 / 2010$ & 1202 & Environmental & 7.5 & 6 & .52 & -- & 3.66 & .42 & .5 & -- \\
\hline 294844095342401 & LJ-65-12-522 & $4 / 5 / 2010$ & 1338 & Environmental & 5.33 & .58 & .73 & -- & 3.24 & .38 & .46 & -- \\
\hline 294800095344101 & LJ-65-12-516 & $4 / 6 / 2010$ & 0920 & Environmental & 3.03 & .46 & 6 & -- & 2.68 & .45 & .6 & -- \\
\hline
\end{tabular}


Table 6. Results of radionuclide analyses of water samples collected from municipal supply wells in the Houston, Texas, area, 2010-Continued.

\begin{tabular}{|c|c|c|c|c|c|c|c|c|c|c|c|c|}
\hline $\begin{array}{l}\text { U.S. Geological Sur- } \\
\text { vey site number }\end{array}$ & $\begin{array}{l}\text { State well } \\
\text { number }\end{array}$ & Date & $\begin{array}{c}\text { Sample } \\
\text { start } \\
\text { time }\end{array}$ & Sample type & $\begin{array}{c}\text { Beta radio- } \\
\text { activity, 30- } \\
\text { day count, } \\
\text { water, } \\
\text { filtered, } \\
\text { Cs-137 } \\
\text { curve } \\
\text { (pCi/L) }\end{array}$ & $\begin{array}{c}\text { Beta radio- } \\
\text { activity, } 30- \\
\text { day count, } \\
\text { 1-sigma } \\
\text { CSU, water, } \\
\text { filtered, } \\
\text { Cs-137 curve } \\
\text { (pCi/L) }\end{array}$ & $\begin{array}{c}\text { Beta radio- } \\
\text { activity, 30- } \\
\text { day count, } \\
\text { ssLC, water, } \\
\text { filtered, } \\
\text { Cs-137 } \\
\text { curve } \\
\text { (pCi/L) }\end{array}$ & $\begin{array}{c}\text { Beta } \\
\text { radio- } \\
\text { activity, } \\
\text { 30-day } \\
\text { count } \\
\text { (remark } \\
\text { code) }\end{array}$ & $\begin{array}{c}\text { Beta } \\
\text { radioactiv- } \\
\text { ity, 72-hour } \\
\text { count, } \\
\text { water, } \\
\text { filtered, } \\
\text { Cs-137 curve } \\
\text { (pCi/L)' }\end{array}$ & $\begin{array}{c}\text { Beta radio- } \\
\text { activity, 72- } \\
\text { hour count, } \\
\text { 1-sigma CSU, } \\
\text { water, fil- } \\
\text { tered, Cs-137 } \\
\text { curve } \\
\text { (pCi/L) }\end{array}$ & $\begin{array}{l}\text { Beta radio- } \\
\text { activity, 72- } \\
\text { hour count, } \\
\text { ssL } \mathrm{c}^{\prime} \text {, water, } \\
\text { filtered, } \\
\text { Cs-137 } \\
\text { curve } \\
\text { (pCi/L) }\end{array}$ & $\begin{array}{c}\text { Beta } \\
\text { radio- } \\
\text { activity, } \\
\text { 72-hour } \\
\text { count } \\
\text { (remark } \\
\text { code) }\end{array}$ \\
\hline 294735095344001 & LJ-65-12-521 & $4 / 6 / 2010$ & 1042 & Environmental & 3.20 & 0.63 & 0.93 & -- & 3.22 & 0.52 & 0.72 & -- \\
\hline 294627095375801 & LJ-65-11-914 & $4 / 6 / 2010$ & 1216 & Environmental & 2.63 & .39 & .52 & -- & 2.61 & .39 & .51 & -- \\
\hline 294721095361001 & LJ-65-12-719 & 4/7/2010 & 0909 & Environmental & 3.42 & .49 & .66 & -- & 3.00 & .44 & .57 & -- \\
\hline 294723095370501 & LJ-65-12-730 & $4 / 7 / 2010$ & 1040 & Environmental & 2.48 & .35 & .45 & -- & 3.25 & .53 & .76 & -- \\
\hline 294723095382601 & LJ-65-11-920 & $4 / 7 / 2010$ & 1209 & Environmental & 2.94 & .39 & .5 & -- & 3.64 & .39 & .44 & -- \\
\hline 294731095414201 & LJ-65-11-514 & $4 / 8 / 2010$ & 1016 & Environmental & 1.17 & .47 & .73 & -- & 2.22 & .51 & .74 & -- \\
\hline 295553095191201 & LJ-65-06-528 & $4 / 8 / 2010$ & 1331 & Environmental & 1.76 & .32 & .46 & -- & 1.99 & .49 & .73 & -- \\
\hline 295027095312301 & LJ-65-12-328 & $5 / 6 / 2010$ & 0940 & Environmental & -- & -- & -- & -- & -- & -- & -- & -- \\
\hline 293636095300401 & JY-65-28-309 & $10 / 28 / 2010$ & 1011 & Environmental & 3.08 & .82 & 1.3 & -- & 3.69 & .63 & .83 & -- \\
\hline 293635095294101 & JY-65-29-107 & $10 / 28 / 2010$ & 1225 & Environmental & 3.47 & .63 & .91 & -- & 3.49 & .77 & 1.1 & -- \\
\hline 293652095293601 & LJ-65-29-108 & $10 / 28 / 2010$ & 1350 & Environmental & 3.42 & .92 & 1.3 & -- & 2.63 & .62 & .84 & -- \\
\hline 294252095362101 & LJ-65-20-125 & $11 / 3 / 2010$ & 1033 & Environmental & 3.89 & .68 & .92 & -- & 3.0 & .5 & .68 & $\mathrm{c}$ \\
\hline 294127095342502 & LJ-65-20-519 & $11 / 4 / 2010$ & 0945 & Environmental & 1.48 & .61 & .93 & -- & 2.42 & .52 & .8 & -- \\
\hline 294127095342502 & $L J-65-20-519$ & $11 / 4 / 2010$ & 0946 & $\begin{array}{l}\text { Sequential } \\
\text { replicate }\end{array}$ & 1.65 & .76 & 1.1 & -- & 1.82 & .51 & .77 & -- \\
\hline 294047095345601 & LJ-65-20-516 & $11 / 4 / 2010$ & 1114 & Environmental & 6.18 & .65 & .72 & -- & 3.68 & .54 & .72 & -- \\
\hline 294050095355501 & LJ-65-20-416 & $11 / 9 / 2010$ & 1159 & Environmental & 3.25 & .82 & 1.2 & -- & 2.59 & .67 & 1 & -- \\
\hline
\end{tabular}


Table 6. Results of radionuclide analyses of water samples collected from municipal supply wells in the Houston, Texas, area, 2010-Continued.

\begin{tabular}{|c|c|c|c|c|c|c|c|c|c|c|c|c|}
\hline $\begin{array}{l}\text { U.S. Geologi- } \\
\text { cal Survey site } \\
\text { number }\end{array}$ & $\begin{array}{l}\text { State well } \\
\text { number }\end{array}$ & Date & $\begin{array}{c}\text { Sample } \\
\text { start } \\
\text { time }\end{array}$ & Sample type & $\begin{array}{l}\text { Carbon-14 } \\
\text { counting } \\
\text { error, water, } \\
\text { filtered } \\
\text { (percent } \\
\text { modern) } \\
\end{array}$ & $\begin{array}{l}\text { Carbon-14, } \\
\text { water, } \\
\text { filtered } \\
\text { (percent } \\
\text { modern) }\end{array}$ & $\begin{array}{c}\text { Carbon-13/ } \\
\text { carbon-12 } \\
\text { ratio, water, } \\
\text { unfiltered } \\
\text { (per mil) }\end{array}$ & $\begin{array}{c}\text { Carbon-13/ } \\
\text { carbon-12 } \\
\text { ratio } \\
\text { (remark } \\
\text { code) }\end{array}$ & $\begin{array}{l}\text { Radium-226, } \\
\text { water, } \\
\text { filtered, } \\
\text { radon } \\
\text { method } \\
\text { (pCi/L) }\end{array}$ & $\begin{array}{l}\text { Radium-226, } \\
\text { 1-sigma } \\
\text { CSU, water, } \\
\text { filtered, ra- } \\
\text { don method } \\
\text { (pCi/L) }\end{array}$ & $\begin{array}{c}\text { Ra- } \\
\text { dium-226, } \\
\text { ssL } \mathrm{L}_{\mathrm{c}^{\prime}} \text { water, } \\
\text { filtered, ra- } \\
\text { don method } \\
\text { (pCi/L) }\end{array}$ & $\begin{array}{c}\text { Ra- } \\
\text { dium-226 } \\
\text { (remark } \\
\text { code) }\end{array}$ \\
\hline 294921095312907 & LJ-65-12-633 & $3 / 16 / 2010$ & 1041 & Environmental & -- & -- & -- & -- & -- & -- & -- & -- \\
\hline 294900095312101 & LJ-65-12-619 & $3 / 16 / 2010$ & 1257 & Environmental & -- & -- & -- & -- & -- & -- & -- & -- \\
\hline 295027095312301 & LJ-65-12-328 & $3 / 17 / 2010$ & 0927 & Environmental & -- & -- & -- & -- & -- & -- & -- & -- \\
\hline 295027095312301 & $L J-65-12-328$ & $3 / 17 / 2010$ & 0928 & $\begin{array}{l}\text { Sequential } \\
\quad \text { replicate }\end{array}$ & -- & -- & -- & -- & -- & -- & -- & -- \\
\hline 294950095313701 & LJ-65-12-622 & $3 / 17 / 2010$ & 1114 & Environmental & -- & -- & -- & -- & -- & -- & -- & -- \\
\hline 294340095311103 & LJ-65-20-321 & $3 / 18 / 2010$ & 0952 & Environmental & -- & -- & -- & -- & -- & -- & -- & -- \\
\hline 294348095303702 & LJ-65-20-319 & $3 / 18 / 2010$ & 1147 & Environmental & -- & -- & -- & -- & -- & -- & -- & -- \\
\hline 294348095270401 & LJ-65-21-202 & $3 / 22 / 2010$ & 1002 & Environmental & -- & -- & -- & -- & -- & -- & -- & -- \\
\hline 294338095270401 & LJ-65-21-201 & $3 / 22 / 2010$ & 1129 & Environmental & -- & -- & -- & -- & -- & -- & -- & -- \\
\hline 294333095275602 & LJ-65-21-143 & $3 / 22 / 2010$ & 1304 & Environmental & -- & -- & -- & -- & -- & -- & -- & -- \\
\hline 294329095284602 & LJ-65-21-148 & $3 / 23 / 2010$ & 1001 & Environmental & -- & -- & -- & -- & 0.732 & 0.069 & 0.026 & -- \\
\hline 294329095284602 & $L J-65-21-148$ & $3 / 23 / 2010$ & 1002 & $\begin{array}{l}\text { Sequential } \\
\quad \text { replicate }\end{array}$ & -- & -- & -- & -- & -- & -- & -- & -- \\
\hline 294319095305901 & LJ-65-20-303 & $3 / 23 / 2010$ & 1123 & Environmental & -- & -- & -- & -- & -- & -- & -- & -- \\
\hline 294317095313001 & LJ-65-20-304 & $3 / 23 / 2010$ & 1252 & Environmental & -- & -- & -- & -- & -- & -- & -- & -- \\
\hline 294328095290402 & LJ-65-21-149 & $3 / 24 / 2010$ & 1036 & Environmental & -- & -- & -- & -- & -- & -- & -- & -- \\
\hline 294323095300103 & LJ-65-20-325 & $3 / 24 / 2010$ & 1151 & Environmental & -- & -- & -- & -- & -- & -- & -- & -- \\
\hline 294201095355601 & LJ-65-20-405 & $3 / 24 / 2010$ & 1343 & Environmental & -- & -- & -- & -- & -- & -- & -- & -- \\
\hline 293732095300601 & LJ-65-20-911 & $3 / 25 / 2010$ & 0932 & Environmental & -- & -- & -- & -- & -- & -- & -- & -- \\
\hline
\end{tabular}


Table 6. Results of radionuclide analyses of water samples collected from municipal supply wells in the Houston, Texas, area, 2010-Continued.

\begin{tabular}{|c|c|c|c|c|c|c|c|c|c|c|c|c|}
\hline $\begin{array}{l}\text { U.S. Geologi- } \\
\text { cal Survey site } \\
\text { number }\end{array}$ & $\begin{array}{l}\text { State well } \\
\text { number }\end{array}$ & Date & $\begin{array}{c}\text { Sample } \\
\text { start } \\
\text { time }\end{array}$ & Sample type & $\begin{array}{c}\text { Carbon-14 } \\
\text { counting } \\
\text { error, water, } \\
\text { filtered } \\
\text { (percent } \\
\text { modern) }\end{array}$ & $\begin{array}{l}\text { Carbon-14, } \\
\text { water, } \\
\text { filtered } \\
\text { (percent } \\
\text { modern) }\end{array}$ & $\begin{array}{c}\text { Carbon-13/ } \\
\text { carbon-12 } \\
\text { ratio, water, } \\
\text { unfiltered } \\
\text { (per mil) }\end{array}$ & $\begin{array}{c}\text { Carbon-13/ } \\
\text { carbon-12 } \\
\text { ratio } \\
\text { (remark } \\
\text { code) }\end{array}$ & $\begin{array}{l}\text { Radium-226, } \\
\text { water, } \\
\text { filtered, } \\
\text { radon } \\
\text { method } \\
\text { (pCi/L) }\end{array}$ & $\begin{array}{l}\text { Radium-226, } \\
\text { 1-sigma } \\
\text { CSU, water, } \\
\text { filtered, ra- } \\
\text { don method } \\
\text { (pCi/L) }\end{array}$ & $\begin{array}{c}\text { Ra- } \\
\text { dium-226, } \\
\text { ssL }, \text { water, } \\
\text { filtered, ra- } \\
\text { don method } \\
\text { (pCi/L) }\end{array}$ & $\begin{array}{c}\text { Ra- } \\
\text { dium-226 } \\
\text { (remark } \\
\text { code) }\end{array}$ \\
\hline 293734095293701 & LJ-65-21-708 & $3 / 25 / 2010$ & 1130 & Environmental & -- & -- & -- & -- & -- & -- & -- & -- \\
\hline 293736095285301 & LJ-65-21-709 & $3 / 25 / 2010$ & 1257 & Environmental & -- & -- & -- & -- & -- & -- & -- & -- \\
\hline 294002095351001 & LJ-65-20-414 & $3 / 29 / 2010$ & 1108 & Environmental & -- & -- & -- & -- & -- & -- & -- & -- \\
\hline 294414095364202 & LJ-65-20-126 & $3 / 29 / 2010$ & 1313 & Environmental & -- & -- & -- & -- & -- & -- & -- & -- \\
\hline 294456095341101 & LJ-65-12-820 & $3 / 30 / 2010$ & 0906 & Environmental & -- & -- & -- & -- & -- & -- & -- & -- \\
\hline 294501095343601 & LJ-65-12-817 & $3 / 30 / 2010$ & 1021 & Environmental & -- & -- & -- & -- & -- & -- & -- & -- \\
\hline 294519095383201 & LJ-65-11-918 & $3 / 30 / 2010$ & 1154 & Environmental & -- & -- & -- & -- & -- & -- & -- & -- \\
\hline 295246095351301 & LJ-65-04-723 & $3 / 31 / 2010$ & 0913 & Environmental & -- & -- & -- & -- & -- & -- & -- & -- \\
\hline 295249095364701 & LJ-65-04-728 & $3 / 31 / 2010$ & 1113 & Environmental & -- & -- & -- & -- & -- & -- & -- & -- \\
\hline 295249095370701 & LJ-65-04-729 & $3 / 31 / 2010$ & 1228 & Environmental & -- & -- & -- & -- & -- & -- & -- & -- \\
\hline 295243095383101 & LJ-65-03-916 & $4 / 1 / 2010$ & 0941 & Environmental & -- & -- & -- & -- & 1.65 & 0.14 & 0.022 & -- \\
\hline 294712095401301 & LJ-65-11-803 & $4 / 1 / 2010$ & 1124 & Environmental & -- & -- & -- & -- & 2.23 & .19 & .025 & -- \\
\hline 294717095401001 & LJ-65-11-804 & $4 / 1 / 2010$ & 1229 & Environmental & -- & -- & -- & -- & 1.97 & .17 & .028 & -- \\
\hline 294952095342601 & LJ-65-12-519 & $4 / 5 / 2010$ & 1030 & Environmental & -- & -- & -- & -- & -- & -- & -- & -- \\
\hline 294952095342601 & LJ-65-12-519 & $4 / 5 / 2010$ & 1031 & $\begin{array}{l}\text { Sequential } \\
\quad \text { replicate }\end{array}$ & -- & -- & -- & -- & -- & -- & -- & -- \\
\hline 294925095341201 & LJ-65-12-520 & $4 / 5 / 2010$ & 1202 & Environmental & -- & -- & -- & -- & 2.59 & .22 & .026 & -- \\
\hline 294844095342401 & LJ-65-12-522 & $4 / 5 / 2010$ & 1338 & Environmental & -- & -- & -- & -- & 1.60 & .14 & .029 & -- \\
\hline
\end{tabular}


Table 6. Results of radionuclide analyses of water samples collected from municipal supply wells in the Houston, Texas, area, 2010-Continued.

\begin{tabular}{|c|c|c|c|c|c|c|c|c|c|c|c|c|}
\hline $\begin{array}{l}\text { U.S. Geologi- } \\
\text { cal Survey site } \\
\text { number }\end{array}$ & $\begin{array}{l}\text { State well } \\
\text { number }\end{array}$ & Date & $\begin{array}{c}\text { Sample } \\
\text { start } \\
\text { time }\end{array}$ & Sample type & $\begin{array}{l}\text { Carbon-14 } \\
\text { counting } \\
\text { error, water, } \\
\text { filtered } \\
\text { (percent } \\
\text { modern) }\end{array}$ & $\begin{array}{l}\text { Carbon-14, } \\
\text { water, } \\
\text { filtered } \\
\text { (percent } \\
\text { modern) }\end{array}$ & $\begin{array}{l}\text { Carbon-13/ } \\
\text { carbon-12 } \\
\text { ratio, water, } \\
\text { unfiltered } \\
\text { (per mil) }\end{array}$ & $\begin{array}{c}\text { Carbon-13/ } \\
\text { carbon-12 } \\
\text { ratio } \\
\text { (remark } \\
\text { code) }\end{array}$ & $\begin{array}{l}\text { Radium-226, } \\
\text { water, } \\
\text { filtered, } \\
\text { radon } \\
\text { method } \\
\text { (pCi/L) }\end{array}$ & $\begin{array}{c}\text { Radium-226, } \\
\text { 1-sigma } \\
\text { cSU, water, } \\
\text { filtered, ra- } \\
\text { don method } \\
\text { (pCi/L) }\end{array}$ & $\begin{array}{c}\text { Ra- } \\
\text { dium-226, } \\
\text { ssL } \mathrm{L}_{\mathrm{c}^{\prime}} \text { water, } \\
\text { filtered, ra- } \\
\text { don method } \\
\text { (pCi/L) }\end{array}$ & $\begin{array}{c}\text { Ra- } \\
\text { dium-226 } \\
\text { (remark } \\
\text { code) }\end{array}$ \\
\hline 294800095344101 & LJ-65-12-516 & $4 / 6 / 2010$ & 0920 & Environmental & -- & -- & -- & -- & -- & -- & -- & -- \\
\hline 294735095344001 & LJ-65-12-521 & $4 / 6 / 2010$ & 1042 & Environmental & -- & -- & -- & -- & -- & -- & -- & -- \\
\hline 294627095375801 & LJ-65-11-914 & $4 / 6 / 2010$ & 1216 & Environmental & -- & -- & -- & -- & -- & -- & -- & -- \\
\hline 294721095361001 & LJ-65-12-719 & $4 / 7 / 2010$ & 0909 & Environmental & -- & -- & -- & -- & -- & -- & -- & -- \\
\hline 294723095370501 & LJ-65-12-730 & 4/7/2010 & 1040 & Environmental & -- & -- & -- & -- & -- & -- & -- & -- \\
\hline 294723095382601 & LJ-65-11-920 & $4 / 7 / 2010$ & 1209 & Environmental & -- & -- & -- & -- & -- & -- & -- & -- \\
\hline 294731095414201 & LJ-65-11-514 & $4 / 8 / 2010$ & 1016 & Environmental & -- & -- & -- & -- & -- & -- & -- & -- \\
\hline 295553095191201 & LJ-65-06-528 & $4 / 8 / 2010$ & 1331 & Environmental & -- & -- & -- & -- & -- & -- & -- & -- \\
\hline 295027095312301 & LJ-65-12-328 & $5 / 6 / 2010$ & 0940 & Environmental & 0.02 & 0.20 & -12.71 & -- & -- & -- & -- & -- \\
\hline 293636095300401 & JY-65-28-309 & $10 / 28 / 2010$ & 1011 & Environmental & -- & -- & -- & -- & -- & -- & -- & -- \\
\hline 293635095294101 & JY-65-29-107 & $10 / 28 / 2010$ & 1225 & Environmental & -- & -- & -- & -- & -- & -- & -- & -- \\
\hline 293652095293601 & LJ-65-29-108 & $10 / 28 / 2010$ & 1350 & Environmental & -- & -- & -- & -- & -- & -- & -- & -- \\
\hline 294252095362101 & LJ-65-20-125 & $11 / 3 / 2010$ & 1033 & Environmental & -- & -- & -- & -- & -- & -- & -- & -- \\
\hline 294127095342502 & LJ-65-20-519 & $11 / 4 / 2010$ & 0945 & Environmental & -- & -- & -- & -- & -- & -- & -- & -- \\
\hline 294127095342502 & $L J-65-20-519$ & $11 / 4 / 2010$ & 0946 & $\begin{array}{l}\text { Sequential } \\
\quad \text { replicate }\end{array}$ & -- & -- & -- & -- & -- & -- & -- & -- \\
\hline 294047095345601 & LJ-65-20-516 & $11 / 4 / 2010$ & 1114 & Environmental & -- & -- & -- & -- & -- & -- & -- & -- \\
\hline 294050095355501 & LJ-65-20-416 & $11 / 9 / 2010$ & 1159 & Environmental & -- & -- & -- & -- & -- & -- & -- & -- \\
\hline
\end{tabular}


Table 6. Results of radionuclide analyses of water samples collected from municipal supply wells in the Houston, Texas, area, 2010-Continued.

\begin{tabular}{|c|c|c|c|c|c|c|c|c|c|c|c|c|}
\hline $\begin{array}{l}\text { U.S. Geological } \\
\text { Survey site number }\end{array}$ & $\begin{array}{l}\text { State well } \\
\text { number }\end{array}$ & Date & $\begin{array}{c}\text { Sample } \\
\text { start } \\
\text { time }\end{array}$ & Sample type & $\begin{array}{c}\text { Radon-222, } \\
\text { water, } \\
\text { unfiltered } \\
\text { (pCi/L) }\end{array}$ & $\begin{array}{l}\text { Radon-222, } \\
\text { 1-sigma } \\
\text { CSU, water, } \\
\text { unfiltered } \\
\text { (pCi/L) }\end{array}$ & $\begin{array}{c}\text { Radon-222, } \\
\text { ss } \mathrm{L}_{\mathrm{c}^{\prime}} \text { water, } \\
\text { unfiltered } \\
\text { (pCi/L) }\end{array}$ & $\begin{array}{c}\text { Radon-222 } \\
\text { (remark } \\
\text { code) }\end{array}$ & $\begin{array}{c}\text { Uranium } \\
\text { (natural), } \\
\text { water, } \\
\text { filtered } \\
\text { ( } \mu \mathrm{g} / \mathrm{L})\end{array}$ & $\begin{array}{l}\text { Uranium } \\
\text { (natural), } \\
\text { LRL, water, } \\
\text { filtered } \\
\text { ( } \mu \mathrm{g} / \mathrm{L})\end{array}$ & $\begin{array}{c}\text { Uranium } \\
\text { (natural), } \\
\text { LT-MDL, } \\
\text { water, filtered } \\
\text { ( } \mu \mathrm{g} / \mathrm{L})\end{array}$ & $\begin{array}{c}\text { Uranium } \\
\text { (natural) } \\
\text { (remark } \\
\text { code) }\end{array}$ \\
\hline 294921095312907 & LJ-65-12-633 & $3 / 16 / 2010$ & 1041 & Environmental & -- & -- & -- & -- & 3.78 & 0.008 & -- & -- \\
\hline 294900095312101 & LJ-65-12-619 & $3 / 16 / 2010$ & 1257 & Environmental & -- & -- & -- & -- & 4.01 & .008 & -- & -- \\
\hline 295027095312301 & LJ-65-12-328 & $3 / 17 / 2010$ & 0927 & Environmental & -- & -- & -- & -- & .32 & .008 & -- & -- \\
\hline 295027095312301 & $L J-65-12-328$ & $3 / 17 / 2010$ & 0928 & $\begin{array}{l}\text { Sequential } \\
\quad \text { replicate }\end{array}$ & -- & -- & -- & -- & .32 & .008 & -- & -- \\
\hline 294950095313701 & LJ-65-12-622 & $3 / 17 / 2010$ & 1114 & Environmental & -- & -- & -- & -- & 11.9 & .008 & -- & -- \\
\hline 294340095311103 & LJ-65-20-321 & $3 / 18 / 2010$ & 0952 & Environmental & -- & -- & -- & -- & 1.72 & .008 & -- & -- \\
\hline 294348095303702 & LJ-65-20-319 & $3 / 18 / 2010$ & 1147 & Environmental & -- & -- & -- & -- & 2.59 & .008 & -- & -- \\
\hline 294348095270401 & LJ-65-21-202 & $3 / 22 / 2010$ & 1002 & Environmental & -- & -- & -- & -- & .38 & .008 & -- & -- \\
\hline 294338095270401 & LJ-65-21-201 & $3 / 22 / 2010$ & 1129 & Environmental & -- & -- & -- & -- & 8.14 & .008 & -- & -- \\
\hline 294333095275602 & LJ-65-21-143 & $3 / 22 / 2010$ & 1304 & Environmental & -- & -- & -- & -- & 1.69 & .008 & -- & -- \\
\hline 294329095284602 & LJ-65-21-148 & $3 / 23 / 2010$ & 1001 & Environmental & -- & -- & -- & -- & 6.48 & .008 & -- & -- \\
\hline 294329095284602 & $L J-65-21-148$ & $3 / 23 / 2010$ & 1002 & $\begin{array}{l}\text { Sequential } \\
\quad \text { replicate }\end{array}$ & -- & -- & -- & -- & 6.50 & .008 & -- & -- \\
\hline 294319095305901 & LJ-65-20-303 & $3 / 23 / 2010$ & 1123 & Environmental & -- & -- & -- & -- & 7.82 & .008 & -- & -- \\
\hline 294317095313001 & LJ-65-20-304 & $3 / 23 / 2010$ & 1252 & Environmental & -- & -- & -- & -- & 1.40 & .008 & -- & -- \\
\hline 294328095290402 & LJ-65-21-149 & $3 / 24 / 2010$ & 1036 & Environmental & -- & -- & -- & -- & 6.96 & .008 & -- & -- \\
\hline 294323095300103 & LJ-65-20-325 & $3 / 24 / 2010$ & 1151 & Environmental & -- & -- & -- & -- & 1.21 & .008 & -- & -- \\
\hline 294201095355601 & LJ-65-20-405 & $3 / 24 / 2010$ & 1343 & Environmental & -- & -- & -- & -- & 6.94 & .008 & -- & -- \\
\hline
\end{tabular}




\begin{tabular}{|c|c|c|c|c|c|c|c|c|c|c|c|c|}
\hline $\begin{array}{l}\text { U.S. Geological } \\
\text { Survey site number }\end{array}$ & $\begin{array}{l}\text { State well } \\
\text { number }\end{array}$ & Date & $\begin{array}{c}\text { Sample } \\
\text { start } \\
\text { time }\end{array}$ & Sample type & $\begin{array}{c}\text { Radon-222, } \\
\text { water, } \\
\text { unfiltered } \\
\text { (pCi/L) }\end{array}$ & $\begin{array}{l}\text { Radon-222, } \\
\text { 1-sigma } \\
\text { CSU, water, } \\
\text { unfiltered } \\
\text { (pCi/L) }\end{array}$ & $\begin{array}{c}\text { Radon-222, } \\
\text { ssL } \mathrm{L}_{c} \text {, water, } \\
\text { unfiltered } \\
\text { (pCi/L) }\end{array}$ & $\begin{array}{c}\text { Radon-222 } \\
\text { (remark } \\
\text { code) }\end{array}$ & $\begin{array}{c}\text { Uranium } \\
\text { (natural), } \\
\text { water, } \\
\text { filtered } \\
\text { ( } \mu \mathrm{g} / \mathrm{L})\end{array}$ & $\begin{array}{l}\text { Uranium } \\
\text { (natural), } \\
\text { LRL, water, } \\
\text { filtered } \\
\text { ( } \mu \mathrm{g} / \mathrm{L})\end{array}$ & $\begin{array}{c}\text { Uranium } \\
\text { (natural), } \\
\text { LT-MDL, } \\
\text { water, filtered } \\
\text { ( } \mu \mathrm{g} / \mathrm{L})\end{array}$ & $\begin{array}{c}\text { Uranium } \\
\text { (natural) } \\
\text { (remark } \\
\text { code) }\end{array}$ \\
\hline 293732095300601 & LJ-65-20-911 & $3 / 25 / 2010$ & 0932 & Environmental & -- & -- & -- & -- & 7.04 & 0.008 & -- & -- \\
\hline 293734095293701 & LJ-65-21-708 & $3 / 25 / 2010$ & 1130 & Environmental & -- & -- & -- & -- & 4.56 & .008 & -- & -- \\
\hline 293736095285301 & LJ-65-21-709 & $3 / 25 / 2010$ & 1257 & Environmental & -- & -- & -- & -- & 6.40 & .008 & -- & -- \\
\hline 294002095351001 & LJ-65-20-414 & $3 / 29 / 2010$ & 1108 & Environmental & -- & -- & -- & -- & 17.5 & .008 & -- & -- \\
\hline 294414095364202 & LJ-65-20-126 & $3 / 29 / 2010$ & 1313 & Environmental & -- & -- & -- & -- & .27 & .008 & -- & -- \\
\hline 294456095341101 & LJ-65-12-820 & $3 / 30 / 2010$ & 0906 & Environmental & -- & -- & -- & -- & 3.67 & .008 & -- & -- \\
\hline 294501095343601 & LJ-65-12-817 & $3 / 30 / 2010$ & 1021 & Environmental & -- & -- & -- & -- & 3.92 & .008 & -- & -- \\
\hline 294519095383201 & LJ-65-11-918 & $3 / 30 / 2010$ & 1154 & Environmental & -- & -- & -- & -- & 3.91 & .008 & -- & -- \\
\hline 295246095351301 & LJ-65-04-723 & $3 / 31 / 2010$ & 0913 & Environmental & -- & -- & -- & -- & 23.2 & .008 & -- & -- \\
\hline 295249095364701 & LJ-65-04-728 & $3 / 31 / 2010$ & 1113 & Environmental & -- & -- & -- & -- & .80 & .008 & -- & -- \\
\hline 295249095370701 & LJ-65-04-729 & $3 / 31 / 2010$ & 1228 & Environmental & -- & -- & -- & -- & 42.7 & .008 & -- & -- \\
\hline 295243095383101 & LJ-65-03-916 & $4 / 1 / 2010$ & 0941 & Environmental & -- & -- & -- & -- & .56 & .008 & -- & -- \\
\hline 294712095401301 & LJ-65-11-803 & $4 / 1 / 2010$ & 1124 & Environmental & -- & -- & -- & -- & 1.76 & .008 & -- & -- \\
\hline 294717095401001 & LJ-65-11-804 & $4 / 1 / 2010$ & 1229 & Environmental & -- & -- & -- & -- & .73 & .008 & -- & -- \\
\hline 294952095342601 & LJ-65-12-519 & $4 / 5 / 2010$ & 1030 & Environmental & -- & -- & -- & -- & 2.36 & .008 & -- & -- \\
\hline 294952095342601 & $L J-65-12-519$ & $4 / 5 / 2010$ & 1031 & $\begin{array}{l}\text { Sequential } \\
\quad \text { replicate }\end{array}$ & -- & -- & -- & -- & 2.43 & .008 & -- & -- \\
\hline 294925095341201 & LJ-65-12-520 & $4 / 5 / 2010$ & 1202 & Environmental & -- & -- & -- & -- & .12 & .008 & -- & -- \\
\hline 294844095342401 & LJ-65-12-522 & $4 / 5 / 2010$ & 1338 & Environmental & -- & -- & -- & -- & .32 & .008 & -- & -- \\
\hline
\end{tabular}


Table 6. Results of radionuclide analyses of water samples collected from municipal supply wells in the Houston, Texas, area, 2010-Continued.

\begin{tabular}{|c|c|c|c|c|c|c|c|c|c|c|c|c|}
\hline $\begin{array}{l}\text { U.S. Geological } \\
\text { Survey site number }\end{array}$ & $\begin{array}{c}\text { State well } \\
\text { number }\end{array}$ & Date & $\begin{array}{c}\text { Sample } \\
\text { start } \\
\text { time }\end{array}$ & Sample type & $\begin{array}{c}\text { Radon-222, } \\
\text { water, } \\
\text { unfiltered } \\
\text { (pCi/L) }\end{array}$ & $\begin{array}{l}\text { Radon-222, } \\
\text { 1-sigma } \\
\text { CSU, water, } \\
\text { unfiltered } \\
\text { (pCi/L) }\end{array}$ & $\begin{array}{c}\text { Radon-222, } \\
\text { ssL }_{\mathrm{c}^{\prime}} \text { water, } \\
\text { unfiltered } \\
\text { (pCi/L) }\end{array}$ & $\begin{array}{c}\text { Radon-222 } \\
\text { (remark } \\
\text { code) }\end{array}$ & $\begin{array}{c}\text { Uranium } \\
\text { (natural), } \\
\text { water, } \\
\text { filtered } \\
\text { ( } \mu \mathrm{g} / \mathrm{L} \text { ) }\end{array}$ & $\begin{array}{l}\text { Uranium } \\
\text { (natural), } \\
\text { LRL, water, } \\
\text { filtered } \\
\text { ( } \mu \mathrm{g} / \mathrm{L})\end{array}$ & $\begin{array}{c}\text { Uranium } \\
\text { (natural), } \\
\text { LT-MDL, } \\
\text { water, filtered } \\
\text { ( } \mathrm{gg} / \mathrm{L})\end{array}$ & $\begin{array}{c}\text { Uranium } \\
\text { (natural) } \\
\text { (remark } \\
\text { code) }\end{array}$ \\
\hline 294800095344101 & LJ-65-12-516 & $4 / 6 / 2010$ & 0920 & Environmental & -- & -- & -- & -- & 0.90 & 0.008 & -- & -- \\
\hline 294735095344001 & LJ-65-12-521 & $4 / 6 / 2010$ & 1042 & Environmental & -- & -- & -- & -- & .38 & .008 & -- & -- \\
\hline 294627095375801 & LJ-65-11-914 & $4 / 6 / 2010$ & 1216 & Environmental & -- & -- & -- & -- & .38 & .008 & -- & -- \\
\hline 294721095361001 & LJ-65-12-719 & 4/7/2010 & 0909 & Environmental & -- & -- & -- & -- & 4.03 & .008 & -- & -- \\
\hline 294723095370501 & LJ-65-12-730 & $4 / 7 / 2010$ & 1040 & Environmental & -- & -- & -- & -- & 1.23 & .008 & -- & -- \\
\hline 294723095382601 & LJ-65-11-920 & $4 / 7 / 2010$ & 1209 & Environmental & -- & -- & -- & -- & .45 & .008 & -- & -- \\
\hline 294731095414201 & LJ-65-11-514 & $4 / 8 / 2010$ & 1016 & Environmental & -- & -- & -- & -- & .30 & .008 & -- & -- \\
\hline 295553095191201 & LJ-65-06-528 & $4 / 8 / 2010$ & 1331 & Environmental & -- & -- & -- & -- & .15 & .008 & -- & -- \\
\hline 295027095312301 & LJ-65-12-328 & $5 / 6 / 2010$ & 0940 & Environmental & -- & -- & -- & -- & .29 & .008 & -- & -- \\
\hline 293636095300401 & JY-65-28-309 & $10 / 28 / 2010$ & 1011 & Environmental & 1,700 & 94 & 12.004 & -- & 1.80 & -- & 0.004 & -- \\
\hline 293635095294101 & JY-65-29-107 & $10 / 28 / 2010$ & 1225 & Environmental & 1,620 & 90 & 11.963 & -- & 1.62 & -- & .004 & -- \\
\hline 293652095293601 & LJ-65-29-108 & $10 / 28 / 2010$ & 1350 & Environmental & 2,380 & 130 & 11.988 & -- & 3.88 & -- & .004 & -- \\
\hline 294252095362101 & LJ-65-20-125 & $11 / 3 / 2010$ & 1033 & Environmental & -- & -- & -- & -- & 7.58 & -- & .004 & -- \\
\hline 294127095342502 & LJ-65-20-519 & $11 / 4 / 2010$ & 0945 & Environmental & -- & -- & -- & -- & .03 & -- & .004 & -- \\
\hline 294127095342502 & $L J-65-20-519$ & $11 / 4 / 2010$ & 0946 & $\begin{array}{l}\text { Sequential } \\
\quad \text { replicate }\end{array}$ & -- & -- & -- & -- & .03 & -- & .004 & -- \\
\hline 294047095345601 & LJ-65-20-516 & $11 / 4 / 2010$ & 1114 & Environmental & -- & -- & -- & -- & 12.6 & -- & .004 & -- \\
\hline 294050095355501 & LJ-65-20-416 & $11 / 9 / 2010$ & 1159 & Environmental & -- & -- & -- & -- & 3.99 & -- & .004 & -- \\
\hline
\end{tabular}


Table 7. Relative percent differences (RPD) between sequential replicate and environmental samples analyzed for major ions, trace elements, and radionuclides and collected in association with municipal supply wells sampled in the Houston, Texas, area, 2010.

[RPDs are percentages; mg/L, milligrams per liter; $\mathrm{CaCO}_{3}$, calcium carbonate; $\mathrm{SiO}_{2}$, silicon dioxide; ${ }^{\circ} \mathrm{C}$, degrees Celsius; $\mu \mathrm{g} / \mathrm{L}$, micrograms per liter; $\mathrm{Th}$, thorium; $\mathrm{pCi} / \mathrm{L}$, picocuries per liter; $\mathrm{Cs}$, cesium; N/A, not applicable]

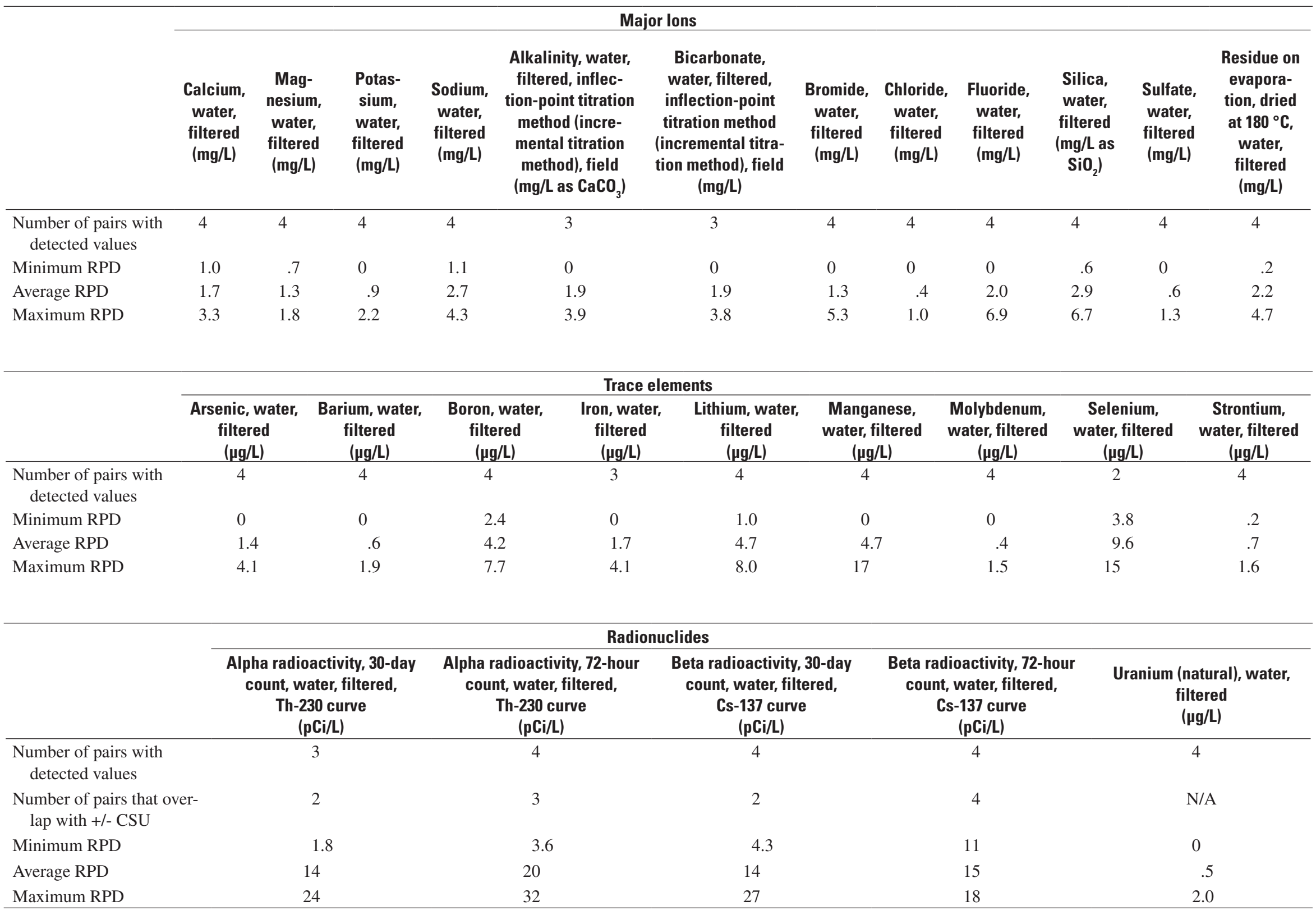

imum RPD 
Publishing support provided by Lafayette Publishing Service Center

Information regarding water resources in Texas is available at http://tx.usgs.gov/ 
